Illinois State University

ISU ReD: Research and eData

Theses and Dissertations

4-13-2014

\title{
To Thine Own Self Be Cruel: An Analysis of the Use of Self- Deprecating Humor as a Rhetorical Strategy by Figures in Positions of Authority
}

Brian Sorenson

Illinois State University, b_sorenson@comcast.net

Follow this and additional works at: https://ir.library.illinoisstate.edu/etd

Part of the Communication Commons, Political Science Commons, and the Rhetoric Commons

\section{Recommended Citation}

Sorenson, Brian, "To Thine Own Self Be Cruel: An Analysis of the Use of Self-Deprecating Humor as a Rhetorical Strategy by Figures in Positions of Authority" (2014). Theses and Dissertations. 129.

https://ir.library.illinoisstate.edu/etd/129

This Thesis is brought to you for free and open access by ISU ReD: Research and eData. It has been accepted for inclusion in Theses and Dissertations by an authorized administrator of ISU ReD: Research and eData. For more information, please contact ISUReD@ilstu.edu. 
TO THINE OWN SELF BE CRUEL: AN ANALYSIS OF THE USE OF SELFDEPRECATING HUMOR AS A RHETORICAL STRATEGY BY FIGURES IN POSITIONS OF AUTHORITY

\author{
Brian C. Sorenson
}

161 Pages

May 2014

This thesis analyzes the use of self-deprecating humor as a rhetorical strategy by figures in positions of authority. A close textual analysis was performed on eight White House Correspondents' Dinner speeches by U.S. presidents. Two speeches were analyzed from each of the four chosen presidents. The presidents whose respective uses of selfdeprecating humor were analyzed are Ronald Reagan, Bill Clinton, George W. Bush, and Barack Obama. Throughout each of the eight speeches analyzed, it was found that selfdeprecating humor can be used for multiple rhetorical purposes, including to defend against attacks, to bolster an image, and to attack others while maintaining perceived benevolence. 

TO THINE OWN SELF BE CRUEL: AN ANALYSIS OF THE USE OF SELFDEPRECATING HUMOR AS A RHETORICAL STRATEGY BY

FIGURES IN POSITIONS OF AUTHORITY

BRIAN C. SORENSON

A Thesis Submitted in Partial

Fulfillment of the Requirements for the Degree of

MASTER OF SCIENCE

School of Communication

ILLINOIS STATE UNIVERSITY

2014 


\begin{abstract}
All rights reserved
INFORMATION TO ALL USERS

The quality of this reproduction is dependent upon the quality of the copy submitted.

In the unlikely event that the author did not send a complete manuscript and there are missing pages, these will be noted. Also, if material had to be removed, a note will indicate the deletion.
\end{abstract}

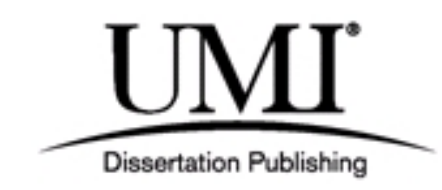

UMI 1562503

Published by ProQuest LLC (2014). Copyright in the Dissertation held by the Author.

Microform Edition (c) ProQuest LLC.

All rights reserved. This work is protected against unauthorized copying under Title 17, United States Code

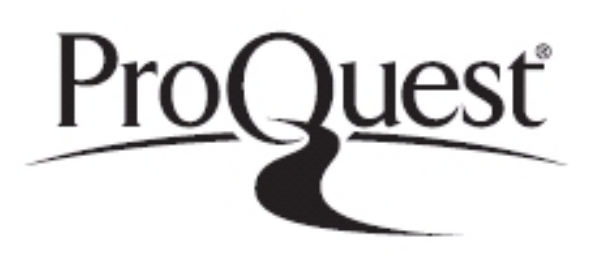

ProQuest LLC.

789 East Eisenhower Parkway

P.O. Box 1346

Ann Arbor, Ml $48106-1346$ 
(C) 2014 Brian C. Sorenson 
TO THINE OWN SELF BE CRUEL: AN ANALYSIS OF THE USE OF SELFDEPRECATING HUMOR AS A RHETORICAL STRATEGY BY

FIGURES IN POSITIONS OF AUTHORITY

BRIAN C. SORENSON

COMMITTEE MEMBERS:

Joseph P. Zompetti, Chair

Lance R. Lippert

Stephen K. Hunt 


\section{ACKNOWLEDGEMENTS}

This thesis would not have been possible were it not for the wisdom, guidance, and profound patience of a great many people, not the least of which being my committee chairman, Dr. Joseph Zompetti. Dr. Z's ability to rein in my topic from an abstract thought into something concrete worth analyzing has been crucial. I would also like to thank Dr. Lance Lippert, whose contributions of large mugs of coffee and abundant "dad jokes" during our Thursday morning meetings worked to make even the most dower mornings brighter. Dr. Stephen Hunt has also served as a tremendous inspiration. His sincere passion for teaching and overall enthusiasm for engagement is infectious. Fire it

up. Finally, a special thanks goes out to soon-to-be Dr. Chad Woolard. Chad's eagerness to help myself and any other graduate student in the office has been not only incredibly helpful, but tremendously inspiring as well. 


\section{CONTENTS}

Page

ACKNOWLEDGEMENTS $\quad$ i

$\begin{array}{ll}\text { CONTENTS } & \text { ii }\end{array}$

\section{CHAPTER}

I. INTRODUCTION 1

II. REVIEW OF RELATED LITERATURE 7

The Art of Rhetoric $\quad 8$

Ethos and Image $\quad 8$

Authority 12

Goodwill 14

Identification $\quad 16$

Rhetorical Situation $\quad 16$

$\begin{array}{ll}\text { Epideictic Rhetoric } & 17\end{array}$

$\begin{array}{ll}\text { Social Stratification } & 19\end{array}$

Social Stratification in Organizations $\quad 21$

Humor as a Unifier $\quad 22$

$\begin{array}{ll}\text { Humor } & 23\end{array}$

Humor as Persuasion $\quad 23$

Theories of Humor 24

Incongruence Theory $\quad 24$

Superiority Theory 26

Relief Theory $\quad 29$ 
$\begin{array}{ll}\text { Political Humor } & 32\end{array}$

Political Humor and Persuasion 32

White House Correspondents' Dinner 33

Self-Deprecating Humor $\quad 34$

Self-Deprecating Humor as a Rhetorical Strategy $\quad 35$

Self-Deprecating Humor in Practice 35

$\begin{array}{ll}\text { Conclusion } & 39\end{array}$

III. METHODOLOGY 41

White House Correspondents' Dinners Analyzed 42

Reagan $\quad 42$

Clinton 43

Bush 43

Obama 44

Close Textual Analysis $\quad 44$

Self-Deprecating Humor 45

Self-Deprecating Humor as Rhetorical Ironic Discourse 45

Superiority Theory of Humor and Humor as a Game 46

$\begin{array}{ll}\text { Method } & 47\end{array}$

Presidential Image $\quad 47$

Self-Deprecating Humor Operationalized $\quad 48$

The Rhetorical Situation $\quad 49$

$\begin{array}{lr}\text { Conclusion } & 50\end{array}$

$\begin{array}{ll}\text { IV. ANALYSIS } & 52\end{array}$

Introduction $\quad 52$

White House Correspondents' Dinner 53

Why White House Correspondents' Dinners? 53

iii 
The White House Correspondents' Association \& History of the Dinners 54

The White House Correspondents' Dinner as an

Epideictic Situation

The Presidents and their Speeches 56

Ronald Walker Reagan (1981-1984, 1985-1989) 57

April 13, 1984

April 17, 1986

William Jefferson Clinton (1993-1996, 1997-2000) 83

April 23, $1994 \quad 86$

April 29, $2000 \quad 100$

George Walker Bush (2001-2004, 2005-2008) 109

April 28, 2001

April 29, 2006

Barrack Hussein Obama (2009-2012, 2013) 124

April 30, 2011

April 27, 2013

The Everyman President 137

$\begin{array}{ll}\text { V. CONCLUSIONS } & 139\end{array}$

Limitations of the Analysis 144

Areas for Future Research 145

Conclusion 147

$\begin{array}{ll}\text { REFERENCES } & 149\end{array}$ 


\section{CHAPTER I}

\section{INTRODUCTION}

Humor is, in many ways, a universal language. Though the precise types of humor a given people may appreciate can vary by culture and geographic location, it is not a stretch to say that humor, at its very core, is a common human expression no less nuanced and multifaceted than any other universal communicative expression. As Lefcourt (2001) contends, "there is enough evidence to assert that our capacity for humor is an inherent characteristic of our species" (p. 53). It is this ubiquity and global appreciation of humor that makes it such a wellspring from which kinship and harmony are drawn and spread among all receivers. For, after all, what better way is there to ingratiate oneself to others, to truly bond, than to share in that which all in a community, irrespective of socioeconomic or other dichotomizing factor, can enjoy? Biebel (2010), quoting Castillo on the unifying power of humor, suggests that "the comic perspective is the one most conducive to productive deliberation between opponents who hold values that are conflicting” (para. 3). From primitive songs sung by campfires to discussions on present day Internet message boards, individuals seek to facilitate the creation of an inclusive environment in which to share thoughts — a leveled playing field, if you will—for those of all stripes.

Of such individuals, it is perhaps the authoritative rhetor more than anyone who 
desires to create for their audience such an environment, and it is no surprise then that humor, powerful harmonizing agent as it is, is an instrumental part of many successful persuasion attempts in this realm. Drawing on a common ground between speaker and audience, Duarte (2012) affirms, is essential for effective persuasion, submitting that one should "Figure out where you have common ground, and communicate on that frequency. Think about what's inside them that's also inside you. That way, you're not pushing or pulling them; they're moving because you tapped into something they already believe" (p. 21). Wielded with a deft touch in the hands of a skilled rhetor, humor can be a powerful tool with which one may make a strong persuasive appeal. Like clay in the hands of a sculptor, humor can take many forms and can be molded in such a way as to convey a great deal of meaning. As Smith (1993) asserts, humor is "one of the more effective means of argument and persuasion in popular culture" (p. 51). Truly, the sheer breadth of humor's potential grants it tremendous value and makes it a subject well worth assessing, particularly in the context of its use as a rhetorical strategy.

It is in this context that I wish to assess humor as it is employed to increase a rhetor's ethos by emphasizing common ground between themselves and audience. Humor's potential to unify, I submit, makes it a tremendous tool which, if used effectively, can enhance a rhetor's character. Yet scholarship on humor as an ethosbolstering tool is already abundant (Booth, 2007; Duarte, 2012; Gruner, 1985; Markiewicz, 1974; Smith, 1993). Thus, I aim to consider instead a particular subset of humor, for which existing scholarship is lacking, that of the self-deprecating variety.

To be sure, self-deprecating humor stands as an especially intriguing form of humor-as-rhetorical-argument when one considers its seemingly contradictory nature as a 
rhetorical strategy, perhaps explaining its relative dearth of representation among humor research. Self-deprecation, by its very nature, implies a belittling or disparagement of oneself (Rancer \& Graham, 2012, p. 14). Yet a rhetor's intended outcome of the use of self-deprecating humor is often in actuality a bolstering of one's image or argument (Dewberry \& Fox, 2012). Indeed, the use of self-deprecation can be fraught with risks of undermining the very credibility that the rhetor aims to raise (Bekelja, Frymier, Wojtaszczyk, \& Smith, 2006; Hackman, 1988). Thus, self-deprecating humor becomes something of a powder keg, its use risky and volatile, and so the apparent paradox of the use of this ostensibly credibility-lessening humor is apparent. Yet appropriate selfdeprecating humor is indeed what happens; one need not look far to hear of individuals who run the gamut from celebrities (Strecker, 2013), politicians (Tillman, 2012), and even religious leaders (Brown, 2012) who make use of this brand of humor, giving ample proof to the litany of situations in which the genre of humor's rhetorical efficacy is tested, in a wide range of contexts and situations, on its audience. This raises a series of questions for which I believe there has yet to be adequate answers in existing scholarship around which I shall perform my analysis: how can a rhetor effectively use selfdeprecating humor as a strategy to achieve a rhetorical outcome? When does the use of self-deprecating humor become inappropriate or serve to undermine rhetor credibility? In which situations is the use of self-deprecating humor most likely to succeed as a rhetorical strategy? And finally, for whom is self-deprecating humor most successful?

In this thesis, I will make the argument that such self-deprecating humor, used sparingly and as an additional strategy concurrently with other, well-established rhetorical strategies, can create a social leveling effect which can enhance a rhetorical 
appeal or persuasive attempt when appropriated by individuals who are perceived to be figures of authority. The use of this strategy, I propose, lessens the distance based on social standing, education, income, experience, or other stratifying quality that individuals may recognize between themselves and a speaker. Moreover, I suggest that self-deprecating humor can be evoked to instill a feeling of levity to assuage feelings of nervousness or unease that may exist in an audience in situations where the perceived social gulf between speaker and audience is large. Finally, I believe that self-deprecating humor, though ostensibly self-oriented, can also itself be used as an argument or to attack others as well.

I posit that those who use self-deprecating humor do so to create an environment in which the credibility of a rhetor is illustrated while also attempting to skirt any negative associations that may exist in the minds of an audience when thinking of the concept of authority (perceptions of arrogance, condescension, cavalierness, an imbalance of power, feelings of intimidation, and so on). In essence, this rhetorical process allows for the dual function of both sustaining the rhetor's position as a figure of authority while concurrently establishing a level of goodwill which increases rhetor approachability. To that end, I equate this rhetorical process with that of biological homeostasis, the process by which the body works to regulate its internal environment in order to maintain balance (Monosson, 2010). Thus, I will suggest that this process is something resembling rhetorical homeostasis, as so too must a rhetor in a position of authority be ever aware of perceived imbalances — in this case, social ones — and, when they exist, work to bring about equilibrium. Finally, I suggest that self-deprecation functions for individuals in a position of authority differently than it would for others; 
this is so, I will suggest, because authority figures already possess a deal of perceived credibility which results from their title, position, known history, or other authorityaffirming characteristic which an audience would already recognize as suggesting credibility all before word one leaves the rhetor's mouth.

To analyze the use of self-deprecating humor as a rhetorical strategy by those holding a position of authority, it is prudent to identify a situation in which selfdeprecating humor is employed on a consistent basis. The reason for this is simple: a situation in which the form of humor is regularly appropriated as a means of rhetorical discourse implies that it is not merely a rhetorical tool unique to a select few, but rather is one that is viewed as universally useful. Consequently, if we recognize such a consistent situation, we will be able to identify recurring themes in its use.

As we will find, self-deprecating humor can and is used by individuals in rhetorical situations of all stripes, irrespective of the nature of the position of the authority they hold. Yet of all recorded instances of self-deprecating humor employed by figures of authority, there can be few which better represent its strong rhetorical appeal and its consistent application than that which occurs at White House Correspondents' Dinners.

Hosted annually by the White House Correspondents' Association (WHCA), the dinners have come to be widely recognized as events in which some of the most powerful individuals in the world gather to make light of current events, the political system, the media, each other, and, of particular interest to this thesis, oftentimes themselves as well (Culberson, 2013; "History of the," 2013). I will suggest that the dinners serve as something of a rhetorical stage, the rhetors acting both to espouse political doctrine while 
also entertaining allies and detractors alike in a show resembling humorous pageantry. In essence, the speakers at White House Correspondents' Dinners serve as both king and jester, using the resulting incongruence to amplify the effect of the self-deprecating humor used and, by consequence, their persuasion attempts. Thus, a dinner functions as an excellent text to analyze the rhetorical successes and failures of the use of selfdisparaging humor.

To be clear, though much of this thesis will consider self-disparaging humor as it is used by political figures, I will argue that its use by individuals recognized as authority figures from any background can be appropriate and successful. I define authority figures as individuals whom an audience recognizes as possessing a deal of credibility, using Aristotle's (2010) explication of ethos, in the field in which they work and are perceived as being, at least on some level, socially "above" themselves. Thus, a list of authority figures would include (but would not be limited to): teachers, politicians, doctors, religious leaders, and so on.

This analysis will shine light on what has thus far been a murky field of study. It is my hope that this thesis will serve to inspire further analysis on self-deprecating humor, particularly as it is applied in rhetorical contexts. 


\section{CHAPTER II}

\section{REVIEW OF RELATED LITERATURE}

Author E. B. White (1941) once remarked, "Humor can be dissected, as a frog can, but the thing dies in the process and the innards are discouraging to any but the pure scientific mind" (p. xvii). White's charge is not without merit; to explain a joke is, after all, often thought of as a sign that the joke was not especially humorous in the first place. Yet this belief is predicated on the idea that the use of humor is generally a base, thoughtless process which necessarily lacks higher consideration. I submit, however, that the use of self-deprecating humor, at least in certain contexts, is a calculated rhetorical strategy to curry favor with others and to increase one's standing to an audience which merits further analysis.

To expound on this premise, it is necessary to understand first the basic tenets of rhetoric which coalesce to make up the precise persuasive situation in which selfdeprecating humor is most efficacious and useful. The concept of social stratification is likewise an element of scholarship which must be considered, for it is the mitigation of its negative effects on perceived character and goodwill that self-deprecation is employed. Of course, self-deprecating humor cannot be properly understood without understanding why it is humorous and successful for its audience as a means of spreading goodwill and serving as a useful rhetorical strategy by authority figures. Political humor, then, serves 
as a specific subset of humor which carries with it its own unique facets, the appreciation of which is necessary to grasp the proverbial arena which is the White House Correspondents' Dinner. Finally, self-deprecating humor itself, rhetorically controversial tool as it is, must be briefly appraised in terms of existing scholarship.

\section{The Art of Rhetoric}

By its nature of being a risky rhetorical tactic to employ, the use of selfdeprecating humor to persuade demands perhaps a more keen understanding of the rhetoric as an art and the rhetorical context in which it is employed than might otherwise be needed for more common persuasive means. The success of self-deprecating humor is predicated on a multitude of rhetorical facets, an explanation of which follows.

\section{Ethos and Image}

According to Aristotle (2010), there exist three qualities an audience considers when assessing an orator's message, which he attested, aside from evidence itself, can be used to persuade: perceived goodwill, good sense, and good moral character (p. 60). Aristotle's axiom on character is one which, though perhaps obvious, is nonetheless crucial when determining the success of a rhetorical appeal: individuals are more inclined to believe a rhetor that they perceive to be credible. Put simply, as Aristotle attested, "We believe good men more fully and more readily than others" (p. 8). The success of a persuasion attempt, then, can live or die on an audience's perception of the persuasion agent's character, or ethos.

An important consideration of Aristotle's view of ethos was his suggestion that credibility should generally be established through what the speaker says and not what is previously thought of their character (Shields, 2012). Sillars and Gronbeck (2001) 
expound on the idea further by suggesting that an individual's reputation serves as "nonartistic proof" and that to evaluate a rhetor's message by their reputation alone is to ignore the actual message itself (p. 129). Clearly, this line of thinking attests to the primacy of message content and delivery for ascertaining ethos over preconceived notions of character judged from less "artful" facets.

To follow that view too strictly, however, would be to ignore a multitude of other facets a rhetor possesses which can influence audience perception. In spite of Aristotle's emphasis on the importance of a rhetor's message over their reputation, rhetorical scholars do not ignore the significance of the non-message facets which influence reputation. Amossy (2001) attempts to reconcile the sociologist stance on ethos which states that it is predicated on the rhetor's "institutional position," with that of individuals like Aristotle and French linguist Oswald Ducrot who believe it is based on discourse alone (p. 1). The sociologist perspective, Amossy submits, is that no speech can be divorced from the position of the rhetor from whom it is given (p. 3). In other words, a message cannot stand alone, for an audience will also necessarily consider the rhetor's background and the non-verbal signals given. The pragmatist perspective on the other hand assesses the message itself to judge ethos (p. 4). Amossy describes the conflicting beliefs thusly:

The pragmatists' ethos, descended from Aristotle, is constructed within verbal interaction and is purely internal to discourse; the sociologists' ethos, on the other hand, is inscribed in a symbolic exchange governed by social mechanisms and external institutional positions. In a perspective opened up by rhetoric, however, these two approaches can be complementary rather than conflictual (p. 5). 
To resolve the differing concepts of ethos, Amossy draws from the concept of prior ethos or "prediscursive ethos" which is defined by the reputation a rhetor has before a message is given (p. 7). How prior ethos may be conferred is predicated on the individual and the individual's status. Those who are famous and thus covered in the media necessarily have a very many outlets through which their reputation is formed. A president, for example, will have had a great deal of media coverage and will consequently be very familiar to the masses. Those who are not famous, however, may have their reputation flavored by attributes, stereotypes, or "ready-made predicates" (pp. 7-8). These qualities can include but are not limited to: nationality, job, political affiliation, or gender. Amossy suggests that this kind of generalization is of great value for a rhetor, for it allows an audience to affiliate with the orator categories, giving the audience a frame of reference and thus allowing them to better associate with the speaker (p. 7). Of the value of such prior ethos, Amossy concludes: "Taking into account the prior ethos of the speaker as a representation anchored in familiar stereotypes allows for a better understanding of the strategies deployed in the discourse to consolidate or improve the orator's image of self' (pp. 8-9). A reciprocal relationship is thus created between discursive and prediscursive ethos; how we are perceived affects how others perceive the messages we send, and the messages we send in turn shape our reputation.

Sillars and Gronbeck (2001) expound on this concept by drawing forth the notion of the rhetor's image. Distinguished from ethos, image specifically refers to the kind of visual picture which a rhetor projects on an audience (p. 129). In essence, the rhetor's image is that which appears in our mind when we think about the rhetor. Thus, it is in the 
rhetor's best interest to project an image which is favorable in the minds of those whom they wish to persuade and which is congruent with the nature of the message they send. To do this, a rhetor must necessarily be cognizant of the audience which they address and what they wish to persuade the audience to believe or do (Amossy, 2001, p. 7). A teacher, for example, must construct an image which projects a mastery of knowledge; a presidential candidate must portray an image which suggests benevolence, authority, and confidence; and a psychologist must be perceived as professional while still maintaining a sense of warmth and sympathy for their patient if they wish to be well-received. Later, I will make the argument that authority figures use self-deprecating humor as a calculated means, in part, of shaping, enhancing, or restoring their image, both proactively and in response to criticism from others.

The success of using self-deprecation as a means to enhance a persuasion attempt is heavily contingent on the perceived character of the rhetor that uses the risky brand of wit. Indeed, the perception of self-disparagement observed holistically changes based on the audience's perception of by whom it is used. A nebbish, insecure individual who is self-deprecating can diminish their character as the humor is perceived to be the result of self-doubt and low self-worth, since the use could be perceived as a self-pitying appeal for affirmation. Yet rhetors who are already perceived to be credible, confident, and who are thought to express goodwill for their audience, on the other hand, can successfully use self-deprecating humor because it is understood that its use is not made out of desperation and that such humorists are not truly as down on themselves as they imply through their self-disparagement. 


\section{Authority}

Titles, positions, expertness, and experience are all capable of conferring perceptions of credibility without each individual to whom the designation belongs needing to actively prove credibility themselves. Based on the hitherto established concept of prior ethos, authority describes a credibility-enshrining facet which is established before a rhetor speaks (Whitehead, 1968, p. 59). In a sense, the qualities which denote authority can be seen as something resembling rhetorical "testimonials" for indicating credibility. Like a good reputation that precedes an individual, a perception of authority grants respect and confers approbation.

Hartelius' (2011) The Rhetoric of Expertise provides an in-depth look into the concept of expertness and the rhetorical framework which exists between authority figures and those who abide by authority. The author suggests that the reverence we give to those we perceive to be authority figures is born largely out of a fear of ambiguity ( $p$. 1). In essence, we defer to expertness and authority because we recognize something in ourselves that we lack — knowledge, ability, or experience, for example-yet which others possess and through whom we may assuage such uncertainty. Nevertheless, the book makes the argument that merely being proficient in something does not in and of itself bolster all persuasion attempts. Rather, it is made clear that it is when combined with a good deal of rhetorical acumen that the rhetor can use their position of authority to convince others; in the author's words:

Experts use both their 'real' knowledge and experience in a specific field and their rhetorical prowess to persuade an audience. ...effective rhetors rely on 
multiple means; the more they have at their disposal, the more likely they are to be viewed as experts (p. 9, emphasis in original).

Hartelius breaks down expertise into four main contexts: political, historical, medical, and informational (pp. 15-17). The author posits that these four contexts are those which make up most public discourse on the subject of authority (p. 18) and that, irrespective of which of the four areas of expertise is assessed, common arguments and rhetorical appeals recur (p. 29).

The crux of Hartelius' argument is that the persuasive authority figure is not passive in their assertion of credibility. Rather than merely relying on those laurels which might suggest credibility based on their position, a truly successful authoritative rhetor must be mindful of many other facets in order to best persuade. Hartelius sums up the process thusly:

[experts] engage the public, adapt strategically to the constraints of audience and context, and discern the available means of persuasion. They compete for our trust and consent. They argue for the validity and relevance of what they provide. The notion of a rhetoric of expertise connotes systematicity - a pattern, a form, a genre. It suggests that experts from a range of specialties face the same discursive challenges and employ the same tactics. Beyond the other elements that comprise expertise — knowledge, experience, skills, etc. - rhetoric is integral to the phenomenon's cultural prominence (p. 171).। 


\section{Goodwill}

Beyond establishing good character and an expertness in the field in which they aim to persuade, a successful rhetor must be perceived as expressing goodwill as well. According to Fortenbaugh (1992), Aristotle would have recognized a rhetor who expresses goodwill as being "[a] just man who prefers to sacrifice his own interests rather than to profit from the state" (p. 215). Such an orator, then, is one who is perceived to be magnanimous, a particularly important trait to possess in a situation when the orator is an authority figure given the social distancing which occurs between themselves and their audience.

In the context of an authoritative rhetor attempting to persuade an audience, it can be said that goodwill is also synonymous with approachability. An authority figure will necessarily possess perceived credibility, but they must also be recognized as someone who has the audience's best interests at heart. A rhetor who uses self-deprecating humor sacrifices something about themselves — seriousness and perhaps some of their credibility which they can "afford to spare"- which expresses humility and modesty for the benefit of the audience, and, as a consequence, for the benefit of the rhetor as well.

Weresh (2012) considers goodwill as it is lost and gained in the context of the rhetorical situation between authority figure and audience. Condescending prose ("Look, it's like this"), bluntness, and overt displays of superiority alienate and distance the rhetor from the audience, as the rhetor loses a sense of likeability and trustworthiness (p. 231). Tactics such as the use of humor, however, help to spread goodwill by painting the rhetor in a better, more relaxed light (p. 260). Of particular interest to this thesis, selfdeprecating humor specifically is identified as a means of expressing goodwill: 
Self-deprecating humor — if employed appropriately—is most likely to reinforce the character of the advocate...Almost everyone responds favorably to those who take themselves down a peg or two, mainly because everyone likes to feel that a person, however exalted, is human after all and does not exaggerate his or her own achievements (pp. 261-262).

Self-deprecating humor can act as a means of leveling, lessening the distance between speaker and audience by removing the perceived differences in status that exists between them. To wit: a boss will necessarily have a higher income than his or her subordinates, yet he or she can nonetheless poke fun at his or her outfit by remarking that it was purchased at a thrift shop, for example. Goodwill, then, is about establishing a relationship or bond between rhetor and audience.

The concept of goodwill is as multifaceted as the kind of rhetorical appeals a rhetor can make. Precisely the sort of goodwill which is offered and desired by an audience is predicated on the rhetor, the context of the persuasion attempt, the audience themselves, and the relationship between rhetor and audience. A professor, for example, can coney goodwill by expressing confidence in students' abilities and encouraging them to succeed, while a boss can likewise ingratiate him or herself by leading workers with humility and benevolence. In sum, all the expertness and character in the world amounts to little if an audience does not feel as though the rhetor to whom those qualities belong has their best interests at heart. 


\section{Identification}

According the Burke (1969), a crucial component of successful persuasion is one party identifying with the other. Burke recognizes that schisms which inherently exist between individuals and the subsequent need to bridge those schisms by identifying commonalities that exist to facilitate communication. Rhetoric, Burke (1969) attests, "considers the way in which individuals are at odds with one another, or become identified with groups more or less at odds with one another" (p. 22). Identification, then, is "compensatory" (p. 22) to differences which occur-in other words, it mends the bridges between individuals which may otherwise exist.

For a speaker in a position of authority, such schisms between the speaker and his or her audience may be perhaps greater than between individuals on more equal social standing. A president, for example, would thus benefit tremendously from appealing to his or her audience through the acknowledgement of commonalities which exist between the two parties. With self-deprecating humor, an authoritative rhetor may recognize the existence of a disparity between his or her social level and that of his or her audience, and work to suggest that such disparities are not as large as perceived through its power to humble and express humility. Through the use of self-deprecating humor, a president thus may suggest that he or she is "one of us."

\section{Rhetorical Situation}

The rhetor's decision to use humor-self-deprecating or otherwise — suggests that a situation exists which they believe calls for the persuasive tactic to be appropriated. Much as the author who writes a historical account of a war must necessarily understand the social, political, and historical background that precipitated the war, so too must a 
rhetor be aware of the many factors which shadow the context in which the persuasion attempt is to take place. Lloyd Bitzer's (1992) aptly titled essay “The Rhetorical Situation" sets forth the notion that situations trigger rhetoric and that these situations merit analysis every bit as much as other, commonly assessed facets of rhetorical discourse (p. 218). The "situation" in Bitzer's concept of a rhetorical situation is not about the context in which the persuasion attempt is made, but rather the situation which necessitates the rhetoric which occurs in the first place (pp. 218-219). Rhetoric, Bitzer argues, is pragmatic, an art which is honed and applied to incite action or to enact change in the world. The rhetorical situation then includes the characteristics of the situation which bolsters the desire to spur action or change; exigence, which is an urgent need or demand, the audience, which are the individuals who stand to be influenced by the discourse and can enact change, and constraints, which Bitzer describes as being the facets of a situation which have the ability to constrain action and decision, and includes the likes of beliefs, traditions, motives, facts, and so on (pp. 221-222).

An understanding of the rhetorical situation in which the decision to employ selfdeprecating humor occurs helps to answer the "why" questions: why that particular brand of humor is employed, why the humor succeeds as a rhetorical strategy, and why the humor is meritorious of analysis. I submit that self-deprecating humor can be thought of as like any other kind of persuasive method in that its appropriation is predicated on specific circumstances occurring which make its use helpful to the rhetor.

\section{Epideictic Rhetoric}

Distinct from the rhetorical situation, which is the context in which the use of rhetoric is necessitated, the nature of the kind of rhetoric employed must itself also be 
taken into consideration. Aristotle (2010) sets forth the notion that rhetoric can be divided into three distinct categories: political, forensic, and epideictic, or ceremonial rhetoric (p. 15). Epideictic rhetoric, Aristotle attests, is rhetoric which is used to praise or blame and can be found in situations like funerals, anniversaries, inaugurations, and other formal events (p. 16). Thus, epideictic oration focuses on the present. Aristotle suggests further that three categories of rhetoric, broken down to their core purpose, each has their own specific outcome, with epideictic rhetoric serving to praise or attack and, in doing so, bolster or denounce respectively (p. 16).

Expanding on this idea, Zeytinoglu (2008) defines epideictic rhetoric as facilitating the "social amplification of ideas and people through a heightening effect" ( $p$. 18). Distinct from the other two forms of oration, epideictic rhetoric is considered to be the most "literary" as it is meant to be read (Aristotle, 2010, p. 184). Burke (1969) agrees, suggesting that epideictic rhetoric is that which is often poetic, playful, and esthetic (p. 72). Here, we may draw a connection with epideictic oration and humor which, by its very nature, is decidedly playful.

It is in a ceremonial context, Aristotle (2010) suggests, that persuasion attempts are not contingent on proof, but simply are taken at face value: "The facts themselves are to be taken on trust; proof of them is only submitted on those rare occasions when they are not easily credible or when they have been set down to someone else" (p. 197). To this end, an epideictic speech is such where an audience is not as critical as would be expected in another kind of persuasion attempt; a rhetor's authority, coupled with the specific context in which the rhetoric is taking place, creates a situation in which an audience is more likely to give a rhetor the benefit of the doubt on that which is being 
expressed.

I submit that the annual White House Correspondents' Dinner and the speeches given therein fall under the auspices of epideictic rhetoric. The ceremonial nature of the dinner, the relationship the audience has with the speakers (generally the President of the United States and other high-ranking political officials or well-regarded media figures), and the expectation of the kinds of speeches that will be given makes it understood that the speeches are distinct from other, more overtly political ones.

Moreover, the use of self-deprecating humor common in speeches given at the dinners is consistent with tenets of epideictic rhetoric; the humor is used to both attack oneself yet, given the nature of the attack, also praise oneself, and further, such humor is necessarily playful. Divorced from many of the typical characteristics of formal political oratory, an audience's expectation of each WHCD is that speeches given will be light and jocular, and free from the more overt political demagogy which might otherwise be expected from a president at the podium. As a consequence, an audience at such a dinner would be less likely to listen to the speech with a critical mindset.

\section{Social Stratification}

The nature of the existence of authority and those so defined as authority figures requires that there must necessarily be a hierarchal structure which places some individuals above others. In this context, "authority" need not have the same connotations of subjugation or oppression that the word may evoke in some. The term can merely be synonymous with expertness, experience, or rank (Hartelius, 2011, pp. 2-3). Moreover, those who are "below" the authority figures should not be thought of as being inherently marginalized or discriminated against. 
Indeed, Dahrendorf (1959) distinguishes authority from abject domination by referring to it as being a "legitimate relation" to individuals that "exists as an expectation independent of the specific person occupying the position of officer, manager, civil servant" (p. 95). By this definition, authority is not an arbitrary construct invoked to suppress, but rather is merely an identity which is maintained and respected in accordance with societally held beliefs of expertness, experience, knowledge, or accreditation. This, then, is the definition of authority that I shall adhere to hereafter.

Nonetheless, in spite of the relative "fairness" of such authority, the nature of authority does suggest that differences between the "self" and "other" exist, which can nevertheless serve to distance the two parties (Riggins, 1997, p. 4). Such differences, if they are perceived as being significant enough, can stratify and, as a consequence, create barriers which impede successful discourse between speaker and audience. Moreover, authority suggests power, which in turn implies further that those who give deference to authority lack such power (Saha, 2006, p. 59). Those who feel they lack power can harbor a litany of negative feelings about those who it is believed do possess it; feelings of resentment, inferiority, a lack of agency, respect, or relatability, and so on can be pervasive (Magee \& Smith, 2013, p. 163). These feelings and others can resonate in audience members who defer to authority, lessening the persuasive impact of the message given on account of a perceived lack of goodwill.

Consequently, it is in an authoritative rhetor's best interest to assuage such feelings which distance speaker and audience. Once more, we must consider the concept of goodwill and how an audience perceives the rhetor in terms of whose interest they have at heart. Students to teachers, patients to doctors, employees to bosses, constituents, 
media, and subordinates to politicians, and so on, irrespective of the specific relationships, the relationship between those in a position of authority and the individuals who recognize them and acquiesce to that status is one which must thus be taken into consideration when considering rhetorical discourse which occurs between the segmented groups.

\section{Social Stratification in Organizations}

There can be few better situations to observe power dynamics in play and social disparities mediated than in organizational culture. An organization, generally, implies a hierarchy, which in turn implies stratification (De Crespigny \& Wertheimer, 2010, p. 145). Hofstede's (1989) concept of power distance was devised to explain the degree of acceptance of such stratification and the disparities of power in a societal context. The United States, for example, has a society in which egalitarianism is stressed; consequently, the U.S. generally has a lower power distance. In nations like China, however, there exists an emphasis on an unquestioning obedience to authority, and thus is there the existence of a higher power distance (Zhang \& Begley, 2011, p. 3602). In essence, irrespective of society, Hofstede recognizes inequality in an organizational context as being both "inevitable and functional" (p. 65). Inequality in an organization, Hofstede argues, is necessary in some respects in order to prevent disorder (p. 69).

Nevertheless, Hofstede submits that in a nation in which stratification tends to be more significant, subordinates tend to fear the authority figure and neglect to question them (pp. 73-74). In an organizational context, the potential negative consequences of this are obvious; workers recognize themselves as lacking autonomy, empowerment, a desire to incite change, and an opportunity to innovate (Zhang \& Begley, 2011, p. 3605). 
Indeed, in Zhang and Begley's (2011) study assessing power distances between American and Chinese workers and their subsequent perceptions of empowerment, it was found that there was a positive correlation between feelings of empowerment and team participation (pp. 3610-3611).

If we are to "unpack" this idea and divorce the concept of power distance from a purely organizational context, I believe this explanation of the stratification which exists between those in authority and those who follow them has benefit in the domain of rhetorical discourse. While a boss' desire to lower the perceived social distance between him or herself and their audience is predicated on a different general outcome than a rhetorician's - that is, increased productivity and group participation over persuasion of another form - the context in which their rhetoric is used to mediate power distance and the overall goal is nevertheless the same: the creation of a more egalitarian relationship to increase goodwill and thus, to make the audience more amenable to attitude change or to carry out a desired action.

\section{Humor as a Unifier}

Francis' (1994) study on humor as emotion management expands on the premise of humor as a means of lessening social distance by arguing that humor can be appropriated to generate positive sentiments between parties which creates bonds and, in turn, mitigates external threats (p. 147). Francis uses the example of humor as it is employed by hospital workers for the benefit of patients; she points out that although medical authority is highly respect in America and is thus often unquestioned, there nonetheless exists a litany of instances where a patient may harbor feelings of uncertainty and unease. In this context, Francis suggests, humor can serve to not only assuage such 
feelings of unease in the patient, but also to ensure smooth operations for the patient's treatment by bolstering their trust of the medical professionals (p. 153). Persuasion, Francis asserts, has an emotional component, and through the use of humor as emotion management, a rhetor can work to create a bond and mitigate any unease or perceived distances between authoritative rhetor and their audience (p. 161).

\section{Humor}

The existing scholarship on the subject of humor is abundant. Its prevalence among peoples of all creeds and backgrounds, its association with joy and camaraderie, and its truly multifaceted and multi-purpose nature all explain in part why research into humor spans a litany of disciplines. Psychology, philosophy, communication, physiology, and rhetoric, all are subjects which seek to explain certain facets of humor and which, when combined, provide a better understanding of how and why we laugh.

\section{Humor as Persuasion}

Humor, unifying force as it is, can create commonalities among individuals where commonalities might not otherwise exist. The successful use of humor suggests a common ground between the humorist and their audience implying that both parties are on the "same page" and thus making the audience more amenable to persuasion (Meyer, 2012, p. 23). To that end, humor as a method of persuasion is heavily contingent on ethos-building and the spread of goodwill. If an audience perceives a rhetor to be of good character and to be well-meaning, the persuasion attempt will necessarily be better received than if the rhetor is perceived to be arrogant and have only his or her best interests at heart. Gruner's (1967) study on the use of humor as a character-building tool affirms this belief (p. 223). 
Aristotle recognized the value of humor as a rhetorical tool, though he was also of the belief that certain kinds of humor were not appropriate for civil discourse. Aristotle suggested that a rhetor should be ever-cognizant of the situation in which the persuasion attempt is to take place and to whom it is aimed when considering whether or not humor is appropriate: "The gentleman would know when not to make a hurtful sally and when levity would be appropriate" (Billig, 2005, p. 45). Thus, as with any other rhetorical strategy, a rhetor must be ever mindful of the situation in which the persuasion attempt is to take place.

\section{Theories of Humor}

Of all the research that exists on the subject, I posit that there are three core principal theories of humor which are of particular importance in understanding how selfdeprecating humor works, why it works, and how it affects us psychologically and physiologically. Divorced from the rhetorical context in which it can be used, an understanding of the appropriateness and the efficacy of the use of self-deprecating humor is contingent on an understanding of these theories.

Incongruence Theory. The element of surprise, often, is the humorist's best friend. This is true irrespective of the specific genre of humor considered; satire, slapstick, deprecating humor, and so on, all can make use of surprise to make us laugh. From an infant's laughter elicited from the shock of a parent hiding behind a blanket and shouting "boo!" to humor drawn from the sight of an elderly man breakdancing, exposure to something which we do not expect can incite humor. In this sense, humor is like a rollercoaster, insomuch as the joy we derive is predicated on a kind of shock. This humor, then, is born out of an incongruence, which can be defined as "the divergence between an 
expected and an actual state of affairs" (Deckers \& Kizer, 1975, p. 215). Explicating on the phenomenon further, 18th century writer Beattie describes the theory thusly: "Laughter arises from the view of two or more inconsistent, unsuitable, or incongruous parts or circumstances, considered as united in one complex object or assemblage" (quoted in Martin, 2007, p. 63).

Yet the implications of this theory are more far-reaching than merely equating general surprise with a humorous outcome. By its very nature, to be surprised is to have had an expectation of some sort violated. Morreall (1983) suggests that we derive humor from the surprise which results from witnessing an act which violates such an expectation - an observation of incongruence, in other words - which is the result of an instance of disorder in an otherwise ordered, patterned world (pp. 15-16). This explanation positions humor as being a kind of release in response to a regimental society. Humor, then, allows us to find joy in that which is contrary to the preconceived notions we have about the world.

Holland (1982) suggests that ethical incongruities can also be humorous. Such a violation, Holland attests, is one which results from two dichotomous characteristics interacting; in other words, incongruity which is "between the noble and the contemptible, the high and the low, the sacred and the profane, the splendid and the scorned —finally, good and evil”' (p. 22). Consider, for example, Mel Brooks' (1967) comedy The Producers and the infamous "Springtime for Hitler" scene. In the play within the play, the bombastic, flamboyant, over-the-top musical performance celebrating Adolph Hitler's ascension to power is humorous strictly because we, the audience, are aware of the true brutal nature of the dictator and his regime; the garish, ostentatious 
spectacle, then, is highly ill-fitting of how we expect a portrayal of the Nazi leader to be. In accordance with the principles explicated in the theory of incongruence, such humor is born because we recognize what is ethical, and we understand how such a scene is in gross violation of such tenets. The concept of ethical incongruities best illustrates, I think, the idea of universally held beliefs and how their violation, too, can be humorous. In the context of the use of self-deprecation by an authority figure, if we recognize that such a figure acts differently than we think they "should," we derive humor. The success of such humor is thus predicated on the audience to whom the humor is directed understanding precisely how the humor is incongruous.

When it is successful, self-deprecation "works" for authority figures because we are aware that their self-disparaging jokes are just that—jokes. When used by authority figures, it is evident that self-deprecating comments are contradictory in nature because they violate an understanding we have of their character set forth by whatever characteristic makes us aware of their position of authority. A tenured professor who teaches a computer programming course may remark that he doesn't know how to send an email, for example, yet his position as a tenured professor in such a field makes it abundantly clear that the comment is not to be taken literally. Thus, self-deprecation is successfully humorous because of the resulting incongruence between an expectation and an action, and yet self-deprecating humor does not harm credibility when used in this context because we are aware that the comments are told in jest.

Superiority Theory. The superiority theory of humor suggests that humor can be evoked through the disparagement or belittlement of others (Ferguson \& Ford, 2008, p. 283). Simply stated, this theory sets forth the notion that we derive humor when we are 
able to compare ourselves to those who are worse off than we are and subsequently feel better about ourselves in comparison. This kind of humor should be obvious to anyone who has snickered when witnessing a person tripping over their shoelaces or a when watching a celebrity roast, for example. English philosopher Thomas Hobbes' definition of laughter, in fact, is partly predicated on the tenets of superiority theory and is described thusly: "Sudden glory is the passion which makethed those grimaces called laughter; and is caused either by some sudden act of their own, that pleaseth them; or by the apprehension of some deformed thing in another, by comparison whereof they suddenly applaud themselves" (Ewin, 2001, p. 29).

The disposition theory of humor edifies the superiority theory in that it provides an explanation of precisely how much humor we derive from the disparagement of others. Zillmann (1983) suggests that the humor we gain is proportional to how negatively we feel about the party from whose misfortune we draw delight (pp. 90-92). The victimization of those we resent, for example, is more likely to be humorous to us than would be the victimization of those for whom we have positive feelings (p. 92). As such, given we tend to be less close with authority figures, it can be said that the disposition theory helps to explain why we find self-deprecating humor at the expense of a person of authority amusing. Moreover, as a rhetorical strategy when used by politicians, self-deprecating humor may in fact function particularly well in currying favor of detractors, for by their nature as opponents, they already think poorly of the individual making the joke.

Charles Gruner's (1997) book The Game of Humor posits that humor can be thought of as a game through which a winner and a loser is determined. In the context of 
persuasion, the party that "wins," Gruner attests, is the one which manages to convince, convert, or persuade the other (p. 8). Broken down to its most basic thesis statement, Gruner suggests that "laughing equals winning" (p. 8). To that end, Gruner's book is heavily predicated on the superiority theory of humor insomuch that the winner- the one who laughs — is able to feel a sense of superiority over the one from whom laughter is elicited.

Adhering to Gruner's premise can prove to be greatly helpful in explaining the success of the use of self-deprecating humor by individuals in positions of authority. In the unique rhetorical situation created when individuals who are in such a position must address those who are not, I submit that they can actually "win" by "losing." Authority figures, their credibility self-evident by virtue of their position, can thus afford to "lose" to their audience in the "power-play" which ensues when the humor is used. By allowing individuals to gain a victory at their own expense, authoritative rhetors also grant said individuals a feeling of superiority relative to the rhetor and thus, lessen any perceived social disparity based on feelings of inequity such individuals may feel (Rancer \& Graham, 2012, p. 14). By endearing themselves to others through the expression of humility, rhetors that are authority figures can still persuade in spite of their "losing."

In this, the use of self-deprecating humor as a rhetorical strategy is equivalent to taking a dive in a game. Just as one who willingly loses at something generally does so because he or she stands to gain something thought to be better than that which would be obtained by winning (a significant profit from a bet made against oneself, for example), so too is self-deprecating humor leveraged to gain a rhetorical benefit which is more desirable than anything about a rhetor's character that stands to be lost in its use. In that 28 
sense, the use of self-deprecating humor amounts to a rhetorical wager, and is thus highly strategic, appropriate only at certain times and for certain audiences.

Relief Theory. Though explaining the nature of what we laugh at and the emotional responses which we might display through humor, the aforementioned theories of humor fail to provide an explanation for our physical response to humor. Morreall (1983) posits that relief theory explains humor's biological function and why laughter takes the physical form that it does (p. 20). Spencer (1911) suggests that laughter is the expulsion of a build-up of tension. In essence, the relief theory states that laughter is the result of the body's attempt to relieve itself from anxieties which result from suppressed feelings. Laughter, then, is the physical expression of "muscular excitement" (p. 164) and can be recognized as the "gush of agreeable feeling that follows the cessation of mental strain” (p. 165). In essence, laughter is something like bodily liberation.

Morreall (1983) speculates further and suggests that such tensions could be the result of societal prohibitions on that which is socially acceptable to find humorous (p. 21). Essentially, traditional mores and social conventions often dictate that which we are "allowed" to find humorous. Consider, for example, the delight a child has when using a swear word which his or her parents have expressly forbidden him or her to use. In this, relief theory follows the previously mentioned incongruency theory of humor in the sense that we find humor in that which violates an expectation and we laugh because the violation provides a release of nerves built up by a strict adherence to following those expectations. On this, Morreall explicates: "If a schoolboy hates his teacher, for example, he is not allowed to take out his hatred by assaulting the teacher...if the teacher should suffer violence at someone else's hand, however-say the student hears that the teacher 
was mugged — or if the teacher should simply trip and fall in front of the class, the pentup energy of the student's hatred will find release in his laughter" (pp. 21-22).

\section{Humor and Power}

As illustrated, humor can be used to relieve social tensions and provide goodwill by lessening perceived differences in an authority figure and the figure's audience. In the context of authority and balances of power, humor provides "Important social functions for both resistance and control" (Smith, 1993, p. 51). In that sense, humor is like a tool in that the outcome of its use is determined by the will of the individuals by whom it is used.

Bakhtin's (1984) concept of the carnivalesque explicated in his work Rabelais and His World is broadly used to describe the use of humor to subvert social norms. Carnival, the season of festivals which occurs before Lent, was a time in which individuals could act in ways which would violate otherwise strictly sacrosanct, immutable social tenets through elaborate, oftentimes hedonistic celebrations. Put simply, the existence of the Carnival spoke of a dichotomous society which consisted of the serious, "official" solemn, humble world of law and order represented by Lent, and the burgeoning subversive, energetic underbelly which lay repressed until such sanctioned time that individuals were permitted to act out, as they could during Carnival. The crux of Bakhtin's argument is that, during Carnival, individuals of all backgrounds could essentially act as each other and ignore regimentation, in spite of the fact that in such stratified societies such an act would normally be impossible under any other circumstances. On this, Bakhtin notes that Carnival is not "a spectacle seen by the people; they live in it, and everyone participates because its very idea embraces all the people. 
While carnival lasts, there is no other life outside it. During carnival time life is subject only to its laws, that is, the laws of its own freedom. It has a universal spirit; it is a special condition of the entire world, of the world's revival and renewal, in which all take part" (pp. 7-8).

Billig (2005) dedicates a chapter to his book Laughter and Ridicule: Towards a Social Critique of Humor to how humor is used to affirm and contradict social order. Referencing Bakhtin, Billing suggests that humor is positive if it is disparaging of social order, but if the humor bolsters and affirms the order, it is negative (p. 201). To this end, humor can liberate in its creation of an egalitarian situation. Through the use of humorous discourse, it is understood that the social world as we know it no longer has its tendrils around us to force us to act in accordance with such rigid structures (p. 208).

Humor, in many ways, can be freeing. As Morreall (1983) attests, "The person with a sense of humor can never be fully dominated, even by a government which imprisons him, for his ability to laugh at what is incongruous in the political situation will put him above it to some extent, and will preserve a measure of his freedom-if not of movement, at least of thought" (p. 101). It is predicated on this liberating nature of humor which makes that of the self-deprecating kind useful for authority figures. To see those "above" us taken down a peg makes us feel better about ourselves. To that end, the power-diminishing facet of humor is predicated on all three of the aforementioned theories of humor: to subvert established social norms of how authority figures should acts calls forth the concept of incongruity, to see those in authority disparaged makes us feel better about ourselves which thus lessens the perceived distance between them and us, and the humor we derive from such disparagement grants us a release from physical 
and social tensions which cause us anxiety.

\section{Political Humor}

“The political sport of comic insult," Schutz (1977) asserts, "is like sports in general, a kind of mock warfare" (p. 48). Such sport, Schutz suggests, seeks to provide both a diffusion of political tensions as well as an outlet to express our aggressions in a way that is socially acceptable (p. 48). Referring to politicians' use of humor as both a sport and mock warfare is an altogether appropriate one; politics, like sports and warfare, is generally a competition between sides, and likewise results in winners and losers. Moreover, just as both games and war can be won through an adherence to strategies which are appropriate for the situations in which they are applied, political humor is an art which can be applied to a great many situations to derive an equally large number of desired outcomes.

\section{Political Humor and Persuasion}

Political humor, according to Becker (2012), is generally broken down into two types: humor at the expense of others, and self-ridicule humor (p. 791). The use of either type of humor is predicated on what the humorist wishes to persuade his or her audience to feel or believe. To use disparaging humor at the expense of a competitor is to attempt to diminish them and to bolster the individual doing the disparaging by proxy. Such humor is, by its nature, hostile and thus is generally perceived to be more negative (Becker, 2012, p. 806). Self-ridicule, however, is considered positive and reflects goodwill (Becker, 2012, p. 797).

The competitive nature of politics plays a role in the effect of humor used. In a study on audience perception of political humor, Bippus (2007) found that individuals 
tended to perceive politicians' humor which was directed at themselves, which is seen as mediating, more favorably compared to humor made at the expense of others, which is perceived as being more aggressive (p.116). Moreover, it was found that individuals had no real preference about the political party of the politician using humor respective to their own political allegiance, as it was shown that there was no correlation between audience political affiliation and perceived effectiveness of the humor used (pp. 116117).

The results of the above studies both show positive perceptions of selfdeprecating humor. Political humor can be caustic and inflammatory, or it can be used to seek harmony and accord. When used to bolster ethos it seems apparent that humor that is aimed at oneself is that which is more successful. Such a strategy can persuade by suggesting goodwill through positioning the rhetor that uses it as being "above" the petty mudslinging used by other politicians by expressing humbleness. In general, the use of humor takes a bit of gravity away from the political process and makes it more approachable to those who would otherwise find its seriousness and perceived dower nature off putting.

\section{White House Correspondents' Dinner}

The annual White House Correspondents' Dinner (WHCD) is held by the White House Correspondents' Association and has served to bring together journalists who cover the White House with politicians and dignitaries since 1920 ("History of the," 2013). It was not until 1983 when the headliner of the dinner was comedian Mark Russell that the annual event began to resemble the roast-like spectacle it is today, however (Edwards, 2011). Since then, the dinners have come to be recognized as events in which 
the President of the United States and others use the podium to not just spread political dogma, but to act as comedians as well.

I submit that the WHCD functions much as the aforementioned concept of carnival discussed by Bakhtin (1984). Politics, a subject which by its nature is generally very reserved and serious (Schutz, 1977, pp. 23-24), loses much of its solemnity at the WHCD and thus are many social conventions temporarily suspended. The incongruence which results from politicians acting in a way that is not accordant with generally held beliefs about how they should act strengthens the rhetorical appeal of self-deprecating humor, both as a strategy to enhance their character, as well as to persuade those in the audience. This is so because self-deprecating humor increases levity and humbles the rhetor, making even an authority figure as unique as president of the United States seem less lofty.

\section{Self-Deprecating Humor}

Self-deprecating humor is defined as a "discursive activity increasing one's own standing by doing (apparently) the contrary" (Priego-Valverde, p. 4). Thus, such humor is based on saying one thing while meaning something entirely different. To this end, the success of self-deprecating humor is contingent on the audience understanding that the humor attempt is just that. If the audience perceives the self-deprecating comment at face-value, the rhetor stands to lose credibility he or she wished to gain. In this sense, self-deprecating humor, when successful, is reliant upon the same basic principles of humor in general; that is, just as a joke is only successful as a remark that elicits humor if its nature as a joke is understood, so too must self-deprecating humor be recognized as humor for itself to be funny, and for it to function positively as a rhetorical means of 
boosting a rhetor's character or working as an indictment directed at others when framed as an argument.

An ability to make fun of oneself, Morreall (1983) contends, need not bring upon negative perceptions of low self-worth; rather, he contends that such an individual "does not have an egocentric, overly precious view of his own endeavors. This is not to say that he lacks self-esteem—quite the contrary. It is because he feels good about himself at a fundamental level that this or that setback is not threatening to him" (p. 106). Indeed, framed correctly, self-deprecating humor can both increase a perception of humbleness while also concurrently establishing confidence in the eyes of the audience to whom it is addressed. A rhetor who uses self-deprecating humor can be seen as an individual who exudes confidence and believes that he or she can "afford" slights against him or herself.

\section{Self-Deprecating Humor as a Rhetorical Strategy}

The use of self-deprecating humor can be the result of a calculated effort to persuade individuals. By its nature of being "affiliative humor" (Hoption, Barling, \& Turner, 2013, p. 13), self-deprecating humor can be used to more readily bring those to our side. This, Duarte (2012) suggests, is crucial if one is to make a successful persuasion attempt (p. 21). We are, after all, more likely to listen to those in whom we see parts of ourselves and with whom we can thus relate.

\section{Self-Deprecating Humor in Practice}

To assess the rhetorical effect of the use of self-deprecating humor one must first take into consideration the quantifiable outcomes of its use. A successful use of selfdeprecating humor for a politician, for example, might be to ingratiate him or herself through the use of humor and to subsequently earn the audience's votes; for a teacher, the 
successful use of self-deprecating humor would result in capturing students' attention; a boss' use of self-deprecation would be determined as being successful if his or her employees gained respect for him or her and thus began to work harder under his or her supervision, and so on. Unfortunately, just as there exists a relative dearth of scholarship on self-deprecating humor in general, so too is the available number of studies assessing its use small in number. Nevertheless, what follows is a look at existing attempts to study self-deprecating humor.

In a Stocking and Zillmann (1976) study on disparagement humor, it was found that although men were who used self-deprecating humor were thought of by other men as being less intelligent, less confident, and in possession of a lower self-esteem compared to men who employed humor at the expense of others, women had a higher opinion of men who used humor to disparage themselves. This finding showcases the humbling effect of self-deprecating humor.

In terms of credibility loss, Chang and Gruner's (1981) study on self-disparaging humor found that self-deprecating humor which was aimed at a rhetor's profession or occupation can not only increase the perception of wittiness and sense of humor to a classroom audience, but that it can do so without harming perceived credibility. Thus, self-deprecation need not always harm those who make use of the humor. As a rhetorical strategy, the use of self-deprecating humor, Chang and Gruner's findings show, does not always confer negative perceptions to an audience. This finding flies in the face of much commonly extolled wisdom for professionals which routinely suggests that the use of self-deprecating humor can lessen one's standing.

Lundy, Tam, and Cunningham (1998) found that men who were already 
perceived as being physically attractive were viewed by women as more desirable after having used self-deprecating humor, though when used by men perceived as not physically attractive, the humor made no difference. Moreover, it was found that the humor increased desirability for attractive men for both short-term and long-term relationships. This finding seems to speak to that idea that self-deprecating humor, when evoked as a strategy by those whose appearance or position make clear that the selfdeprecating comments are made in jest, can be successful in a way it would not when used by those for whom such an intention is not as clear. Self-deprecating humor is, in essence, ironic; it is saying one thing, while meaning something entirely else. In this study, it might be said that physical attractiveness functions as I believe authority does in a rhetorical situation when self-deprecating humor is used. In both cases, something about the individual who uses the humor makes clear the irony of its use; in this study physical attractiveness perhaps conveys confidence, while the nature of authority itself implies a certain mastery, professionalism or confidence of its own. When such confidence is established to an audience, the true, intended nature of self-deprecating humor is made clear, an important facet of determining its successful use.

Results from a Greengrass and Miller (2008) study which compares perceived attractiveness of those who use humor that deprecates others versus the use of humor that is self-deprecating seem to affirm this correlation between perceived confidence and the desirability of self-deprecating humor. In the study, the researchers had individuals make audio recordings using either other-disparaging humor or self-deprecating humor. Participants of the opposite sex were then told to listen to the recordings and those whose recordings they listened to were described as being either high-status or low-status. The 
findings of the study showed that both men and women perceived those who were considered high-status and used self-deprecating humor to be more attractive for longterm relationships than were those who used disparaging humor against others.

Scholarship on self-deprecating humor has generally targeted its application in the context of an academic or organizational setting. In the context of academia, Frymier and Houser (2012) show that students benefit from interpersonal relationships being formed in the classroom between themselves and their teachers. Such relationships can be formed through a teacher's use of humor (p. 216).The researchers suggest that a teacher's use of such humor may result in a release of tension, anxiety, or stress which subsequently leads to better learning outcomes (p. 216). Like with other contexts involving authorities, students may not expect humor to occur in the classroom, and the resultant incongruence which takes place when it does occur can be a pleasant surprise for students (p. 217). Self-deprecating humor in particular can function to reduce the "vast status differential that frequently exists between teacher and student "(Korobkin, 1988).

In accordance with the principles behind the previously discussed incongruence theory of humor, self-deprecating humor will necessarily only be well-received if it is understood that its use is tongue-in-cheek. To that end, the appropriation of such humor should only occur when it is directed at an audience who understand the verbal irony in the statements. Thus, while such humor would be appropriate for teachers who instructor older students, its efficacy would be lost on those who are younger, and in such cases the humor may in fact damage credibility.

"Humor is a powerful weapon," says Jeff Nussbaum, a speechwriter who has worked for Al Gore and Joe Biden. "But to earn the right to wield it against others, you 
need to turn it against yourself first" (Beam, 2010). Beam's insight into the process of a political speechwriter as they pen comedy describes how politicians can best express goodwill to an audience by stressing their humbleness and ability to take a joke at their own expense. The use of self-deprecating humor by politicians is largely framed upon this premise. Perhaps more than any other authority figure, politicians are often perceived as being haughty and out of touch with those below them. The power they wield and the wealthy they often possess can serve only to distance themselves from their constituents. As it is in a politician's best interest to ingratiate themselves to constituents to earn their votes, it thus becomes necessary to work to lessen the distance that exists between themselves and others.

\section{Conclusion}

Existing scholarship on the nature of rhetoric, authority, and humor can all coalesce to explain how and why self-deprecating is appropriate, successful, and necessary when used by authority figures. Yet, thus far there has been little consideration into specific, documented instances of its use, particularly when it is used by noncomedians. Qualitative studies do exist which assess the efficacy of self-disparaging humor in some contexts (Chang \& Gruner, 1981; Hackman, 1988; Hoption, Barling, \& Turner, 2013), yet they fail to take into consideration its use in the context of persuasion and the specific situation in which it is used. Thus, a rhetorical analysis of such recorded uses of self-deprecating humor will provide insight into a facet of rhetoric that has hitherto been scarcely considered.

I submit that self-deprecating humor works when used by authority figures in a situation when humor is appropriate because it increases rhetor goodwill and, by 
consequence, lowers audience apprehension. Self-deprecating humor functions as a useful, successful means of lowering social distances which exist between authoritative rhetors and their audience by building the audience up as the rhetors bring themselves down. 


\section{CHAPTER III}

\section{METHODOLOGY}

In the previous chapter, rhetoric, social stratification, and humor were all presented and assessed as disparate areas of research. Yet when unified under the branch of self-deprecating humor as used by figures of authority, these three distinct topics inform how the phenomenon functions to both amuse and persuade. With an understanding of how and why self-deprecating humor may be used by an authoritative orator, it becomes clear why such humor comes into play in the political arena, as well as why its use merits a rhetorical analysis. In this chapter, I will first provide a background of the speakers whose self-deprecating humor I will analyze as well as their respective speeches which I will assess. I will then describe the close textual analysis, a means for scouring a text and interpreting its significance and meaning by scrutinizing certain words, phrases, or themes. Then, I will describe the White House Correspondents Dinner and detail its nature as a unique rhetorical situation in which rhetorical strategies which would otherwise be verboten may occur. After that, I will operationalize self-deprecating humor and detail the superiority theory of humor as the framework by which I will assess the rhetorical outcomes of self-deprecating humor in the texts. Finally, I will describe the specific methodology which I will use to analyze the chosen texts. 


\section{White House Correspondents’ Dinners Analyzed}

I have chosen to analyze WHCD speeches beginning with those given by Ronald Reagan. As established, Reagan was known for his employment of self-deprecating humor throughout his political career (In Weiler \& Pearce, 1992; Shirley, 2005; Hornick, 2011). This facet, along with the founding of C-SPAN (Cable-Satellite Public Affairs Network) which has covered the WHCD since 1993 and the spread of 24-hour news networks like the Cable News Network $(\mathrm{CNN})$ to propagate the speeches to a mass audience both of which occurring just before Reagan's tenure, make Reagan's speeches a logical starting point to begin the analysis.

Starting with Reagan, I chose one dinner from each presidential term for each of the four presidents I analyzed. I analyzed three of the four successive presidents who served after Reagan left office, ignoring George H. W. Bush owing both to a lack of available transcripts or video of his speeches as well as in the interests of maintaining a balanced representation of the figures chosen. Skipping Bush Sr., the four presidents whose speeches I analyzed were all two-term presidents and represent an even number of Republicans (Reagan and Bush Jr.) and Democrats (Clinton and Obama).

\section{Reagan}

For Reagan, whose terms were from 1981-1985 and 1985-1989, I have chosen the dinners from 1984 and 1986 as those whose respective speeches I analyzed. From his first term, Reagan's 1984 speech was significant because it was given during an election year, an election that he won handily, earning a record 525 electoral votes. This is significant because, as noted, Reagan made significant use of self-deprecating humor throughout the campaign, much to rival Walter Mondale's chagrin. For his second term, 
Reagan's 1986 speech came less than three months after the Space Shuttle Challenger disaster on January 28, 1986, an event which many (Cannon, 2011; Couch, 2011) consider to be a defining moment of his presidency, thus providing a major event which shadowed the speech and, consequently, an event by which to assess self-deprecating humor used in light of a serious issue.

\section{Clinton}

Bill Clinton's terms were from 1994-1996 and 1996-1999. Consequently, I have chosen the speeches he gave in 1994 and 2000 as those I will analyze. In 1994, Clinton was dealing with the so-called Whitewater scandal in which he was accused of illegal real estate dealings, giving his WHCD speech that year a controversy by which to analyze self-deprecating humor as a means to increase goodwill in light of media criticism. For his 2000 speech, Clinton was speaking as a man serving his last few months as president, having endured a savaging by the media as a result of the Lewinsky scandal and emerging with high approval ratings. A video that Clinton made was also presented during the dinner, called Clinton: The Final Days. This video will be analyzed and assessed as visual self-deprecating humor.

\section{Bush}

George W. Bush served from 2000-2004 and 2004-2008. I have chosen Bush's 2001 WHCD speech because it comes mere months after the controversial events during the 2000 election in which Bush won the presidency by a scant margin. As a consequence, how self-deprecating humor can be used to attempt to lessen schisms between party lines can be assessed during the 2001 speech

For this second term, the 2006 WHCD is especially significant because Bush's 
speech employed a unique comedic tactic which heavily employed self-deprecating humor--the use of a look-alike comedian to serve as Bush's “double." The comedian served as a representation of many of Bush's negative character traits perceived by the media and he featured heavily during Bush's presentation, and thus does the 2006 dinner serve as an excellent source by which to analyze self-deprecating humor when it is heavily at the forefront of a speech.

\section{Obama}

Barack Obama has served as president from 2009-2012 and 2012-2016. From his first term, I have chosen Obama's 2011 speech because, like Clinton's 1994 presentation, it came during a time when Obama faced criticism, that pertaining to the aforementioned “Birther" movement. Unlike Clinton's speech, however, Obama dedicated a significantly larger portion of his presentation to make light of the issue. Thus, the 2011 speech serves as an excellent text to assess the use of self-deprecating humor as a means to actually disparage and discredit others. As a consequence of the fact that Obama has served one year of his second term and thus attended only one WHCD during it as of the writing of this thesis, Obama's 2013 WHCD will serve as the second dinner I will analyze from his presidency.

\section{Close Textual Analysis}

I will perform a close textual analysis of transcripts available of WHCD speeches in which self-deprecating humor is employed. Textual analyses seek to scour a text for predetermined elements which are associated with persuasive purpose and, where they are found, establish intent and meaning. In the words of Leff (1986) a close textual analysis entails a search for those elements along with an explanation of "the interactions 
among [them]" (p. 378). Moreover, he contends, the focus of a textual criticism should be to "divert attention away from the theoretical constructions and to focus on the rhetorical action embodied in particular discourses" (p. 378). As a consequence, a textual analysis demands an assessment of the intended persuasive elements of the text. What was the orator attempting to get the audience to believe or do? Was the rhetoric sufficiently persuasive and, if so, what was it about the rhetoric employed which made it so?

\section{Self-Deprecating Humor}

\section{Self-Deprecating Humor as Rhetorical Ironic Discourse}

When used for a rhetorical purpose, self-deprecating humor is, at its core, a form of ironic discourse. One who uses self-deprecating humor to bolster an audience's opinion of him or herself is saying one thing, yet meaning something entirely different than what is actually said. Thus, the successful achievement of the intended rhetorical outcome of the use of self-deprecating humor is recognition that the self-deprecating statements are made in jest. Beyond simply acknowledge that a self-deprecating statement should not be taken at face value, an audience must also be able to analyze the joke and subsequently reinterpret its meaning. Using indicators like verbal inflection, situational context, an understanding of the rhetor's character, and the nature of the selfdeprecating joke itself, audience members are able to pick up on the irony of the joke and, as a result of the incongruence between the statement's surface meaning and its actual meaning, derive humor.

Here, Booth's (2007) method of determining whether or not a statement is given ironically serves the purposes of this analysis well: "If the author did not intend irony, it would be odd, or outlandish, or inept, or stupid of him to do things in this way" (pp. 52- 
53). We can assume, taking into consideration their position as president of the United States and putting aside all partisan considerations, that each of the presidents whose speeches will be analyzed have employed self-deprecating humor that is framed with an ironic intent.

\section{Superiority Theory of Humor and Humor as a Game}

As previously established, the superiority theory of humor (Ferguson \& Ford, 2008) posits that we may find humor in that which allows us to feel superior to others. The superiority theory of humor informs two key facets of the success and rhetorical utility of the use of self-deprecating humor and thus will it be used to provide a rationale for its use throughout the texts analyzed. First, the superiority theory of humor explains why an audience may laugh at jokes employed at oneself, particularly if one is in a position of power of others (as presidents are). Second, recognizing that they are in a position of power relative to their audience and understanding the potential negative character traits that such power may imply, the presidents' use of self-deprecating humor implies a recognition of the tenets of superiority theory which might allow those who laugh the ability to feel "above" the speaker.

Meyer (2000) asserts that superiority theory of humor has three rhetorical functions, of which two are important for the purpose of this analysis: identity and enforcement. Identification, Meyer suggests, implies identifying a speaker with their audience and building group cohesiveness (p. 318). Through the use of self-deprecating humor, the president makes light of flaws that are familiar to the audience—whether perceived or actual — and thus is meaning or perspective shared with the audience. For enforcement, Meyer suggests that humor may be used to encourage norms with a light 
touch, by way of criticism while still maintaining a connection with the audience (p. 320). This rhetorical function of superiority theory of humor can be associated with selfdeprecating humor when it is used as an argument. When used to levy attacks against others, self-deprecating humor is useful for it makes the attack seem less combative as a consequence of the self-mocking way it is employed.

Here, we may consider again Gruner's (1997) theory of humor as a game. If we agree with Gruner's belief that all humor is, in essence, a power play through the verbal tête-à-tête that is humor, we may recognize the use of self-deprecating humor as a willing acquiescence of power - in this case, a loss of some superiority or even perceived credibility which an authoritative rhetor can "afford to spare"- which in turn wins the self-deprecating rhetor an increase of perceived goodwill or a new way of making an argument that would not otherwise be possible. In this, the use of self-deprecating humor as a rhetorical strategy is the equivalent of "taking a dive" in a game, with the outcome being a loss of the game played, but a win in some other capacity not immediately obvious to the other players.

\section{Method}

\section{Presidential Image}

To begin with, I will take into consideration the perceived image of the president who uses the self-deprecating humor. Each president had his image well shaped by the media before even his first WHCD. However, such an image changes throughout his presidency. Such images will necessarily have an impact both on how the president delivered the speech, as well as the content of the speech itself. What kind of relationship did the president have with the media? What, precisely, was the image the media had of 
him? How did the president's image change throughout his presidency and how did that affect the speeches given? These questions must be answered to consider how imageboth the image consciously projected and that which is perceived—comes into play in the speeches.

\section{Self-Deprecating Humor Operationalized}

Next, each text will be analyzed for instances of self-deprecating humor. Instances of self-deprecating humor are those recognized as attempts to draw humor at the president's own expense. Examples of self-deprecating humor tropes include selfdirected jokes about age, physical characteristics, mannerisms, speech quirks, media portrayal, policy issues, controversies, intelligence, low approval ratings, and issues the president's own party happened to have faced at the time. Once found, each instance of self-deprecating humor will be analyzed by way of ascertaining the specific persuasive intent of its use.

As with assessing any other orator, it is crucial to assess the perceived desired outcome of the speech given, and by proxy, of the use of self-deprecating humor. Was the president using the humor as an argument? Was the humor used to bolster his image? Was the humor appropriated to lessen perceived distances between him and others? Was the self-deprecating humor used to quell or distract from an ongoing crisis? Answering the questions pertaining to rhetorical intent will aid in determining the success of the selfdeprecating humor employed.

I will also consider the specific nature of the self-deprecating humor used. In spite of its name, self-deprecating humor, though at first blush appearing to be critical of the one using it, may actually be used at times to serve as an attack against others. Consider 
the example of Barack Obama making a joke at his own expense about losing his birth certificate, a clear reference to the "birther" conspiracy theories which at one time had some traction in the media which suggested that he was actually born in Kenya; though ostensibly joking about himself, such an instance of self-deprecating humor actually served to disparage opponents who held such a belief. Further, Ronald Reagan had a penchant for making jokes at his own expense as a means of bringing down others as well, as evidenced by his dual joke about his own age and Mondale's during a 1984 presidential debate. In these situations, self-deprecation is a means of argument by taking perceived flaws, self-applying them, and disparaging those who perpetuate such flaws by belittling the comments through the use of over-exaggeration. As a consequence, selfdeprecating humor is multifaceted; sometimes it is used to create a more egalitarian situation between speaker and audience through the act of making light of oneself, while other times it is used to actually disparage others or their argument. Hence, the nature of self-deprecating humor employed is entirely situational.

\section{The Rhetorical Situation}

As Sillars and Gronbeck (2001) assert, a critic must necessarily look beyond the text itself and also consider the historical context in which it was produced (p. 10). Each of the presidents whose speeches I will analyze have had their fair share of controversies that are associated with their presidency, and it would be impossible to divorce their speeches from those issues. All presidential speeches given, irrespective of the content of the speeches themselves, are shadowed by these issues the given president facesscandals, controversies, war, public opinion, etc.- and thus will those be assessed with the respective WHCD speech analyzed, in adherence to Bitzer's (1992) aforementioned 
concept of rhetorical situation.

Each speech is inexorably linked to the political context in which it was given. Thus, a brief summary of the rhetorical context in which each speech was given will proceed the textual analysis of the speeches themselves when doing so will increase an understanding of the rhetoric used. Moreover, much of the humor used in the speeches is predicated on an understanding of political events and a familiarity with individuals well known at the time, and thus so too will an explanation be given for instances of selfdeprecating humor which demand a greater understanding of the political situation at the time of each speech to appreciate.

How the speeches fit within the context of the rhetorical situation in which they were given will be considered. A textual analysis demands, in Burgchardt's (2000) words, "[the] study [of] the relationship between the inner workings of public discourse and its historical context in order to discover what makes a particular text function persuasively" (p. 545). Questions which will guide my analysis will include: Is the use of self-deprecating humor more prevalent in certain rhetorical situations? In which rhetorical situation is self-deprecating humor most successful? Which tropes of selfdeprecating humor, if any, are more prevalent during certain contexts?

\section{Conclusion}

I will look at self-deprecating humor holistically throughout each of the presidents' speeches, analyzing each instance in concert with how it works to bolster his image, bolster an argument, disparage others, or ingratiate himself to his audience. I will also note instances of self-deprecating humor which is made in reference to specific perceived character traits or events which occurred. By looking at speeches from multiple 
eras and from presidents belonging to different political parties, I believe I will gain insight into how self-deprecation functions irrespective of partisan political considerations. 


\section{CHAPTER IV}

\section{ANALYSIS}

\section{Introduction}

In my analysis of the proceeding White House Correspondents Dinner (WHCD) speeches, I aim to interpret each presidents' use of self-deprecating humor as it used as a rhetorical strategy. First, I will detail the significance of the White House Correspondents' Dinner as a unique epideictic rhetorical situation. For each of the presidents whose speeches I will analyze-Ronald Reagan, Bill Clinton, George W. Bush, and Barack Obama-I will provide a brief introduction about them which will serve as a primer on their character and perceived image in the media. Following each of the presidents' introductions, I will perform a close textual analysis of transcripts made available of each of their two WHCDs assessed. I will search each transcript for instances of self-deprecating humor, which will be defined as any kind of humor which is made at the speaker's own expense, and I will interpret the humor as it fits as rhetorical strategy, taking into consideration the specific political context in which it was given. At the conclusion of each of the eight speeches, I will note prevailing trends and themes employed throughout the speech and explain their significance. As I perform each close textual analysis, I will make use of the superiority theory of humor (Ferguson \& Ford, 2008), edified by Gruner's (1997) theory of humor as a game in which there are winners 
and losers. I will also use Bakhtin's (1984) notion of the carnival as a means of explaining the unique rhetorical situation of the WHCD in which conventional social norms and expectations are temporarily suspended, allowing presidents to speak in a way in which they would otherwise be prevented by stifling traditional social mores. Upon completion of my analysis of the eight speeches, I will summarize my findings as they fit to explain the use of self-deprecating humor as a general rhetorical tool for an authoritative rhetor.

\section{White House Correspondents' Dinner}

\section{Why White House Correspondents' Dinners?}

To best understand how and why self-deprecating humor is appropriated by those recognized as authority figures, I will perform a rhetorical analysis concerning the use of self-deprecating humor by presidents speaking at a WHCD. I have chosen the dinners to analyze the humor because, since 1983, self-deprecation has consistently been a hallmark of the functions (Associated Press, 2002; Edwards, 2011). To be sure, self-deprecating humor is and has been used by politicians in other rhetorical situations, even well before the dinners began to be held in the early 20th century. However, the WHCD is a unique setting in that it is a recurring stage in which the humor is appropriated, making it an excellent source of texts to analyze because its use transcends political affiliation and the political climate in which each dinner is held. The consistent appropriation of selfdeprecating humor at each WHCD also speaks of its utility as a rhetorical strategy, for if speakers did not find value in its use, it would not continue to be used, much less would it be an expected occurrence as it is now. Simply put, at each WHCD, self-deprecation has become the norm. 
Each WHCD functions as a rhetorical environment somewhere between Bakhtin's (1984) aforementioned concept of Carnival and a jester's performance in a medieval court. It is clear during the dinners that the erstwhile stuffy, authoritative leaders are permitted — and, in fact, encouraged - to "let loose" and have fun in what should be a relatively informal setting. In this, the dinners serve as unique settings which allow for rhetorical interactions which are not otherwise possible in the humdrum day-to-day political realm. Yet the ostensible informality does not belie the fact that the dinners have now achieved a level of popularity such that they are covered through mainstream media and consequently reach the eyes and ears of Americans — and, indeed, the world—giving the orators an opportunity to persuade every bit as much as they may joke. This, then, is the value of the WHCD as a rhetorical avenue through which a president may persuade and thus is it an equally valuable situation to analyze.

\section{The White House Correspondents' Association \& History of the Dinners}

The White House Correspondents' Association (WHCA) was formed in 1914 and principally focuses on press access to the White House. Of the association's purpose, the WHCA stresses that it is an independent entity from the White House and "Consistent with the First Amendment, the White House Correspondents' Association stands for inclusiveness in the credentialing process so that the White House remains accessible to all journalists. We hope that individual episodes do not obscure the broader principles of a fair and evenhanded credentialing process that serves the goal of free and full exchange of information" (WHCA, 2014). The WHCA started hosting the annual WHCD in 1920 during the administration of Woodrow Wilson. Attendance at the dinners by a standing president began in 1924 when it was attended by Calvin Coolidge. Save for the 
occasional cancellation as a result of death, war, or other pressing issues of national importance, the dinners have been held annually, usually at the end of April, at the Washington Hilton hotel.

\section{The White House Correspondents' Dinner as an Epideictic Situation}

By its nature as a celebratory dinner, each WHCD can be said to be a situation in which epideictic rhetoric is performed. This belief is consistent with that tenets of epideictic rhetoric laid out by Condit (1985). Condit suggests that an epideictic speech will necessary include at least one of the following three functional pairs, and sometimes, a combination of them; definition/understanding, which Condit describes as using epideictic rhetoric's power to "explain a social world” (p.288), display/entertainment which focuses on a speaker's eloquence which she defines as being the "combination of truth, beauty, and power in human speech" (p. 290), and shaping/sharing of community which is defined by epideictic rhetoric's unique ability to unify groups of individuals through the building of a community (p. 289). Of the general hallmarks of epideictic, Condit suggests "Epideictic, it has been recognized, generally features colorful style, praise and blame, noncontroversiality, universal values, and prominent leaders and speakers" (p. 291).

In the context of a WHCD, it can be said that the average speech by an attending president fits within the purview of Condit's epideictic tenets. Through a president's speech, they are given the opportunity to define their presidency and the political issues faced, sometimes in response to criticisms levied through the media, the use of humor entertains the audience and showcases the president's sense of goodwill, and through the use of self-deprecating humor the president is able to capture the attention of both allies 
and rivals alike.

\section{The Presidents and their Speeches}

Though I will make the argument that recurring trends and themes exist when self-deprecating humor is made by presidents during each WHCD — and, consequently, that we can further apply these same trends and themes more broadly to explain the use and success of self-deprecating humor as used by any figure of authority in many rhetorical situations - it would be impossible to capture the nature and intent of each given president's use of self-deprecating humor without first understanding each president's image. This is so because, invariably, each president had his own image that was shaped by experience, party affiliation, and personal ideology. This image is not one that is merely self-applied or one given by others; rather, such an image is a combination of both self-perception and outside interpretation. Just as any other successful orator must consider both how he or she wishes to come off to his or her audience and how an audience may already perceive him or her, so too must all four presidents whose speeches I will analyze have taken into consideration the multifaceted nature that was their image.

By understanding how the presidents were seen by others and how they themselves wished to be seen, we may in turn understand how and why each speech was framed as it was, as well as the intended rhetorical outcome of the use of humor that was self-deprecating. Here we may again refer back to Amossy (2001) and his theory of prior ethos which, at its core, describes the perceived character a rhetor has before he or she steps up to the podium. It would be impossible to coalesce the full extent of an entire president's image into a single thesis, much less that of four presidents. Moreover, much of a president's image changes over time, especially upon reflection years after their 
presidency has ended. Thus, what follows is a brief assessment of each of the four presidents' image identifying each presidents' most defining traits and how they were seen—and how they wished to be seen—with an eye on their image as it was recognized contemporaneously with the speeches I will analyze. A textual analysis of the two WHCD attended will follow each respective presidents' image summary.

\section{Ronald Walker Reagan (1981-1984, 1985-1989)}

The date is October 28, 1984. It is the second presidential debate between President Ronald Reagan, the oldest president ever to have served in office, and Democratic nominee Walter Mondale. Mondale, having lobbed a litany of barbs at Reagan based on his advanced age and the subsequent insinuations about his inability to govern throughout the campaign, stands next to the 73 year-old incumbent when debate panelist Henry Trewhitt asks him if he believes his age is a factor which would impede his presidency:

You already are the oldest President in history. And some of your staff say you were tired after your most recent encounter with Mr. Mondale. I recall yet that President Kennedy had to go for days on end with very little sleep during the Cuban missile crisis. Is there any doubt in your mind that you would be able to function in such circumstances?

Reagan responds thusly:

Not at all, Mr. Trewhitt, and I want you to know that also I will not make age an issue of this campaign. I am not going to exploit, for political purposes, my opponent's youth and inexperience (The Commission On 


\section{Presidential Debates, 2012).}

The audience applauded, and even Mondale had no choice but to laugh along with the President's bon mot, remarking later: "Well, I'll tell you, if TV can tell the truth, as you say it can, you'll see that I was smiling. But I think if you come in close, you'll see some tears coming down because I knew he had gotten me there. That was really the end of my campaign that night, I think" (PBS, 2000). This is not the first time Reagan had employed such humor. Earlier in the year, when Mondale accused Reagan of running a "government of amnesia" (Weinraub, 1984), the President replied in kind: "I thought that remark accusing me of having amnesia was uncalled for. I just wish I could remember who said it" (Gamble, 2007).

Such remarks became something of a hallmark throughout Reagan's tenure, extending even to his attempted assassination in 1981, with the President remarking to surgeons about to operate on him after he was shot "Please tell me you're Republicans" and, upon regaining consciousness after his surgery, writing "I'd like to do this scene again—starting at the hotel” (Edwards, 2005, p. 99). Put simply, Reagan made consistent use of a rhetorical tactic which, at first blush, appears to fly in the face of conventional rhetorical strategies; Reagan took a perceived failing and, with adding a humorous twinge, "took ownership" of the flaw. Meyer (2009) suggests that Reagan also used humor to lessen perceptions of inferiority in his audience by suggesting that he was "one of them" (p. 85). His character established, Reagan could thus successfully use humor in a litany of other situations, like to "persuade about many controversial topics while maintaining a notably high level of goodwill from the public" (Meyer, 2012, p. 24). 
Ronald Reagan would go on to win re-election handily in 1984, receiving 525 electoral votes, more than any other candidate before him (Associated Press, 1985).When Ronald Reagan won his second term in 1984, he did so having earned what remains today a record amount of electoral votes. Reagan's victory over rival Mondale was so great in fact that he was a mere 35,000 votes away from winning the state of Minnesota (Mondale's home state) and sweeping all 50 states, what would have been a first for a president since the national popular vote tally was initiated (Congressional Quarterly, 1985).

To what did Reagan owe his tremendous victory? Like any president, a large part of his success can be attributed to the image he projected fitting with the zeitgeist, in Reagan's case, that of the 1980s. During the 1984 Presidential election campaign, the famous "Morning in America" campaign commercial Reagan's team produced perhaps best exemplifies the image Reagan sought to perpetuate as he made his re-election bid. The commercial, presenting an average morning for average Americans, emphasized optimistic gains in the U.S. economy since issues of inflation four years previous dogged Jimmy Carter's administration. The commercial, which positioned America as being "prouder and stronger and better” (Reagan-Bush ‘84, 1984) under Reagan’s leadership, placed him as being a man who could keep America just as strong against threats from within the country's borders, as he could from those overseas.

Reagan often used simple, laconic prose, leading one individual to remark that he was "the only politician [he] can understand" (Perloff, 2013, p. 288). Moreover, Reagan often spoke in language laden with patriotic symbolism which was optimistic and empowering (Perloff, 1998). This style of oratory contrasted with that employed by 
predecessor Jimmy Carter, who often used complex vocabulary and terminology that might not have been readily understood by those who were not keen on political or economic phraseology. In contrast to Reagan, Perloff (1998) suggests that Carter failed to capture a narrative the way Reagan subsequently did.

It can perhaps be said that much of his Reagan's success was also owed to his masterful construction of an image which resonated with Americans in the 1980s, helped in part by his Hollywood career decades earlier. Reagan, whose on-screen roles included All-American college football player George "The Gipper" Gipp (whose "win one for the Gipper" line would later become one of Reagan's own iconic phrases and would endure in successive Republican presidential candidates years after his own tenure ended) and a number of cowboys and gruff military men, coveted the image of a leader whose tough stand against those who would aim to do the country harm would keep America safe. This image was bolstered with great success by Reagan's Chief of Staff during his first presidential term, Michael Deaver. Friends with the Reagan family since Reagan's time as governor of California in the late 1960s and early 1970s, Deaver's emphasis on the president's image went beyond the symbolic and stressed the importance of a leader's physical appearance, his desire to have Reagan presented as on top of things at all times giving way to the now ubiquitous concept of the "photo-op" (Sullivan, 2007). That a president would take care to project a physical appearance which complimented his rhetoric was by no means a new phenomenon; yet it was during the Reagan administration that 24-hour news networks were established, creating an environment in which a president's image was shown worldwide with a frequency that was hitherto not possible. Reagan's position as a product of a new, more image-conscious media is 
perhaps best exemplified thusly: "John Kennedy introduced television to the presidency, but Ronald Reagan consummated the marriage" (Perloff, p. 109, 1998).

\section{April 13, 1984}

Ronald Reagan approached the 1984 White House Correspondents' Dinner in the final year of his first term as president. At the time of his speech at the dinner, Reagan had faced mounting pressure from the Democratic Party on issues ranging from foreign policy, the economy, to environmental issues as it worked to find a candidate to oppose Reagan in the approaching November presidential election. In particular, Reagan himself had been on the offensive against the media for a propensity to report on his policies with perceived unwarranted negativity, remarking in March of the year that the US economy was improving while "the coverage on network television was still in recession" and suggesting "1983 was a banner year for America, notwithstanding voices of pessimism which always found the single dark cloud in every blue sky" (Williams, 1984). This discord with the media would be an underlying theme throughout the speech.

To begin his speech, Reagan addresses the media on the question of whether or not he would remark about Walter "Fritz" Mondale, then clear frontrunner for the Democratic nomination for president for the year-end elections. In response, Reagan lobs a soft joke Mondale's way, with a reference to an Arpege perfume advertisement. Following up to the joke, Reagan retorts "I hope you'll forgive me-look, if some of these aren't funny, I asked Congress - they only gave me a third of all the ones I asked for" (Woolley \& Peters, para. 1, 1984). This bit of self-deprecating humor works to perform two separate duties; on the surface level, the joke was used as a defense 
mechanism for any response about that joke or future ones throughout the speech not being funny by showing a good-natured recognition that he, too, could commiserate with the audience about the quality of the jokes. In this, self-deprecating humor is leveraged to decrease Reagan's perceived position of power without compare and works to humble him. On the second level, Reagan's joke brings to light struggles he had with Congress, illustrating that, president or not, he himself still had failed to capture complete control of the situation, implying that those who dissented to his policies were not willing to cooperate and that he could not be blamed for their inability to reach a consensus. Here in the opening paragraph of Reagan's speech, Reagan uses self-deprecating humor to defend himself from potential criticism of joke quality, lessen the perceived social distance between himself and his audience, and to attack arguments about an inability to reach an accord with Congress. Reagan's first self-deprecating joke illustrates the multi-faceted nature of self-deprecating humor, as the rhetorical utility of the single joke extends beyond the surface-level attempt to make others laugh and instead works to preemptively defend against an attack, bolster his image and increase his audience's perception of his goodwill, and attack others.

Reagan continues, "But I hope you'll forgive me if I say that I'm filled with mixed emotions. I didn't know there were so many of you that couldn't get tickets to the Gridiron. And I appreciate your inviting me, but I do get a little nervous at a ceremony where the new president is replacing the old one" (para. 2). The Gridiron Club, much like the WHCA, is a journalistic organization out of Washington, D.C. which similarly has an annual dinner, at which Reagan himself had spoken. Reagan's comment about the audience being unable to attend the Gridiron implies that attending the WHCD was not 
the preferred, first choice, of speeches to attend this evening, diminishing the quality of the dinner and, as a consequence, representing a self-effacing comment about Reagan's own speech and the humor therein. By suggesting that he is their second choice, Reagan is lowering his standing relative to other speakers, a leveling act which increases his perceived goodwill because he is perceived to be more humble.

Of Reagan's comment about the new president replacing an old one, Reagan is making an obvious reference to his own re-election bid which was approaching. Reagan's joke shows a good-natured respect for his soon-to-be opponents by suggesting apprehension about the looming campaign. Reagan's use of the word "nervous" is an interesting one, as such a word is not one which most of his audience would expect coming from him, given the image of strength and staunch proponent of increased American military might which he cultivated throughout his political career. The selfdeprecating old president/new president joke humbles and humanizes Reagan, showing that powerful as he is, he is no more above such fears than anyone else in attendance. Once more, Reagan works to lessen the social distance between himself and audience members by allowing them to gain a kind of upper-hand at his expense - in this case, feelings of calm relative to his of unease - a crucial facet of the superiority theory of humor discussed by Gruner (1997) in the context of his game theory of humor which explains its utility and value as a means to ingratiate oneself to an audience that recognizes a disparity in power between themselves and a speaker.

Reagan continues, making reference to media criticism he has received: Incidentally, I know that some of you -- you talk a little bit, and you're critical about what you say is my 'living in the past." But I think that's because a lot of 63 
you don't just realize how good the old days were. You know, then you looked forward to seeing Lana Turner in a sweater, not Dan Rather. But you all have given me some problems at home. Nancy's taken to watching the press conferences, and now every time I answer a question, she says, 'I have a followup' (para. 3).

For his first self-deprecating joke in the third paragraph, Reagan recognizes a specific criticism lobbed at him regularly, that about his perceived grip on past values at the expense of contemporary, evolving ones, and makes light of them by referencing 1940s/1950s movie starlet Lana Turner in contrast to contemporary news anchor Dan Rather. Though Reagan does not supply any actual counter-argument to refute the charge, his joking response to the accusation in and of itself diminishes its potency. Through the use of a self-deprecating joke, Reagan simultaneously acknowledges the criticism by providing a humorous example justifying his stance, yet also determines that it is not a criticism worth acknowledging in a serious manner, lessening its efficacy as a rhetorical argument by detractors.

The next joke further acknowledges Reagan's perception that he was facing particularly tough criticism from the media, suggesting that his wife has now taken up the same criticism that the media spread. In contrast to his more active charge against media negativity documented by Williams (1984), this joke serves more to humanize Reagan, and acts as a kind of call-off-your-dogs-and-lay-off defense to the blowback he has faced. The joke appeals to something most members of the audience can appreciate—having a spouse and marital issues that ensue--and thus increases Reagan's relatability, a crucial rhetorical tactic consistent with Burke's (1969) notion of identification, or the idea that 
persuasion cannot occur unless both the persuader and persuadee can "identify" each other through the recognition of commonalities both parties share. When analyzed under the scope of the superiority theory of humor and Gruner's (1997) theory of humor as a game, Reagan's joke leverages his position of power and grants the audience a "victory" over him--Reagan the President of the United States becomes Reagan the henpecked husband--yet which in turn makes him more approachable as a person and thus, rhetorically, a more successful spreader of goodwill.

Continuing with references to media criticism he has received, Reagan continues: And I hear that Lesley Stahl has been asking if anything can be done to improve my answers. Yes, ask better questions. But do you know what it's like to have Chris Wallace and Bill Plante screaming questions in your ear when you're only about 10 feet from the helicopter with the motor roaring, and you realize they're asking, 'What's wrong with your hearing, Mr. President?' (para. 4). Reagan's first joke references the perception that Reagan had a penchant for providing non-committal or otherwise obfuscatory answers to questions from media outlets. Acknowledging that his answers may in fact be lacking in terms of content on occasion, Reagan turns the joke around and places the onus on the media themselves for the perceived low quality of the answers he has given, absolving himself from the charges. Like his previous self-deprecating jab about his emphasis on living in the past, Reagan here uses self-deprecating humor to both seemingly acknowledge the indictment, enhancing his perceived goodwill by making him appear as though he is not above reproach in terms of responding to criticism, but also dismisses the charge by placing the blame for his behavior elsewhere. Once more, self-deprecating humor is used as a 
deflection of an argument by simultaneously "owning" it while also laughing it off, lessening its rhetorical efficacy as an attack on his character.

The next joke makes reference to Reagan's older age. As the oldest sitting president, Reagan had faced much criticism about his age, including his physical wellbeing, evidenced by the aforementioned charge and self-deprecating reply made by Reagan during his debate with Mondale which took place months following this speech. With his self-deprecating joke about his hearing, Reagan references an occupational "hazard" - that of a president's frequent transportation by helicopter-and uses it to respond to criticism making light of his age. The quip positions his day-to-day activities as being necessarily ones which would, at times, impede certain physical faculties, making something like references to Reagan being hard-of-hearing as being not an issue of age, but rather one that is just the result of presidential duties.

Remaining on the tangent about his portrayal in the media, Reagan continues, "The other day the Washington Post ran a story heralding the return of spring, and I thought it was just another one of the reports on the political campaign. The headlines said, ‘The Sap Is Running Again"' (para. 5). Reagan's joke illustrates how Bakhtin’s (1984) notion of the carnivalesque describes that of a WHCD; in any other context, a president would generally not be expected to disparage himself, especially not in reference to an upcoming re-election bid. In such a situation, the expectation is that a president would bolster his or her image relative to the competition, highlighting the very best of his or her character and the positive perceptions others have to increase a perception of ethos, not bring to light media criticism. Yet here, Reagan does precisely that, making use of the unique rhetorical situation of the WHCD to act in what would 
otherwise be a subversive manner for a head of state. This joke works to actually boost Reagan's character, as it illustrates a strength of character which can endure in spite of such criticism.

Reagan continues:

You know, I think it's interesting -- your new president's been out covering Gary Hart, and I understand that he's come up with yet another new idea about the future: Avoid Roger Mudd. Every time he thinks about that interview, Ted Kennedy's entire life flashes before his eyes. He got so rattled with some of Roger's questions that he gave his right age. And of course, about that name thing -- the other day he said that the name, as far as he knows, goes as far back as the Revolutionary War. Well, I wouldn't know about that far back, but I do feel that I remember running across somebody by the name of Hartpence at San Juan Hill (para. 6).

San Juan Hill was a major battle in the 1898 Spanish-American War in Cuba, making Reagan's reference a ludicrous one were the audience to take it on its face value. Such a joke emphasizes self-deprecation as a style of humor deeply entrenched in irony; Reagan is operating on the assumption that his audience is well aware that what he says is inaccurate, but what is more, that the nature of the comment as a joke distinguishes its inaccuracy from what would otherwise be perceived as an ethos-damaging lie. Once more, Reagan makes reference to his older age and the perception which would endure throughout the year that he was too old to run again for president, an argument which would not be quelled until his disarming age joke made in November of the year during the aforementioned Reagan/Mondale debate. The Battle of San Juan Hill was a large 
success for the United States and the Cuban insurgents who fought on its side, granting then-commander Theodore Roosevelt and his Rough Riders considerable fame in the press and eventually propelled Roosevelt to his presidency. In his joke, Reagan combines self-deprecation with a reference to a major military campaign which preceded the United States' eventual victory in the war, establishing him as being self-deprecating while also evoking feelings of pride and patriotism in his audience. That he would make reference to the battle is not a coincidence; for Reagan, whose emphasis on updating and enhancing America's military might_ - particularly with an eye on surpassing the Soviet Union—was one of his enduring campaign promises during his first presidential election bid in 1980, had long been a proponent of America's commitment to peace through superior firepower. Once more, Reagan has no problem acknowledging a perceived flaw and matching it with a jocular non-sequitur.

Reagan continues to make light of his age with the next joke, "You guys and gals are always trying to pin me down as to which candidate worries me the most -- Mondale, Hart, or Jackson. None of those. The guy that scares me is Governor Dick Lamm" (para. 7). Governor Dick Lamm had incited controversy at the time of Reagan's speech by arguing that the elderly and terminally ill should not prolong their life by artificial means, proclaiming earlier in March of the year "We've got a duty to die and get out of the way with all of our machines and artificial hearts and everything else like that and let the other society, our kids, build a reasonable life" (Associated Press, 1984). At this point in his speech, Reagan has already made four easily identifiable self-deprecating references to his age. This repetitious emphasis on age is used as a means of taking it off the table for the media; it is, in a sense, an act of rhetorical dilution. Reagan's self-directed barbs 
referencing his age once more grants his audience a kind of victory that Gruner (1997) speaks of when positioning humor as a game — by acknowledging the charges and raising the proverbial white flag of surrender-yet he comes out all the better because, in spite of his age, he still manages to endure and fight on. With age, there is the expectation of intellectual diminishment and a loss of oratorical savviness, yet Reagan's rapid-fire selfdeprecation flies in the face of conventional age-based stereotypes regarding his ability to stay toe-to-toe with others. Moreover, by inundating his speech with references to his age, Reagan also takes away some power from the media and rivals who hope to make age an election issue for him, for it is difficult to derive humor from a trait a person possesses when that person is already the first to make a joke about it.

Reagan continues, dropping the age issue and focusing instead on job stability, But I've been enjoying this, and yet sometimes I find myself thinking about what it would be like to have a steady job with real job security, like managing the New York Yankees for George Steinbrenner. You've got to be a baseball fan to get that one. They're in and out in 3 weeks (para. 8).

The absurdity of the joke, of course, is, as Reagan points out, that managers for the New York Yankees have had a particularly tough time staying employed in their position. In turn, Reagan's comparison between his own job and that of being under the employ of team owner George Steinbrenner once again highlights apprehension of the looming 1984 presidential election. As with Reagan's first joke about the impending election, Reagan once again uses self-deprecation to highlight his own anxiety, although this time he does so in a manner that appeals to a more specific group of people in the audience. Reagan, a former radio announcer for the Chicago Cubs major league baseball 
team, uses the sport's reputation as being an American institution (illustrated by the cliché of referring to something quintessentially American as being "American as baseball and apple pie") to reach his audience. Even those who do not understand the joke at first are made aware of its significance upon Reagan's explanation, and those in the audience would doubtlessly be aware of baseball's status as an inseparable facet of Americana, irrespective of how keenly they are familiar with the ins-and-outs of the sport itself. As a president who fashioned his campaign around an appeal to old-fashioned American values (sometimes, to the point of drawing criticism from detractors, as evidenced by the earlier Lana Turner/Dan Rather joke in paragraph 3), this form of selfdeprecating humor also boost's Reagan's character as a paragon of conservative American values.

After issuing a barb against Colorado senator and potential Democratic nominee for the presidential election Gary Hart on the issue of a balanced budget, Reagan once more brings up the issue of media negativity,

But, you know, I just don't understand those guys that are bellyaching about the economy and trying to make out that everything is so bad. Inflation is down. Taxes are down. Unemployment is down. Productivity is up. So, what's the beef? And what's all that talk about a breakdown of White House communications? How come nobody told me? Well, I know this: I've laid down the law, though, to everyone there from now on about anything that happens, that no matter what time it is, wake me, even if it's in the middle of a Cabinet meeting (para. 10). As addressed previously, Reagan perceives detractors in the media to be dogging him unfairly, particularly in the face of optimistic data in line with campaign promises he 70 
made about improving the economy. Reagan again attempts to diminish the efficacy of the criticism on his credibility, this time making reference to the then-popular "Where's the Beef?" advertising campaign for the Wendy's fast food chain. Reagan continues, referencing media criticism about a perceived breakdown of communications in the White House by jokingly admitting to the validity of the criticism, although in a way that it is obvious that he disregards the charges. Here, again, Reagan "tables" the criticism by rendering it as a topic which merits derision; he acknowledges it as an issue people are discussing, painting him as someone not afraid of the charges, but with a simple quip refutes its status as a legitimate grievance. The last self-deprecating joke makes reference to rumors that Reagan would fall asleep during meetings with White House officials. Once more, the carnivalesque nature Bakhtin (1984) described and the characteristics of it which this WHCD shares is clear; Reagan is speaking in such a way that he would not dare in another situation, a manner of acting which is consistent with the second of Bakhtin's four categories which he describes makes up a carnivalesque situation, that of eccentric behavior, or that which would be deemed inappropriate from an individual of Reagan's status in any other context. Individuals, irrespective of political leaning or party affiliation, would almost certainly find someone who willfully acknowledges falling asleep on the job to be ill-fit to work at a retail job, much less fill the position of leader of the most power country on the planet. Divorced from such a unique setting where roles are relaxed if not totally violated, Reagan's comments would be widely perpetuated as a detriment to his character, even if it was obvious that they were given in jest, especially in an election year. Yet for a speaker at a WHCD, where there is the expectation that comments made by presidents will be humorous in nature, Reagan's joke actually 
enhances his character, making what would otherwise be a fairly damning charge merely an amusing character quirk.

Reagan's last two self-deprecating jokes during his speech make further reference to unflattering media portrayals of his presidency and the state of the White House in general

Another thing that needs taking care of are the leaks. And we're really going to get ahold of those. Already I have ordered that we get rid of all those White House memo pads that have a notation on the bottom of each page that says, 'Courtesy copy: Lou Cannon, Steve Weisman' (para. 11).

And by the way, why are you all so willing to carry the bad news about the administration? Now, you all did stories about the Vice President taking a dive at the bowling alley, but no one mentioned that he knocked down nine pins. And if he had slid just a little further, he'd have caught the 10th one with his head. 'Bowling for Dollars' wants him to do a guestspot [sic] (para. 12).

In paragraph 11, Reagan dismisses the idea of media leaks being failings of the administration itself, associating the claim with the absurd idea that all White House memos would automatically be sent to Lou Cannon and Steve Weisman, two notable members of the press. Again, Reagan uses self-deprecating humor to save face by placing blame for indictments faced on another party, away from himself and his own staff. Reagan finishes in paragraph 12 by once more referencing media negativity, referring to an inoffensive recent event related to the Vice President the media covered, with a bit of good-natured ribbing at the VP's expense. The background of the specific event referenced was inherently humorous in nature, and the last line of the paragraph makes it 
even more light-hearted, making Reagan's own indictment at the media's expense more seemingly playful and less aggressive than other recent issues perceived to have been covered with a negative perspective. Rhetorically, this functions as a final attempt to enhance his perceived goodwill, letting his audience know that he is not being too hard on the media, a crucial point to emphasize given that his audience is composed of members of the very same media for which there is mutual animosity.

Reagan finishes his speech thanking the audience and expressing the value of what the audience — the media—does in spreading the truth and, by virtue, how their actions benefit freedom in America. Reagan attests that the American people rely on the media, and affirms the importance of what they do. That Reagan finishes a speech ripe with self-deprecating humor with a message of sincerity and earnestness serves to reentrench Reagan in his position as president by speaking in a manner that is more consistent with that generally expected from commander-in-chief, with appropriate gravitas and solemnity, separating himself from the previous carnivalesque nature of the speech, and returns to the status quo.

In sum, Reagan's 1984 WHCD focused on two of the most salient issues which perhaps most stood to impede his hopes for re-election later that year. The first, his advanced age, was broached by thoroughly refuting the perceived impact his age may have had on his ability to govern, largely by approaching the issue directly. As we have established, with age comes perceptions of infirmity, slowness, and caution. The last two qualities in particular were those Reagan, take-charge, Cold Warrior, would have been eager to disabuse. Through his use of self-deprecating humor, Reagan was afforded the ability to recognize the claims about his age that others were making, while doing so in a 
way that affirmed that he was above them. That is, Reagan's very act of acknowledging his perceived old age and mocking himself about it showed that he was every bit as able to keep up with his opponents and, by virtue, meet the rigorous demands of the presidency.

The second issue which dogged Reagan, that of media negativity, was likewise touched upon through self-deprecating humor in a way that allowed him to discuss it without being too aggressive or without giving off the perception of overt defensiveness as he responded to critics. Though taking his critics to task over their claims, by doing so in a way that was self-deprecating in nature, Reagan was able to do so without coming off as preachy. Like flavoring otherwise bitter-tasting children's medicine with a sweetening ingredient, using self-deprecating humor as one also indicts others and allows one to attack with a smile. That said attacks happened to come during jokes made ostensibly at his own expense worked to position Reagan as being less caustic and bitter as he made his argument, contrasting heavily with the typical sentiment associated with negative political discourse.

\section{April 17, 1986}

In response to the April 5, 1986 bombing of a Berlin nightclub commonly attended by American soldiers which resulted in the death of three, including two American servicemen, Ronald Reagan ordered a retaliatory strike on Libya, which Reagan claimed was complicit in the act of terrorism. The military strike, which took place on April 14th, three days before Reagan's WHCD speech, was justified as a necessary and just action in the face of Libyan leader Muammar Gaddafi's purported role in the actions against the U.S. In his address to the nation, Reagan remarked "Today, we 
have done what we had to do. If necessary, we shall do it again. It gives me no pleasure to say that, and I wish it were otherwise" and stressed the evidence linking Gaddafi's regime to the bombing (Reagan, 1986a). The military strike was widely condemned around the world (Davidson, 1986; Ruimy, 1986; Couch, 2011), particularly by countries in the Middle East and by the Soviets, who maintained that the act would serve only to exacerbate the situation in the Middle East.

Beyond controversy elicited from the recent military action in Libya, Reagan also faced blowback domestically from House Democrats who rejected Reagan's attempts to provide funding for Nicaragua's Contra rebels. In response, Reagan described the opposition's actions as putting "the lives of countless young Nicaraguans in jeopardy" and suggested that they represented a "verdict of shame on us all" (Boyd, 1986). Thus, Reagan entered the 1986 WHCD facing scrutiny in the media the nature of which was appreciably more tense that that which he had faced entering the 1984 WHCD in his first term as president.

Reagan begins his speech by making a joke about a fictitious "Kremlin Correspondents Dinner" which he suggests is currently occurring in Moscow, where media are required to laugh at Gorbachev's jokes “or else”(Woolley \& Peters, para. 1, 1986). In the second paragraph, Reagan immediately makes reference to one of the albatrosses in the room, that of the aforementioned Nicaragua situation. Reagan references Nicaragua president Daniel Ortega, whose Marxist-Leninist leanings and association with the Sandinista National Liberation Front draws his ire and is responsible for much of the controversy he is facing both from domestic critics as well as those abroad. 
You know, I rehearsed my lines in front of Don Regan, and I asked him if he thought my — how my timing was, and he said, 'Almost as good as Daniel Ortega's.' He said that I was supposed to get up here and make the press laugh. Well, there's nothing I like better than a challenge—like making people laugh just 2 days after April 15th (para. 2).

Reagan's first self-deprecating joke of the night resembles his first given during his 1984 WHCD speech. In both cases, Reagan has associated a current issue he is facing while making a self-critical comment about his joke-telling abilities. Rhetorically, this serves as a preemptive defense in two fashions; first, at its most obvious level, Reagan uses the tried-and-true method of using self-deprecating humor to insult himself about something before others could, thereby having a sort of peremptory "control" over the charge and thus, diminishing its negative effect. Reagan is seeking to gain goodwill from his audience immediately and by making fun of his own jokes, he works almost to apologize about them before others could scold him for one. Similarly, by addressing an issue whose prevalence makes obvious that it is on the mind of his audience, Reagan takes charge of the situation and establishes a kind of control. This works to enhance the image he covets of being a fearless and take-charge kind of individual. This image was on display most recently during his aforementioned address to the nation days previously about the strikes against Libya when he attested "[Gaddafi] counted on America to be passive. He counted wrong. I warned that there should be no place on Earth where terrorists can rest and train and practice their deadly skills. I meant it. I said that we would act with others, if possible, and alone if necessary to ensure that terrorists have no sanctuary anywhere" (Reagan, 1986b). 
Reagan also works to establish a commonality with the audience as he did when referencing his wife during his $1984 \mathrm{WHCD}$, this time by bringing up an issue everyone in the audience, irrespective of their position, had to face - taxes. Longtime opponent of high taxes, Reagan acknowledges the general disdain most have for Tax Day by commiserating with the audience, for all intents and purposes saying, "I understand, and I feel for you." Reagan here is working to draw the audience on his side and lessen the distance between them and himself by harkening to an equalizing facet of life for which all have to deal. Moreover, because most have negative feelings about taxes, something like Tax Day becomes an acceptable target, lessening the risk that anyone in the audience would be offended by the joke. Adhering to Gruner's (1997) thesis, such a joke grants the audience a "win" over an institution, although in a way in which Reagan is not perceived as being overly aggressive, owing to the almost universal disdain for taxes, which allows Reagan to retain a sense of goodwill and amiability. The audience, diverse as it is, resides within the "in group" for which the joke resonates and as a consequence, the joke unifies speaker and audience (Gruner, 1997, pp. 78-79). In this, Reagan is positioned as "one of us," a tax-paying (and tax-hating) schmo just like everyone else.

On the subject of the issues Reagan has recently faced, he continues, Those last few weeks have really been hectic what with Libya, Nicaragua, and the budget and taxes. I don't know about you, but I've been working long hours. I've really been burning the midday oil (para. 4).

Though the issues he addresses are generally those that he and not his audience has to face, Reagan makes them universal issues through his unifying phrase "I don't know about you...", taking the heat off of himself for criticism he has faced about his 
handling of those issues by spreading the responsibility around. His joke about the "midday oil," on the other hand, continues a recurring trend of making self-deprecating light about his age. Given that the joke comes right after referring to multiple major, pressing issues he and the country are facing, Reagan's use of self-deprecation works to remove some of the gravity of the events and to boost audience perception about how he has been handling them by increasing his goodwill. Once more, as was the case often in his use of self-deprecating humor during his 1984 WHCD, Reagan is using selfdeprecation to deflect criticism by emphasizing his own strength of character. When Reagan employs self-deprecating humor on the subject of a crisis he is facing, he is moving attention to himself. The nature of self-deprecation, after all, focuses on the self. Almost as an act of contrition in response to issues that are insinuated, Reagan mocks himself; this, in spite of the fact that the issues themselves are not actually addressed. Reagan continues on the same age-related tangent in the next paragraph:

You know, I received an invitation that said, 'Please come to Ellis Island July 4th for the hundredth birthday celebration of an American institution.' Somebody goofed. My birthday isn't until February. And it really won't be my hundredth, although I've been around for a while. I can remember when a hot story broke and the reporters would run in yelling, 'Stop the chisels!' (para. 5).

Once more, Reagan makes references to his older age. As with the San Juan Hill age joke and to a lesser extent the New York Yankees manager job joke Reagan used in his 1984 WHCD speech, in this example Reagan uses self-deprecating humor which is associated with an American institution. Here Reagan uses a joke at his own expense by once more making reference to a well-known symbol of America, in this case the 100th 
anniversary of the installation of the Statue of Liberty, known the world over as a beacon of America's proud history of immigration. This joke thus appeals to something for which all the audience is familiar, not only making light of his age, but also referencing an upcoming event which represents unity, and is decidedly non-partisan. In the next line, Reagan outright acknowledges the fact that he is older, although again does so through a good-natured display of an overtly over-the-top, humorous way which makes obvious that he is not really that old. By jokingly implying that he is old enough to have been around when reporters conveyed news on chiseled stone, he again downplays the actual charge through the absurd, incongruent mental image it evokes.

You know, I do follow what you write. One of you just recently wrote a piece questioning why things seem to be going so well for me lately. Well, it's just a case of letting Reagan be Regan (para. 10).

The Regan to which Reagan refers in the 10th paragraph of his speech is White House chief of staff Donald Regan. Proponent and spokesman of the so-called "Reaganomics" economic policies, some in the media have suggested that Regan is really in charge of the White House, implying that he wishes to be the "prime minister" to Reagan (Geyelin, 1985) and that he is "firmly in charge" of the administration (Brode, 1986). With this self-deprecating rejoinder, Reagan is making reference to his belief that the media tend to cover him with undue negativity. Here, Reagan, well aware of the criticism that Regan has more control over Reagan's own policies than he should, takes a swipe at the media's recent commentary on the lack of negative news on which to report by placing the success on Regan. Like with many of his other uses of self-deprecating 
humor, Reagan is acknowledging criticism, using hyperbole and absurdity to delegitimize the arguments, and thus rhetorically "conquering" them. Because he uses self-deprecating humor to do this as opposed to being overly aggressive and using other-oriented attacks and refutations, Reagan maintains a sense of benevolence and positivity to his audience. In that sense, Reagan appears "above" the references, pleading through self-deprecation that he is more humble, and earnest than are his detractors.

The jokes in paragraph 10 would represent Reagan's last uses of self-deprecating humor during his 1986 WHCD speech. In the next paragraph, Reagan makes a joke at the expense of Congress and their purported collective lack of intelligence. In paragraph 12, Reagan references comic and television host Dick Cavett who is slated to speak after him and does so by complimenting Cavett's intelligence. Finally, in paragraph 13 Reagan makes a joke about the new WHCA president Bill Plante.

Reagan concludes his 1986 WHCD speech much like he did in 1984: with an expression of gratitude for the audience and a sense of sincerity. Reagan acknowledges the occasional discord between himself and the media (in his words, he refers to the relationship as being "disputatious now and then" (para. 14) but thanks them for what they do for helping maintain freedom at home and abroad. As he does this, Reagan makes reference to the actions in Libya and salutes the Air Force and Navy members involved in the excursion. In the final paragraph, Reagan praises the effects of laughter and patriotism expressed during the dinner and thanks those who attended.

Unlike the 1984 WHCD, in 1986 Reagan expressed a relative paucity of selfdeprecating humor. Given the recent events Reagan was facing, particularly in terms of media criticism, it could be argued that Reagan did not wish to draw much attention to 
perceived flaws as he was wont to do in 1984 . Facing greater media scrutiny and congressional discord than in 1984,1986 represented a more trying time for the president. To make best use of self-deprecating humor as a rhetorical strategy to enhance character, marginalize arguments faced, or make arguments of one's own, a rhetor must already find him or herself in a position of power relative to the audience.

The nature of the struggles Reagan faced were largely those owing to actions of individuals overseas as a result of major policy issues, thus taking away much of Reagan's agency in those situations. As a consequence, Reagan was not afforded the same kind of latitude to self-criticize as he would have been had the issues he faced been more reliant on simple superficial character traits. Self-deprecating humor, at its core, is not well-suited to defend against arguments that are steeped in major controversies faced. It is thus no coincidence that Reagan's general go-to topics of self-deprecation—his age, his coverage in the media, his job security, general political rivalry, and so on-were those which were relatively innocuous compared to issues relating to armed conflict, political scandals, and U.S.-backed rebels overseas, all other salient issues Reagan faced at the time of the WHCD. In this, self-deprecating humor is indistinct from humor in general as a rhetorical tool; simply put, there are some topics and contexts which do not serve as appropriate situations in which to launch jokes.

Within both of Ronald Reagan's WHCD speeches the self-deprecating themes he employed remained more or less consistent. Jokes about his age were prevalent across the two speeches, often exaggerating his age to such a degree that those who might themselves levy criticism against Reagan based on his age were essentially beaten to the punch and topped by his hyperbole. Through his use of age-based self-deprecating 
humor, Reagan made absurd, blatantly over-the-top associations of his age (Implying he took part in a military campaign in 1898 , suggesting that he was nearing his 100 th birthday, attesting that he feared being taken off of life-support by a senior's right-to-die activist, and so on), thereby associating any further indictments against his age with the same absurdity he employed at his own expense. In essence, such jokes worked to both defend his ethos by assuring his audience that criticism about his age was unwarranted, as well as to increase his standing by showing that, though the media perception of his age lacked merit, he was nevertheless willing to indulge the charge with good-natured, selfdirected ribbing.

Reagan's media portrayal was also a continuous source of his self-deprecating barbs in both speeches analyzed. Beginning his 1984 speech with a response to the media and continuing through both speeches until the penultimate paragraph of his 1986 presentation, Reagan openly acknowledged the oftentimes contentious relationship which existed between himself and the media. If his self-deprecating jokes about his age were largely defensive, his ostensibly self-oriented jokes about his portrayal by the media functioned primarily as retorts against others. The language he employed in otherwise self-deprecating jokes about how he was covered in the media often identified undue negativity they had for him, and appeared accusatory (“...you talk a little bit and you are critical about what you say is my living in the past..."; "I hear that Lesley Stahl has been asking if anything can be done to improve my answers"; "I just don't understand those guys that are bellyaching about the economy and trying to make out that everything is so bad"; “...why are you all so willing to carry the bad news about the administration?”; "You know, I do follow what you write. One of you just recently wrote a piece 
questioning why things seem to be going so well for me lately."). Such self-deprecating jokes allowed Reagan to address the ubiquitous criticism while maintaining a sense of goodwill owing to the ostensible self-directed nature of his humor. Because he responded to media criticism by labeling it as being primarily negative, Reagan was able to come out as a more positive, optimistic leader, diminishing the pessimistic charges.

That Reagan's second WHCD speech analyzed was given during a more turbulent time for the president perhaps best explains the relative dearth of self-deprecating he used within it compared to its ubiquity in his 1984 speech. Because he faced greater scrutiny from the media and the public than he did in 1984, Reagan would not have wanted to draw more attention to perceived flaws, regardless of how relatively innocuous they would have been. There is a time and a place for self-deprecating humor, and though the WHCD in which he spoke was the appropriate place, the context in which he gave his speech determined that it was not an especially appropriate time.

\section{William Jefferson Clinton (1993-1996, 1997-2000)}

If Ronald Reagan was the stalwart, authoritative paterfamilias perpetuating the old guard of classic American values through the then nascent CNN, Bill Clinton was, in many ways, the hipper, more accommodating brother of the MTV generation who matched the rapidly changing cultural landscape with an eye towards progress and evolving values. Raised by his grandparents (his father died 3 months before he was born and his mother left for work when he was young), Clinton's upbringing carried him from small town Arkansas, where he would learn from a former childhood playmate that he was "the only white boy in the neighborhood who played with black kids" (Clinton, 2004, p. 12), to the University of Oxford with a Rhodes Scholarship. 
Clinton's victory in the 1992 presidential election saw the end of what had until then been 12 years of uncontested Republican rule in the White House, extending from Ronald Reagan's first year in office in 1981 to George H.W. Bush's last year as president in 1992. Clinton framed his election campaign as one of vigor and renewal, describing his newly-won presidency as representing a "new beginning" for America (BBC). Entering office at age 47, Clinton represented youth and exuberance which contrasted with previous presidents Reagan and Bush Sr. before him, who were 77 and 68 respectively at the end of their last full year of their presidencies. This image was bolstered by his famous love of the saxophone, a proclivity for fast-food, and an appearance on MTV for his own special, Choose or Lose: Facing the Future with Bill Clinton, which provided young people a forum to ask then-governor Clinton questions on everything from sex education, gay rights, to "If [he] had to do it over again, would [he] inhale?" referencing an earlier comment he made about having smoked but never inhaled marijuana ("Sure, if I could" Clinton replied, "I tried it before") (Clinton, 1992). In subsequent years, Clinton would acknowledge the value of his appearance on the special, remarking "I think everyone here knows that MTV had a lot to do with the Clinton/Gore victory" (Paley Center for Media, 2011).

Time.com would later refer to Clinton as having been "thoroughly modern" and a "natural ally of the MTV generation" (Fastenberg, 2010). This retrospective interpretation is entirely consistent with the image the media had of Clinton during his presidency. A New York Times piece published during Clinton's campaign for presidency perhaps sums his image at the time of his election most effectively:

Addicted to card games of hearts, golf and crossword puzzles, a whiz on the tenor 84 
sax, Clinton has the look and loosey-goosey enthusiasm of a high school jock perched somewhere between eternal youth and paunchy middle age. But he also has the natural ease of a born politician -- touching, hugging, making eye contact so deep that recipients sometimes seem mesmerized. Tabloid rumors aside, Clinton embodies the parallels between the seductions of politics and the seductions of sex. As one Clinton watcher said recently: 'It's not that Clinton seduces women. It's that he seduces everyone' (Applebome, 1992).

Clinton, like Reagan before him, coveted an image which resonated with the times. With the Iron Curtain drawn back, however, the issues most salient to Americans had changed and thus Clinton worked to distance himself from the perceived rigidity of the American values espoused by his Republican predecessors. Described by The Christian Science Monitor as being the "brother president" (Feldmann, 1997), Clinton managed to straddle the line between highly-educated, esteemed do-gooder and approachable, casual figurehead, for the benefit of a generation that had come to recognize the presidency as representing a new, less stodgy, more equitable position.

Clinton's perceived image was one which he carried with him throughout all eight years of his two-term presidency, enduring even during the Monica Lewinsky scandal and subsequent impeachment proceedings he faced. During the summer of 1998 when Clinton was dogged by the media concerning allegations that he had been in an inappropriate relationship with Lewinsky, Pulitzer Prize winning author Toni Morrison defended Clinton against the charges, controversially referring to him as being the "first black president" by associating his "common man" traits with those generally possessed by the average Black American and, consequently, equating the media shaming of 
Clinton as being similar to that which Black Americans face from the media. Morrison's summation of Clinton's perceived image during the Lewinsky scandal was one which, for all intents and purposes, remained constant throughout all eight years of his presidency for many observers; Clinton, at his very essence, Morrison opined, was a "single-parent household, born poor, working-class, saxophone-playing, McDonald's-and-junk-foodloving boy from Arkansas" (Morrison, 1998).

\section{April 23, 1994}

Heading into the 80th annual WHCD, Bill Clinton faced great scrutiny about his role in the so-called Whitewater scandal, in which he and his wife, Hillary, were implicated in taking part in suspicious, potentially illegal dealings relating to real estate investments they made in the 1970s and 1980s, including the charge that the thenArkansas governor Clinton used his position to pressure an individual to grant him an illegal loan. In the weeks leading up to his 1994 WHCD speech, Clinton was clearly on the defensive in response to mounting media criticism. On April 12th, Clinton made multiple remarks at the Radio and Television Correspondents' Dinner referencing the Whitewater scandal and the media emphasis on it, remarking in his opening, "You know, since this is your 50th dinner, we should acknowledge that over these last 50 years, radio and television has witnessed some of the greatest moments in American political history. And if you believe that, I've got some land in northwest Arkansas I'd like to sell you" and remarking later in his speech, "I do want to remind you of one thing. It's 3 days before April 15th, and most of you have spent a lot more time on my taxes than your own. Many happy returns" (Peters \& Woolley, 1994a). Clearly, though bothered by the media and their ceaseless coverage of the issue, Clinton was not above taking them to task head-on. 
The day before Clinton's WHCD speech, two major events made headlines whose influence on his speech would be obvious: the first, the death of former president Richard Nixon, and the second, an unprecedented press conference which was held by Hillary Clinton and was covered by both the three major over-the-air networks and $\mathrm{CNN}$ to discuss the aforementioned Whitewater controversy. Remarking on the tremendous value she placed on her privacy to justify the "confusion" in the media resulting from what she had revealed about her role in the controversial dealings, Clinton remarked, "I've always believed in a zone of privacy. And I told a friend the other day that I feel, after resisting for a long time, I've been rezoned" (Ifill, 1994).

Beginning his speech, Clinton thanks WHCA president Ken Walsh and congratulates those who won awards earlier in the evening. In light of Richard Nixon's death the day before, Clinton eschews opening with humor and instead spends time reflecting upon the passing of the 37th president of the United States and the contributions he had on society. Clinton remarks on the importance of the WHCD as a place through which squabbling politicians may draw upon commonalities by laughing at others as well as at oneself, quoting Proverbs 17:22: “A happy heart doeth good like medicine, and [sic] a broken spirit drieth the bones" (Woolley \& Peters, 1994, para. 2). Clinton continues, commenting on Nixon's death, by referencing Nixon's continued contributions to the U.S. and abroad through his acts of service which continued right up to his death. The president also makes reference to his own relationship with Nixon, explaining how he received a letter written from the former president containing an analysis of Russia and nearby countries a month to the day before his death. Clinton concludes by stressing the "common humanity" those in the audience have and suggests 
that audience members should not be quick to write anyone off based merely on the fact that they are different than themselves (para. 4).

In his opening paragraphs, Clinton works to unify and bridge the division within the audience, a useful tactic given the schisms brewing as a result of the Whitewater issue, which undoubtedly weighed heavily on the minds of the audience. Beyond the obvious attempt to spread goodwill by honoring a controversial political rival, thus appearing above petty partisan squabbles in a time of mourning, Clinton also primes the audience for a speech that would otherwise promise to be divisive given the combative political situation that has been fomenting up until this point. By beginning his speech stressing the commonalities and mutual responsibilities all attending the WHCD share, the subsequent barbs Clinton stands to lob at the press in attendance would appear to be more good-natured and less vindictive than they might otherwise have appeared had Clinton come out swinging at his detractors.

Clinton begins his self-deprecating argument by making reference immediately to support he has recently received in the form of advice and best wishes during "this very difficult time" (para. 9). Clinton proceeds to list examples of this so-called advice:

I thought I would share [the advice] with you. Here's one from my pollster, Stan Greenberg: 'I don't have a clue what people want from you.' 'Trust your instincts, but send the check anyway.' 'Take notes; save them. You can even get even with the press when you're 85,' signed Barry Goldwater. Here's one that really touched me: 'I support you 100 percent in this so-called Whitewater scandal. Furthermore, I do not believe it has even been conclusively proven that there is, in fact, a White River in Arkansas,' signed James Johnston, president, R.J. Reynolds. 'Dear Bill, 88 
can I list you as a reference?’ David Gergen. And here's one I especially prize: 'Bill, remember, it's never too late to pull out of the '92 election.' Ross Perot (para. 9).

To start, Clinton positions himself as being in a no-win situation in terms of pleasing constituents and the media by suggesting that even pollster and political strategist Stan Greenberg cannot effectively read the public. Framed thusly, Clinton defends his actions in response to the Whitewater controversy as being damned if you do, damned if you don't, an appeal which makes the media portrayal of his handling of the crisis seem unreasonable. As a consequence, Clinton gains audience sympathy from being unfairly criticized by the ubiquitous charges.

Referencing James Johnston, CEO of the R. J. Reynolds tobacco company, Clinton sardonically draws an association between himself and Johnston, someone the audience recognizes as being in possession of questionable moral integrity and someone who lacks honesty as a result of his recent involvement in court proceedings in defense of the tobacco industry. Mentioning David Gergen, Clinton's political counselor at the White House, Clinton implies that his situation is so precarious that his staff will soon be without a boss and, as a result, a job. This exaggerates the nature of the controversy, allowing the audience to reflect upon it and, consequently, recognize the absurdity of its proliferation in the media. Clinton's attempt to discredit the issue through hyperbole continues as he implies rival politician Ross Perot believes he now has a chance to retroactively win the 1992 presidential election as a result of the controversy. Once more, the potential ramifications of the issue are greatly exaggerated, presenting the issue as one which the media are clearly over blowing. 
Through the first examples of self-deprecating humor, Clinton strategically uses the style of humor much as Reagan did in his speeches. Like Reagan, Clinton is afforded the opportunity to acknowledge media criticism through ostensibly "accepting" the charges while simultaneously diminishing its efficacy as a threat to his credibility by marginalizing it through humorous hyperbole. Through the use of self-deprecating humor, Clinton, like Reagan before him, is granted a certain agency over the situation and a kind of control over the potentially character-damaging claims made by his detractors. By affiliating the controversy with the absurd, Clinton makes his stance on it plainly: the charges do not merit legitimate, sincere responses. Clinton thus leverages the superiority theory of humor through his self-deprecating "game" with the audience; the audience is thus allowed to "win" over Clinton because he initially appears weak in the face of the controversy, but his good-natured ribbing at himself - and, by association, at the controversy itself - means he does not lose any actual credibility (Gruner, 1997). On the contrary, Clinton increases his perceived goodwill for the audience by defending against the mounting criticism not with aggression or overt defensiveness, but through playful repartee.

In the following paragraph, however, Clinton takes a more aggressive swipe at the media, attesting "I am now convinced there is no deliberate conspiracy among the press corps; you just can't help yourselves. Hunting in packs is a matter of pure instinct to you" (para. 10). Here, Clinton acknowledges that while he is entirely willing to tackle the criticism through playful jest, the criticism he faces is nevertheless without merit. The previous instance of self-deprecating humor granted Clinton enough perceived goodwill to allow him to make such an other-deprecating comment; without it, a man of Clinton's 90 
stature would instead come off as a bully. Thus, self-deprecating humor is leveraged as a kind of rhetorical "padding" issued pre-emptively before an otherwise low-blow to reduce its perceived offensiveness.

In the next paragraph, Clinton is accompanied by a series of doctored magazine covers that he purports were rejected by each respective magazine because they were "too tough" on him (para. 12). These magazine covers are projected on a screen for the benefit of the audience, and as each one is shown, Clinton provides brief commentary. Clinton's response to the covers follows.

This is a cover photo of the First Couple in U.S. News. It says, '1994 Tax Tips.' Look, here's a Consumer Reports that almost made it to the newsstand; it's a picture of me and Bobby Ray Inman. It says, 'Rating the Clinton Nominations'in Consumer Reports. That's the Whitewater edition of Field and Stream with Hillary and me. Motor Trend has also applied for a White House press pass. Look at there. That's me and my Mustang. It says, 'Recall?' on it. Then, Gourmet Magazine did this cover of the White House chef. You can't see it, but it's Ronald McDonald there. One magazine almost ran this profile of my most senior advisers; that's Modern Maturity with Lloyd Cutler, Lloyd Bentsen, and Warren Christopher sitting on a bench together. Sports Illustrated came within an inch of making this the swimsuit cover. And as soon as I put my clothes back on, Runner's World smelled a scandal (para. 12).

Throughout the presentation of covers, both the Whitewater controversy and some of Clinton's more famous character foibles commonly covered by the media are referenced. The U.S. News cover Clinton references shows a black and white picture of a grim- 
looking Clinton with his hands over his face in exacerbation, contrasted with the subtitle "1994 Tax Tips"; the "Whitewater edition" of the Field and Stream issue shows Bill and Hillary's faces as two individuals rafting; the Motor Trend issue shows Clinton in a Mustang, making a car-based pun with the subtitle "RECALL?" in reference to the possibility that Clinton could face disciplinary measures for his perceived transgressions during the Whitewater controversy; the Gourmet Magazine cover shows a cartoon picture of McDonald's mascots in front of a picture of the White House, alluding to Clinton's purported love for fast-food; Sports Illustrated shows an unflattering, shirtless image of Clinton in the water wearing a snorkel; and finally, Runner's World showcases a picture of Clinton jogging with the headline "Clinton Cover-Up", a pun in reference to the previously shown Sports Illustrated issue.

All but two of the covers once more make obvious reference to the Whitewater scandal. The covers that do not allude to the scandal instead poke fun at two of Clinton's more innocuous foibles; his taste for fast-food (made popular by a famous skit on the sketch comedy show Saturday Night Live), and his less-than-swimsuit model caliber physique. By placing the two non-Whitewater related covers throughout the presentation, Clinton achieves several key rhetorical outcomes.

Secondly, the banal nature of the two other traits about which he made selfdeprecating jokes worked to undercut the severity of the Whitewater references. Although the scandal was tackled through self-deprecating humor, the fact remains that the implications of the scandal Clinton faced were nevertheless severe. Clinton's perhaps unpresidential physique and unrefined palate implied by the jokes notwithstanding, like Reagan before him, the non-Whitewater flaws Clinton tackled were largely 
inconsequential. That this is so allows Clinton to make use of self-deprecating humor's ability to humble and lower any social distance perceived between himself and his audience, without taking any actual hit to his character or credibility. Following the superiority theory of humor as it applies to self-deprecating humor, an audience that laughs at jokes which make them feel superior to the individual who uses it can be used to humble the joke maker. Faced with an audience made up of individuals critical of Clinton, Clinton chooses a number of low-hanging jokes which he would not mind the media recognizing and "presents" them. In this way, Clinton is using largely insignificant personal quirks to distract from more potentially damaging topics.

Clinton continues, showing a magazine from 1984, naming David Gergen Man of the Year, along with a contemporary cover of left-wing magazine Mother Jones bestowing upon Gergen the same designation. Gergen served as a political analyst for both Reagan in 1984 and Clinton in 1994. On the issue of negative media portrayal, Clinton continues, showing actual covers of Time magazine in which he was unfavorably portrayed; the first, a cover featuring Clinton's face in inverted shades of black and white along with the headline "Why Voters Don't Trust Clinton", and the second, featuring a small picture of Clinton underneath a large headline "The Incredible Shrinking President." Clinton responds to each cover with a similar, though obviously edited cover to compare "how much better the press has been to [him]" (para. 15). Complementing the first Time cover, Clinton shows a version in which his face is adorned with a crudely drawn mustache, glasses, an earring in his ear, and several teeth shaded out to give the impression they are missing along with the addition of the headline "We Just Don't Like This Guy." The original "Incredible Shrinking President" cover, on the other hand, has a 
changed title which reads "The Incredible Growing President" and shows Clinton as a sumo wrestler. After, Clinton jokes that the "rejected covers" are proof not of cruelty, but of "courageous restraint and collective good judgment of the Washington press corps" (para. 16).

Clinton's strategy here is a continuation of that which he has used throughout his speech. Clinton is positioning the media coverage of him as being unduly negative, unfair, and downright petty. As with the direct references made to the Whitewater controversy itself, Clinton is associating his media coverage with over-the-top, fictitious examples of cruel depictions of him to reframe his interpretations as being not fair, reasoned responses, but those which violate journalistic integrity. Time, a popular, longrunning magazine famous for its annual "Person of the Year" feature, is thus relegated to the likes of a schlocky tabloid.

As the speech progresses, Clinton suggests that as he works on image problems of his own, the media might also work to improve its own collective image. Clinton gives his own advice as he "[extends] the hand of peace" to the media.

Now, you might ask, why do I want to help you? Why do I want to help you? Message: I care. Anyway, here's my advice: Get booked on Larry King; go around the President and speak directly to the American people; pray that Columbia Journalism School will get a basketball team that will go to the Final Four. Learn to play a reed instrument; do not borrow money; do not lend money; do not make money—and for goodness sakes, do not lose money. As a matter of fact, the only safe thing is the barter system. Next advice is, never get too busy for a good haircut. And finally, in consultation with the Vice President, since all of 
you are going through the White House trash anyway, please separate glass, paper, and plastic (para. 17).

Continuing to take the media to task for how they have covered him, Clinton offers suggestions which are seemingly related to his own issues though which, upon reflection, serve to deprecate the media. Clinton's disdain for the media is evident in his explanation for why he is offering advice, as he needs to consult a slip of paper for the simple "I care" justification, driving home the contentious relationship he has with the media. When giving his "advice," Clinton again references both inoffensive personal traits known to the media (such as his "reed instrument" comment, referencing his own playing of the saxophone, and his haircut remark) as well as more Whitewater references in his comments on money and the barter system. Once more, Clinton is "sandwiching" Whitewater comments in-between less damning media critiques. The "advice" Clinton gives is also highly critical of the means through which the media obtain information about him, suggesting that they need to resort to digging through the White House trash to find scoops about him. Here, Clinton goes for the jugular; the media, Clinton suggests, not only are unfairly portraying him, but are obsessively doing so, reaching levels of tabloids.

In paragraph 18, Clinton impels the media to "be consistent" by admonishing them for a perceived lack of consistency when criticizing his wife for making money from commodity trading. Clinton takes the Wall Street Journal to task in particular, suggesting that the paper's criticism of Hillary for profiting from trading as being equivalent to "Field and Stream criticizing somebody for catching fish" (para. 18). In the next paragraph, Clinton apes Reagan in his 1984 and 1986 WHCD speeches, suggesting 
that the media should be "more positive" and that "instead of characterizing me as 'beleaguered,' characterize me as 'somber' and 'courageous' and 'Lincolnesque.' And remember, if you really want a friend in this town, get yourself a dog. I wish somebody had told me that before I showed up with a neutered cat" (para. 19). Here, Clinton suggests that the mere words the media use to describe him could change how he is seen. By suggesting that such a simple change could alter popular perception of himself, Clinton acknowledges the tremendous power the media have for shaping an individual's image and, by virtue, drives home the point that the media have a responsibility to be more fair and accurate.

Clinton continues, suggesting his tongue-in-cheek "good advice" for the media is given because of his repeated stance that "we are all in this together" (para. 20). He finishes by suggesting that the "hits" the American people have taken vastly pale in comparison to that which the media have received and says that the media have "a tough job ahead trying to restore [their] good image now" (para. 20). Now, Clinton is reversing the narrative. Once staving off attacks from the media, Clinton is no longer on the defensive, instead framing the media as being worse off than he is. Clinton's word choice here implies that the damage the media have done to themselves is significant.

Suggesting that to repair their image would be a "tough job," Clinton is driving home the extent of their loss of credibility as a result of how they have portrayed him. As a consequence, the aforementioned litany of self-directed jokes take on a new light. Because the media lack credibility, the ubiquitous negative coverage of the president likewise lacks merit.

In the next paragraph, Clinton lays out a series of steps that he himself will 
supposedly follow in order to assist the media. Such steps include, "I am going to start delivering my speeches exactly as written. That way you'll never have to sit and listen to another one. I promise never again to get mad when Andrea Mitchell or Rita Braver or Brit Hume refer to me as the 'current' President" (para. 21). Following that, Clinton promises to help the media traverse slow news days by offering "potential scandals" including "overdue library books from law school, the seeds of grapes I've eaten in supermarkets, the discrepancy between my actual weight and the weight on my driver's license, up until now the absolutely secret lab tests done on the Astroturf in my pickup. And there will be a blanket statement to go along with each one saying that I am sorry I didn't tell you that before" (para. 22). By suggesting that the media "need help" for slow news days, Clinton further discredits the media and their Whitewater emphasis by framing the issue as being perpetuated merely to fill time and attract viewer attention. Clinton's further suggestions for "scandals," inoffensive and bland as they are, work by association with Whitewater to further marginalize it as an issue which merits discussion among the media.

To conclude his 1994 WHCD, Clinton continues to go for the throat on the subject of Whitewater by referencing a recent interview he gave with MTV in which he declared that he wears briefs. Clinton "comes clean" on the "issue" in his conclusion:

I do want to take an opportunity to come clean on a statement I made earlier this week. In an appearance on MTV, I was asked a question about my undergarments, more specifically, whether I wore boxers or briefs. I answered, "I wear briefs," which is a true statement that speaks to the current facts. ...I did not show my briefs at that time out of an exaggerated and wholly inappropriate sense 97 
of my zone of personal privacy_-which I drug up here with me from Arkansas. I want you to know tonight that I regret that deeply, and like my wonderful wife, I have been rezoned (para. 23).

I must also acknowledge that for a short time during my youth, I did in fact also wear boxer shorts. It was actually a brief period of time, and this semantic coincidence may have been the source of my confused response on MTV. The number of boxer shorts totaled six pair in all: three white, two striped, one baby blue with a Razorback hog and little red hogs (para. 24).

I am taking this opportunity to make a full and complete disclosure. I have turned all my underwear over to Mr. Fiske's office-including the receipts from their donation to charity and the tax deductions I took for them in 1962: \$3.38. I'm also making copies of my underwear available to the news media. (para. 25).

In paragraph 23, Clinton makes clear reference to wife Hillary's comments made the day previous about her involvement with the Whitewater issue and her being "rezoned" (Ifill, 1994). Clinton forgoes concluding his speech with the solemn kind of closing remarks which presidents typically employ at the end of a WHCD that praise the media for their work. Instead, Clinton subverts the WHCD norms by employing self-deprecating, yet simultaneously other-deprecating, humor at the expense of the audience he might otherwise praise. Were it not already abundantly obvious throughout the previous portions of his speech, Clinton is clearly on the attack against the media, a fact patently clear to the audience in his ludicrous boxer/briefs "scandal" he sarcastically discloses. In the face of charges of corruption and impropriety, Clinton distracts from the gravity of the claims by making the issue one analogous to his disclosure of undergarment 
preference. Following the physiological benefits explicated by the relief theory of humor, Clinton releases tension about the controversy by eliciting laughter.

As he has done ad nauseum throughout the rest of his speech, Clinton closes with an elaborate comparison between a scandal he faces with an absurd, jocular comparison between an "issue" which is clearly not. Clinton employs language that had been used throughout the proceedings related to the Whitewater issue_-"current facts," "full disclosure," "confused response," and so on —with which the audience would have been familiar, making the comparison obvious. Like Reagan, Clinton highlights the absurdity of the media charges through self-deprecating humor; Clinton "accepts" the charges, over exaggerates them, and by association, makes clear how they are groundless and clearly overstated.

Distinct from Reagan, however, was the tone in which Clinton framed his argument. Where Reagan made reference to negative media portrayals of his presidency and quickly followed up with more self-oriented disparagement, Clinton often continued to be more obviously aggressive, and employed other-directed disparaging comments. When he did use self-deprecating humor, Clinton often appeared to be aping the humor style of famous stand-up self-deprecating comedian Rodney Dangerfield. Known for his heavy use of self-deprecating humor and his catchphrase "I don't get no respect!", Dangerfield made a career largely around self-deprecating humor based on the notion that those around him treat him unfairly and with disdain. Coming from a similar perspective, Clinton not only works to discredit criticism he faced, but also to garner a kind of esteem from the audience as a kind of man-against-the-world. 


\section{April 29, 2000}

Entering the 2000 WHCD during the last year of his presidency, President Clinton had not faced the same level of media criticism that he did heading into his 1994 speech. A week before his speech, Elián González, a young Cuban boy who had been smuggled into the United States in November 1999, was taken from his home by armed federal agents to be repatriated to his native Cuba on orders of attorney general Janet Reno. While this generated some media controversy, criticism Clinton faced was nowhere near that which he experienced in 1994. With the Whitewater scandal long behind him, and the Monica Lewinsky scandal of 1998-1999 likewise fading in terms of media coverage, at the time of the $2000 \mathrm{WHCD}$, media emphasis of Clinton predominantly focused on his position as a lame duck president and his work to assist vice president Al Gore as he campaigned in preparation for his own run for the presidency, which would take place later that year.

Clinton begins his 2000 WHCD thanking the WHCA president, vice president, and the audience for attending. Clinton then proceeds to show a number of pictures of himself; the first, "taken moments ago," shows a smiling Clinton, which he attests "proves without a shadow of a doubt that [he is] indeed happy to be here" (Clinton, 2000, para. 1). In the next paragraph, however, Clinton suggests that he perhaps is not happy to be at the dinner, and impels the media to speculate. Clinton continues, and shows a picture of himself and Al Gore, and suggests that while it may seem as if Gore is clapping for Clinton's "policy initiatives," he suggests that "those are not his real hands" (para. 2). Finally, Clinton shows two more pictures: the first, of Clinton with someone in an Easter Bunny costume, which he suggests is "not the real Easter Bunny," and the second, a 
doctored image of Mount Rushmore with Clinton's face replacing George Washington's, which he describes as being "grand" and "too good to be true" (para. 3).

In his introduction, Clinton is again addressing the media propensity to question the veracity of his statements and once more implies a tendency to be overly critical of him. In contrast to his 1994 speech, however, Clinton broaches the subject with greater jollity. Because Clinton lacks a large controversy like Whitewater about which he can mock, he instead pokes fun at media accuracy in general. As a president serving his eighth and final year in his tenure, the picture he shows of himself as being part of Mount Rushmore sets the tone for the rest of the speech as something of a farewell address, particularly an address in which Clinton hopes to leave with a positive legacy.

Clinton goes on, affirming his efforts at spreading goodwill by continuing to attend the WHCD in spite of the controversies that have historically surrounded him. ...there is one thing beyond dispute tonight. This is really me. I am really here. And the record on that count is clear, in good days and bad, in times of great confidence or great controversy, I have actually shown up here for 8 straight years. Looking back, that was probably a mistake. In just 8 years, I've given you enough material for 20 years (para. 3 ).

Here, Clinton is using self-deprecating humor to extol the goodwill he has-and has had - through all of his various controversies. Although the media —and, as the dinner in which he is speaking is affiliated with the media, the audience- - have been harsh on Clinton, he has still taken it all in stride and in a show of good faith and humility, has continued to attend the dinners. By pointing this out, Clinton is bolstering his image as someone who can take the kind of abuse that the media dole out. Moreover, 
Clinton's use of the words "I've given" when describing the charges the media have levied against him frame the president as taking responsibility and ownership of many of the claims. In this, Clinton is reflecting on personal failings and, by reflecting upon them, implying that he has bettered himself. As Dewberry and Fox (2012) note, under the auspices of the superiority theory of humor described by Gruner (1997), this is in keeping with the idea that the individual who is "conquered" by a joke can be the same person who does the "conquering" Finally, describing media criticism as "material" that he has given, Clinton frames the criticism as amounting to jokes, thus nullifying much of the negativity associated with them.

As he continues, Clinton references late night talk show host Jay Leno who is attending the dinner. Of Leno, Clinton says,

This is a special night for me for a lot of reasons. Jay Leno is here. Now, no matter how mean he is to me, I just love this guy — because, together, together, we give hope to gray-haired, chunky baby boomers everywhere (para. 4).

Leno, who had savaged Clinton throughout the Lewinsky scandal seemingly every night during his show, is simultaneously insulted and brought to the same level as Clinton. As Leno is a very popular comedian, Clinton finds value in illustrating the commonalities the two share. Because the two are framed as not being all that different from each other, the barbs Leno gave to Clinton lose much of their efficacy as imagedamaging criticism. This tactic is enhanced when Clinton says that he loves him "no matter how mean he is to [him]" (para. 4). By suggesting that he enjoys the man in spite of the jokes made at his expense, along with the unifying word "together" used to further tie the two together, Clinton is positioned as being morally above Leno. In essence, Leno 
is killed with kindness, and so too are his jokes rendered inert and impotent.

Clinton continues by referencing an after-party to be held by financial corporation Bloomberg. Of the party, Clinton says,

Now, the Bloomberg party is also a cast party for the stars of 'The West Wing,' who are celebrating the end of their first season. You'll have to forgive me if I'm not as excited as everyone else is at the thought of a 'West Wing' finale party. But I've got to give them credit; their first season got a lot better ratings than mine did — not to mention the reviews. The critics just hated my travel office episodeand that David Gergen cameo fell completely flat (para. 6).

Clinton blends the line between Hollywood and his own administration in making reference to The West Wing, a show based around a fictional president and the controversies he and his administration face. Here, Clinton is again referencing the media criticism he has faced, particularly during his first term. The "ratings" and "reviews" he mentions clearly parallel that which the media said about him, allowing him to both selfdeprecate and lob at joke at the expense of the media.

Clinton proceeds to spend some time making jokes at the expense of John McCain, George W. Bush, and the Republican Party in general. Clinton makes note of the discord in the GOP, and suggests that their party is in trouble. Clinton elaborates, saying,

You know, the clock is running down on the Republicans in Congress, too. I feel for them. I do. They've only got 7 more months to investigate me. That's a lot of pressure. So little time, so many unanswered questions. For example, over the last few months I've lost 10 pounds. Where did they go? Why haven't I produced 103 
them to the Independent Counsel? How did some of them manage to wind up on Tim Russert? (para. 10).

Once more, just as he had done during his 1994 WHCD speech, Clinton is referring to innocuous, ridiculous "scandals" which he suggests Republicans tackle next. Just as in his 1994 speech, Clinton is using such absurd examples of scandals to diminish the legitimacy of the scandals already spread among the media. Unique to this joke, however, is Clinton's decision to reference Republicans specifically as being the instigators for the controversy he has received. Previously, only the media were chastised, ignoring political affiliation. That this is done during an election year is not a coincidence. Clinton needs the media on his side for the purposes of Gore's election bid in November of the year, and thus, he needs to unify the media, framing the negative spreaders of criticism as being a partisan minority, and not the media in general. This is a far cry from Clinton's 1994 reference to the media as being "unable to help" "hunting in packs" like wolves (Woolley \& Peters, 1994b, para. 10).

Clinton then proceeds to discuss his recent attempts to update his résumé. He explains that he would like to continue to be president, but because he cannot, he would "consider an executive position in another country" (para. 11). Clinton attests that his staff have given him tips on his résumé, as "they really seem to be up on this stuff" (para. 11). Continuing, Clinton lists a number of completed objectives he would put on his resume, including,

...things like 'commanded U.S. Armed Forces'; 'ordered airstrikes'; ‘served three terms as President'—everybody embellishes a little—-'designed, built, and painted bridge to 21st century'; 'supervised Vice President's invention of the Internet'; 104 
'generated, attracted, heightened, and maintained controversy' (para. 12).

Once again, Clinton acknowledges the controversy he has faced from the perspective of someone admitting to being responsible for much of that which he received. In this way, Clinton comes off as more conciliatory and less aggressive at his detractors than he would have been had he instead placed the blame at the media, choosing instead to "own" at least some of the responsibility for the criticism he has had levied at him. Clinton then "apologizes" because he has recently not "done a very good job at creating controversy" (para. 13). He says that as a result the media have "so much less to report" and suggests that that may be why they are "covering and commenting on [his] mood, [his] quiet, contemplative moments, [his] feelings during these final months in office" (para. 13). Here, Clinton is distancing himself from the past. Acknowledging that he was to blame at least in some capacity for the controversy he once faced and that he is no longer stirring up the same drama, Clinton appears as a different, better person. In the words of Dewberry and Fox (2012), "One can conquer (i.e., self-deprecate) the person they were in the past, another role they hold, or certain personality characteristics" which the scholars suggest can allow for feelings of superiority over who they were in the past (p. 9).

Clinton then proceeds to show the audience a video made which captures the ennui of a president in his last few months in the White House. Throughout the early duration of the video, Clinton is portrayed as being lonely, bored, and largely sad, though in a nevertheless humorous way. He is shown giving a speech, revealing that only famous White House correspondent Helen Thomas is in the audience, compelling her to ask "are you still here?" As Clinton roams the empty halls of the White House looking for other people, the Frank Sinatra song "One for My Baby (and One More for the Road)" plays, 105 
whose lyrics include "we're drinking my friend to the end of a brief episode...I'm feeling so bad, can't you make the music easy and sad." Throughout the clip, others remark to the camera about how they "feel bad [sic] for him;" Al Gore, Hillary Clinton, and others comment about how he has a handle on things as we see Clinton performing menial tasks like mowing the White House lawn, washing the presidential limo, and running out to deliver Hillary her lunch in a brown paper bag.

Eventually, however, the song changes to "I Got Rhythm" by George and Ira Gershwin, a far more upbeat song which begins to match the increasingly optimistic display on screen. Now, Clinton appears to be having fun, watching a movie with his dog, playing golf, receiving assistance using a computer in the Oval Office to bid on the auction website eBay, and playing the board game Battleship with General Henry Shelton in a room marked "White House Situation Room." The video concludes with a joyful Clinton riding a bike in the Old Executive Office Building and sharing ice cream bars he acquired from a vending machine with the young man who helped him use his computer.

The video as a whole serves as an effective summation of the carnivalesque (Bakhtin, 1984) nature of the WHCD. The video portrays Clinton in a decidedly unpresidential manner, in such a way that would otherwise not be appropriate in any other context. Clinton is thus allowed to let loose and have fun, both within the video and at the dinner itself. In this, Clinton removes any separation which may exist between him and his audience in terms of social stratification. For a time, the Commander-in-Chief of the world's most powerful military becomes an ice-cream bar eating, game playing, "big kid," a designation which would be far beneath him in any other context and would only serve to harm his credibility as a leader. Here, Clinton takes advantage of what Bakhtin 106 
describes as being the carnival's ability to facilitate "free and familiar contact" (p. 10) between those who are otherwise separated by authority, class, and so on, along with the idea that eccentric behavior like Clinton's which shows more base, human nature, is acceptable. By contrasting a mopey Clinton in the beginning of the film with an energetic, happy Clinton at the end, the president thus frames his impending end of the presidency as being optimistic.

Clinton is then handed an Oscar award which he proceeds to clutch while the WHCD audience gives him a standing ovation until the award is taken away. Clinton then begins to conclude his speech, remarking,

You like me. You really like me. Now, you know, I may complain about coming here. But a year from now I'll have to watch someone else give this speech, and I'll feel an onset of that rare affliction, unique to former Presidents: AGDD, attentiongetting [sic] deficit disorder-plus which I'll really be burned up when $\mathrm{Al}$ Gore turns out to be funnier than me (para. 15).

It is clear that, though Clinton may rib the media, he still enjoys the WHCD. Implying that Gore would be funnier than himself, Clinton takes for granted that his vice president will win the presidential election that year, continuing the theme of optimism and confidence shown in the previously showcased video. Following his joke about Gore, Clinton concludes the speech by extolling the power of humor and thanking all in attendance for showing up for the last eight years.

Clinton's final WHCD of his tenure as president was significantly more lighthearted than was his 1994 speech. Contextually, this makes sense; as stated, the controversy Clinton faced at the end of April 2000 was significantly less serious than that 107 
which he faced in April 1994. As a consequence, though Clinton still faced media negativity, the extent to which it dogged him was appreciably less severe. This is affirmed in the kind of humor Clinton employed at the expense of the media. Unlike in 1994 when Clinton made multiple overt references to the media as being a force of negativity and which lacked credibility, chastising the media as though it had lost its way, in 2000 Clinton tended to use more self-directed humor about his own role in the controversy. When speaking of scandals faced and not referencing himself, Clinton instead implicated his political rivals the Republicans as opposed to fingering the media as a whole.

Free from the ubiquitous media criticism which plagued him in '94, Clinton appears more laidback and jocular during the 2000 WHCD. By the point of his political career when he gave his 2000 WHCD, Clinton had faced multiple scandals and controversies and came out from them all relatively unscathed. Confident, experienced, and with an eye towards the future, Clinton was thus able to appear less defensive during his final WHCD than he did in 1994. As a consequence, Clinton could then make use of the superiority theory of humor to greater effect, since he was once more speaking from a position of power and experience and thereby afforded a quantity of his authority to "lose" for the benefit of the audience, granting him more goodwill in the exchange that results from the game of humor.

As was the case with Reagan's speeches, both of Clinton's speeches used selfdeprecating humor to both attack and defend against negative media portrayal. This, then, is a great benefit of self-deprecating humor as a tool with which one may make arguments. Self-deprecating humor allows one to defend, to attack, and to ingratiate both 108 
by themselves, as well as concurrently. In many instances, Clinton was able to make a single self-deprecating joke which managed to lessen an attack levied against him, in turn sending the attack back to its receiver, and appear as a more credible, magnanimous and benevolent individual as he did so.

\section{George Walker Bush (2001-2004, 2005-2008)}

Although Bill Clinton ended his presidency with generally high approval ratings (Newport, 2001), during and after the Lewinsky scandal and subsequent impeachment proceedings the American public largely rated Clinton low in terms of honesty and moral integrity (Broder \& Mortin, 1998). Consequently, owing to a belief that his association would harm Al Gore's campaign for president in the 2000 elections, Clinton was distanced from Gore's bid. As a result, George W. Bush, a deeply religious man who promised to "restore honor and dignity" to the White House (Bruni, 2000) during the 2000 Presidential Election, capitalized on Clinton's own faltering moral image to enhance his own. Some (Weiner, 2004) would later point to a combination of Clinton's scandal and Bush's perceived strength of moral character as being the deciding factor in determining Bush's eventual success in the 2000 election, with The Daily Princetonian submitting "post-election polls found that, in the wake of Clinton-era scandals, the single most significant reason people voted for Bush was for his moral character" (Arotsky, 2004).

Like Ronald Reagan, Bush was a president who worked to construct an image which complimented the politics that he preached. Framing himself as morally upright, God-fearing Texan who felt more at home on his ranch in Crawford, Texas (where he 
would often hold diplomatic meetings), Bush balanced the line between righteous defender of Republican virtues and the modest everyman who practiced "down-home diplomacy" (Associated Press, 2005). That Bush's Texas roots had an impact on his image cannot be overstated. Bush's speech was often laden with metaphor and symbolism that harkened to the American southwest, remarking once in response to a question about whether he wanted Osama bin Laden dead, declaring that he wanted "justice" and that "there's an old poster out west, that I recall, that said, 'Wanted, Dead or Alive"” (Bush, 2001b), referring to Saddam Hussein as heading an "outlaw regime" in his 2003 declaration of American hostilities against Iraq (Bush, 2003), and commenting on US military action in Afghanistan in 2002, "At the beginning of this war, I made it very clear, as clear as a fellow from Texas could make it: either you're with us or you're against us” (Bush, 2002). On Bush's “cowboy” imagery, political scientist Gary Jacobsen referred to it as being "populist, down to Earth" and was described by Western culture expert at Princeton University Lee Clark Mitchell as a concentrated effort by Bush to "[cultivate] that [image] of the mythic cowboy, strong, morally upright, independent and God-fearing - a stalwart figure standing against chaos" (Westcott, 2003).

Bush, prone to malapropisms, mispronunciations, and muddled metaphors (collectively referred to as "Bushisms" in the popular press (Bush \& Weisberg, 2001) making appearances on a number of merchandise including books, DVDs, and even applications for mobile phones), did little to assuage political detractors from questioning his policies. Nevertheless, his lack of eloquence perhaps served to only further foment Bush's down-to-Earth perceived character. Framed as a "guy you would want to have a beer with" (Real Beer Media, 2000), Bush projected the image of a more laid-back, 
proletarian president, which belied his decidedly bourgeois upbringing, which saw him attend Yale University and Harvard Business School and once possess part ownership in the Texas Rangers Major League Baseball team.

Bush's image was that of a man who was decisive and governed by something higher than empirical evidence. Contrasted to the calculating, uptight Al Gore and John Kerry who opposed him in the 2000 and 2004 presidential elections respectively, Bush appeared as a leader who was not afraid to govern with his heart, and as Bumiller (2004) describes, "[embrace] big risks." The image of Bush as Texan lawman was one that endured throughout both of his terms. To that end, Bush's concocted image represented something akin to political ouroboros, the cyclical dragon consuming its own tail to make what was once old new again, representing a perpetuation of many of the same calculated characteristics and manners of speech which Reagan employed to great effect two decades prior.

\section{April 28, 2001}

Heading into the 2001 WHCD nearing his 100th day in office, a sample which often serves as a benchmark by which to assess a president's successes and failures, George W. Bush had already become an incredibly polarizing president. Already characterized as a poor speaker and subsequently taken to task by the media for that perception, Bush spoke at the 2001 Radio and Television Correspondents' Association dinner in March using a great many jokes at his own expense on the subject, concluding his speech, "I don't think it's healthy to take yourself too seriously. But what I do take seriously is my responsibility as president to all the American people. It's the office I hold. And that is what I came tonight to tell you. Thank you for inviting me, and thank 
you for your horspitality [sic]" (Bruni, 2001).

Blocking an initiative ordered by the Clinton administration to reduce the level of arsenic in drinking water in March of the year, Bush had begun to draw the ire of environmentalists. Moreover, Bush's foreign policy remained a contentious issue. On April 1, a U.S. spy plane crashed into a Chinese interceptor jet, forcing it to the ground and resulting in the death of a Chinese pilot and, in response from the Chinese, the detainment and interrogation of 24 U.S. crewmembers for 11 days (BBC, 2001). On April 25, Bush remarked that the U.S. would do "whatever it took to help Taiwan defend herself" in the event of a Chinese invasion, drawing anger from Chinese officials and criticism from both U.S. and foreign press alike (Wallace, 2001). In describing Bush's foreign policy, one commentator suggested it was working only to "strike a combination of alarm and antipathy into just about everybody who matters" (Baker, 2001). Bush, described as running an administration that was "driven by ideology" (Lafferty, 2001), thus entered his first WHCD on the heels of a number of recent incidents that threatened to damage his reputation in what has long been seen as a crucial time in a president's career.

Beginning his presentation, Bush explains that he will be doing "something different" by showing the audience pictures his mother, Barbara Bush, has taken of himself and his family through the years (Bush, 2001a, para. 1). Bush introduces his first picture explaining that he grew up "at a time in Texas history when it was still a rough and tumble frontier" (para. 2). The picture which accompanies this preface shows a young Bush "riding" a rabbit statue like a cowboy who rides a horse, undercutting the supposed "rough and tumble" nature of his early home life. Bush continues, showing a 
picture of himself as a child on a horse whose name, he attests, was Dick Cheney (para. 2). Proclaiming that "times were hard back then," Bush shows a picture of his father, brothers Jeb, Marvin, and Neil, and sister Dorothy, "Doro," Bush, all in a bathtub together. Bush then explains, "with all those kids in the tub, it's not arsenic in the water I'd be worried about" (para. 3). Bush then proclaims that he "always preferred a private bath" and shows a picture of himself as a young child bathing outdoors in a steel drum (para. 3).

Here, Bush does with the arsenic issue what his predecessors Ronald Reagan and Bill Clinton did before him when referencing issues they faced at the time of their respective speeches; Bush accedes that the issue is a salient one by confronting it, thereby appearing confident and able to persevere in the face of the controversy, yet because he correlates the issue with his amiable, self-deprecating joke, he distracts from any potential negative effect on his character it might otherwise have. Moreover, because the issue is compared to an absurd tangent, its potential impact on his presidency is lessened. Self-deprecating humor, then, is employed to act as a rhetorical sleight-of-hand, which distracts and diminishes the severity of an issue. Further, Bush allows the audience to feel superior to both his family and himself by showing the embarrassing family photos, which positions him as being more modest and humble in the face of criticism. "Brought down a peg" by his self-directed joke, the pictures Bush has thus far shown work to ingratiate himself with his audience by making him appear as being no different than anyone else in the audience, shameful family pictures and all.

Bush then moves on to a picture of his report card from when he attended Sam Houston Elementary School. Touching on media criticism that he lacks intelligence, 113 
Bush impels the audience to "...notice the final grades on the right: Writing, A; Reading, A; Spelling, A; Arithmetic, A; Music, A; Art, A. So my advice is, don't peak too early" (para. 3). Recognizing that slights against his intellect are ubiquitous throughout the media, Bush effectively beats the media at their own game, using self-deprecating humor to preemptively outdo any further charges made at his own expense on the subject. Like Clinton's recognition of his responsibility for media coverage of his scandals in his 2001 WHCD speech, Bush is humbled as he essentially accepts the indictments against his intelligence as being legitimate. Once more, however, Bush only acquiesces to the charges in what amounts to a mischievous, carnivalesque (Bakhtin, 1984) context in which it is understood that what he is saying should not necessarily be taken at its full face value. At the carnival, norms are subverted, and those on the top are permitted to debase themselves for its duration without negatively affecting their character as an authority. By its nature as an ephemeral event, a carnivalesque situation dictates that such unorthodox and potentially eccentric acts carried out within it are not to be held against those who carry them out upon the carnival's conclusion, irrespective of their social position. Thus, Bush uses self-deprecating humor to increase his perceived goodwill by using jokes at his own expense, while being free of the potential hits to his credibility he would take had he made the same comments in a more serious, "official" setting.

Attacking the perception that he lacks adequate policies on the environment and sustainable energy, Bush shows a picture of himself as a child standing in from of an oil derrick, which he refers to as his "fifth-grade science project" that he attests he "[built] himself. And it's still meeting our energy needs" (para. 4). Divorced from the expectations which would normally constrain him from responding to negative judgments 
with dismissive humor, Bush is allowed to respond to criticism from detractors of what would otherwise be legitimate, credibility-damaging charges with levity and absurd comparisons. As witnessed in the WHCD speeches given by Reagan and Clinton, with self-deprecating humor, a rhetor is afforded the opportunity to respond to damning indictments through appeals to the absurd while managing to maintain a perception of joviality. Because the jokes come ostensibly at the orator's own expense, a speaker who uses self-deprecating humor concurrently spreads goodwill while also marginalizing the critiques by making it understood that they are not worth responding to in a serious manner. As a consequence, rhetorically, self-deprecation works to bolster a rhetor's image while also serving as an argument that, because it is made when making fun of one's own self, is almost imperceptible in its nature as an other-directed attack. Thus, self-deprecating humor can be used to levy an attack against others or their ideas without appearing overtly aggressive or mean-spirited, thereby maintaining a sense of perceived magnanimity.

Bush continues to make light about his perceived poor education, remarking that he, “...went on to college and graduate school, but somehow, the press has gotten the wrong idea, that I was a smart aleck party guy. This is an unfair perception. See, in college, I actually did a lot of reading” (para. 4). Accompanying this comment, Bush shows a picture of him as a college student reading from a magazine featuring a scantilyclad woman on its cover. Once more, Bush takes an accusation common in the media, and responds with good-natured ribbing at his own expense. Bush goes on to remark how he joined the Texas Air Force, and how he "committed the State of Texas to defend Taiwan from attack", (para. 5) referencing his recent comments about how the U.S. 
would defend Taiwan should China attack the country. With this self-ribbing joke, Bush works to relieve tension about the issue which was still at the forefront of the media coverage by again associating it with the ludicrous, dampening the gravity of the situation. Bush concludes the joke with a hint of solemnity, thanking the crewmembers in the audience who had recently returned from China following the incident on April 1.

Bush responds to criticism about his China policy, commenting, "Some people wondered — and I'm sure there might have been a few out here—-how I would handle the recent incident in China. Truth is, I have long been a serious student of the Orient" (para. 6). Bush shows another picture as he says this, showing him as a young man smiling in front of a statue of a ghoulish demon at a Chinese temple. Here, Bush juxtaposes his purported position as a "serious student of the Orient" with the amusing picture to make light of his own perceived inexperience with foreign relations. This further suggests the unique, carnivalesque (Badarneh, 2011) nature of the WHCD. Using humor to poke fun at a recent crisis which was considered serious and potentially volatile—one that involved the death of a member of a foreign nation's military, no less-Bush illustrates how the unique rhetorical situation of the WHCD allows for far greater latitude in terms of determining that which can be a topic of humor. Because the carnival lacks the conventional social constraints found elsewhere, Bush is afforded the opportunity to broach contentious subjects in a manner he would not be able to otherwise.

Bush continues, poking fun at his father, former president and U.S. liaison to China, showing unflattering pictures of him as a younger man in the 1950s. He then proceeds to show a number of pictures of his mother, remarking that she "became a bit stressed" raising her sons and commenting on how she wrote a book with a "damn, 
mangy, ill-tempered dog...[she] treated the dog better than she treated me. She never helped me write my book" (para. 8). Bush then makes a joke at the expense of his brother, Jeb, by showing a picture of him as a child, nude. Bush concludes with a "seriouser [sic] point", referencing his wife, Laura, and the value of family, which he suggests is more important than even his position as president.

The pictures showcased throughout the his 2001 WHCD speech painted Bush in a more humble, modest light, keeping with his active effort to portray himself as a downto-earth and populist individual to combat the perception that he, his father, and the Bush family in general were out-of-touch with the average American. The pictures, along with the self-deprecating commentary Bush gave describing them, framed Bush as a regular family man. Concluding his speech by saying that "The defining moments in the Bush family" were not when he had achieved his presidency, but rather were "family moments," Bush worked both to lessen the popular perception that he was an elitist and to lower the social distance between himself and his audience created by his family's wealth and power by stressing the relationship with his "family full of love" as being the most important things to him (para. 11).

In his 2001 WHCD speech, Bush makes full use of absurd contradictions between what he says and what his pictures show to both incite humor and to ingratiate himself. Using Gruner's (1997) game theory of humor, Bush is juxtaposing his perceived past transgressions with his contemporary humility to showcase how he has improved upon his flaws. Thus, in his speech Bush used self-deprecating humor to not only allow his audience to feel superior to himself, but also for him to feel superior to himself. Framed this way, Bush had shown that he, in effect, "conquered" the "old him," and emerges a 
new, better person.

\section{April 29, 2006}

Facing a stagnant economy, rapidly increasing gas prices, continued media scrutiny over government handling of Hurricane Katrina, polling data which attested that seven out of ten Americans believed that the country was headed in the wrong direction (Roemer, 2006) and embroiled in two increasingly unpopular wars in Iraq and Afghanistan, George W. Bush faced perhaps more ubiquitous criticism heading into his 2006 WHCD than either Reagan or Clinton had during the time of any of their WHCDs previously analyzed. Consequently, Bush, already in his second term as president, entered his 2006 WHCD in a decidedly precarious situation. Beyond working to improve his own image and that of his administration, Bush was also tasked with improving the image of the Republican Party for the benefit of his allies facing midterm elections in November.

The uniqueness of Bush's situation was exemplified immediately at the beginning of his 2006 WHCD speech. Standing next to Bush at an adjacent podium is impersonator Steve Bridges, wearing the same outfit as Bush and mirroring his gestures and handmovements. Bush and Bridges begin, with Bush warmly and articulately welcoming the audience to the dinner, and Bridges bluntly interjecting, "here I am" (Sheffield, 2006). The two continue their introductory repartee,

Bridges: Here I am at another one of these dang press dinners. Could be home asleep, little Barney curled up at my feet. But no, I've got to pretend I like being here. The media really ticks me off. The way they try to embarrass me by not editing what I say. Well, let's get things going, or I'll never get to bed. 
Bush: Thank you, Mark. I'm absolutely delighted to be here (Sheffield, 2006).

In Bush's introduction, the unique rhetorical comedic "double act" strategy he employs is established. Bush speaks as is expected of a president and approaches the audience in a more serious, solemn manner, serving as something resembling a comedic "straight man" common in farcical and sketch comedy, while Bridges acts as the humorous "stooge," representing Bush's well-known foibles in a hyperbolic, satirical manner. Bridge's introduction critiques the media as being unfair to "him" just as all of the previous WHCD analyzed did to the respective speakers to various extents, but unique to this situation, because it is not really Bush speaking, the indictments are even more jovial than the previous instances. Consequently, because Bridges conveys "Bush's" disdain for the media in such an over-the-top fashion, it is understood that Bush's true feelings are not nearly as critical. In the introduction, the audience is made to recognize that Bridges is the jester to Bush's king, positioning Bush as magnanimous and able to take a joke, increasing his goodwill to the critical audience.

Bush continues, stressing how much he enjoys the dinners, while Bridges adds "It's just a bunch of media types. Hollywood liberals, Democrats like Joe Biden. How come I can't have dinner with the $36 \%$ of the people who like me?" (Sheffield, 2006). Bridges adds, "There's got to be a friendly face out there somewhere. There's Justice Scalia. There's Justice Alito. Hey, boys. Bet it feels good to be out from under those robes. Toga! Toga! Toga!" In response, Bush provides a more placid, laconic recognition, "You know, it's good to see so many influential guests here tonight, Justice Scalia, Justice Alito" (Sheffield, 2006).

Once more, Bush plays off of Bridges as the impersonator embellishes his 119 
perceived ineloquence and unprofessional demeanor. Serving as a caricature of the media perception of Bush, Bridges is employed to both affirm Bush's goodwill for the audience by establishing himself as someone not above being mocked, while concurrently framing the media criticism as itself being over-exaggerated. Like his 2001 WHCD speech in which he employed old pictures to self-deprecate and subsequently establish himself as being "beyond" how he used to be, Bush is using Bridges to affirm that he is, in fact, not that bad. Because Bridges functions as a character representative of Bush's popular perception in the media, he functions rhetorically to critique the same perception as itself being overwrought. In this, Bridges serves as a "stand-in" for how Bush sees how he is portrayed in the media which allows him to take the media to task for it, while concurrently bolstering his image as a down-to-earth, gregarious figure of authority because he does so in a self-deprecating manner.

The two continue, noting Dick Cheney's absence in the audience by making reference to his recent hunting accident in which he shot Texas attorney Harry Whittington (The Smoking Gun, 2006). As they do so, both make jokes at Cheney's expense, with Bush ribbing, "Dick's a good man. He has a good heart-- well, he's a good man.” Bush continues, remarking, "Ladies and gentlemen, I'm feeling chipper tonight. I survived the White House shakeup. So I want to talk about some serious issues, such as -" only to be cut off by Bridges, who interjects, "Ok. Here it comes. Nuclear proliferation. Nuclear proliferation. Nuclear proliferation," to which Bush in turn responds, "Nukear pro liberation [sic]". Bridges continues, "All right, all right, maintain. Be cool. Let's give this a try. We must enhance noncompliance protocols. Sanction not only IAEA formal sessions, but through intercessional contact" and Bush replies in kind, "We must enhance 120 
noncompliance protocols, sanction not only at EIEIO formal sessions. But through intersexual conduct" (Sheffield, 2006). Bush's comment about the "White House shakeup" refers to recent changes to the White House staff. Ignoring the topic, however, Bridges and Bush continue on the tangent of Bush's perceived lack of eloquence. Here, the tables are turned, with Bridges taking the role of the more articulate speaker, and Bush appearing to accept the media portrayal of his poor public speaking skills. Distracting from a salient issue, Bush draws attention to his poor speaking abilities, abilities which are far less egregious and damaging to his credibility. Thus, as was the case in Bush's 2001 WHCD speech, self-deprecating humor is once again used to obscure a topic receiving significant media attention.

Bush and Bridges continue, both making multiple malapropisms, including Bush's unifying, patriotic rejoinders,

My friends, our purple mountains with ramparts red glare, white with foam and justice for all, fruity plains, gallantly streaming, from sea to shining sea, with a shining city on a shining hill, above a shining prairie and maybe some shiny trees and a few shrubs, I see a shiny America. I love America. Because it's full of Americans. I believe we in America should come together, Republican and Democrat and John McCain. I believe in bipartisan bipartisanship. (Sheffield, 2006).

Concluding his "bit," Bush identifies the "ruggedly good-looking guy" as Bridges, who Bush claims did "[all his] debates" against Senator John Kerry for him, along with his news conferences. Bush ends his speech thanking all in attendance for giving "us" a chance to laugh, a unifying word which positions him as being one with the audience. 
Beyond the novel approach Bush took in his 2006 WHCD in using a "double" through which to deliver self-deprecating jokes, his speech was also unique in that he largely eschewed referencing specific controversies he and his administration had been facing. Although making an oblique reference through Bridges about the perception abroad that he is arrogant, and briefly commenting on the Dick Cheney hunting trip incident and the White House "shakeup," Bush neglected to tackle any of the litany of issues which plagued his administration at the time of his speech. Given the severity of many of those issues, it can be said that self-deprecating jokes made in reference to them would not have been appropriate, even in the rhetorically unique situation of the carnival which is the WHCD.

In the absence of direct references to scandals and controversies, Bush instead joked about a general negative media perception of him and of common personal quirks widely perpetuated. Gruner (1997) suggests under the framework of humor superiority theory that a "bit" such as the one Bush used would be an example of "one part of a man laughing at another part of himself" (p. 152). Quoting Morreall (1989), Gruner (1997) posits that the kind of self-deprecating jokes Bush made through Bridges would have represented "relatively harmless bungle[s]" (p. 152). In the face of the great deal of public scrutiny he was up against heading into his 2006 WHCD, Bush leveraged selfdeprecating humor in a way that the audience could feel superior to him, but not at the expense of losing something he cares about losing. In other words, that which is mocked about Bush is superficial and largely innocuous.

I have previously used the analogy that using self-deprecating humor for a strategic rhetorical purpose is the rhetorical equivalent of "taking a dive" in a game. 
Using Gruner's (1997) thesis on humor as a game, we may begin to see that analogy take form; because Bush is already perceived as someone who lacks credibility as a speaker, further driving that point home could not possibly harm him any further. When an individual takes a dive in a game, it can be assumed that it is done to receive something of greater value than that which is lost as a result of losing, or as a result of the dive itself. Thus, in 2006, Bush recognized a situation in which his general character could be enhanced through over-embellishing what amounted to be mere quirks - mannerisms, mispronunciations, and so on—while avoiding specific references to scandals as Reagan or Clinton did which could have only further damaged his reputation.

In both his 2001 and 2006 WHCDs, we find instances of Bush's use of selfdeprecating humor as functioning both to be proactive and reactive. As a proactive rhetorical strategy, Bush employed self-deprecating humor to dilute the damage on his character that could be done through credibility-harming chiding about his ineloquence. By making jokes at his own expense about his poor oratorical acumen, Bush positions himself as being well aware of the insinuations, and moreover, able to make light of them better than anyone else could, lessening the power of jokes coming from other sources. As he uses such self-directed jokes, he also positions them as being no big deal.

As a reactive strategy, Bush uses self-deprecating humor to respond to media criticism as a method which deflects attention elsewhere, making salient the aforementioned inoffensive character quirks in the place of significantly more rhetorically dangerous scandals and controversies. Because the jokes he makes are at his own expense, we as an audience are more inclined to believe that he is expressing goodwill for us - after all, those in a position such as Bush's must be quite confident and 
comfortable if they are willing to make fun of themselves, and moreover, such jokes stress humility for the benefit of the audience — and as a consequence, we may perceive the germane transgressions as being either less offensive, or that Bush's role in them may have been less prominent by virtue of his strong, established character.

Finally, Bush's use of self-deprecating humor illustrates the superiority theory of humor as a means of appearing better at one's own expense, either through comparison to how one used to be, or by way of comparing how one is seen relative to how one really is. Both the childhood pictures shown during his 2001 speech and his "double" during the 2006 speech show the respective contemporary Bush as being better than how he is portrayed, especially by the media. In 2001, Bush is able to point to the past to distinguish how he is at the time of his speech to highlight how he has grown as a person. In 2006, on the other hand, Bush uses the impersonator Bridges to showcase his character traits as being exaggerated to the nth degree. In comparison, then, Bush appears significantly more competent and on-the-ball. That Bush agrees to "play along" and himself use malapropisms and mispronunciations only serves to further cement his goodwill as a humble person.

\section{Barack Hussein Obama (2009-2012, 2013)}

Just as the image that George Bush fostered was a reappropriation of that used by Ronald Reagan, Barack Obama likewise owed much of his own image to that of protégé Bill Clinton. Like Clinton before him, Obama framed his 2008 election campaign around the concept of American renewal with a heavy emphasis on attracting the youth vote. The Obama campaign stressed empowerment and progress for all with the promise of "Change we can believe in" and a unifying rallying cry "Yes We Can!" Attesting "we are 
better than these last eight years" (Obama, 2008), Obama sought to inspire Americans to tap into the values upon which America was founded and which likewise, as the quote implies, had eroded during the Bush presidency. This tactic of stressing the value of selfefficacy in individuals was one that Obama used to great success.

Obama's image of a unifier preceded his run for president. During the 2004 Democratic National Convention, Obama's presentation as a U.S. Senate hopeful stressed the common places in which all Americans can meet: "There's not a liberal America or a conservative America - there's the United States of America. There's not a black America and Latino America and Asian America —-there's the United States of America...We are one people..." (Mendell, 2007, p. 3 emphasis in the original). Obama's image, perhaps, afforded him greater recognition as an agent of unity than most; born to a Kenyan father and an American mother, Obama captured diversity hitherto not found in candidates from previous elections.

Cool, confident, and prepared, Obama secured an image of a suave and charismatic speaker much like Clinton a decade earlier. Gen. Merrill McPeak, former Air Force chief of staff, described Obama as "no shock Barack kind of guy, no drama Obama" (Associated Press, 2008), which captured in nine words what had been a growing perception of Obama as a man who managed to be both calculating yet effortless as he made his way throughout his campaign. In short, Obama possessed great political acumen, yet his skill as an orator and his relatively humble background kept him grounded as a man of the people. With that, Obama represented the gift of rhetoric which made Reagan successful, the progressive stance and youth which benefited Clinton, and the nice-guy approachability that afforded Bush two terms as president. 


\section{April 30, 2011}

In the days leading up to his third WHCD of his first term as president, Barack Obama faced a marked dearth of criticism relative to that witnessed leading up to George W. Bush's 2006 speech. On April 27, three days before his speech, the White House released Obama's birth certificate in an attempt to quell the so-called "birther movement," a contingent of individuals who founded a conspiracy which purported that the president was not born in the United States. Although those who professed to belong to the movement were small in number, proponents of the stance were nevertheless vocal, the most famous of whom was real-estate mogul Donald Trump.

Proceeding Obama's speech, a short video is shown to the audience. "Real American," a song by singer Rick Derringer famous for being WWF wrestler Hulk Hogan's entrance music in the 1980s, plays while an image of Obama's birth certificate is shown over an American flag backdrop, "pulsing" to the music. Other patriotic images are shown, which include: a bald eagle in flight, Mt. Rushmore, two cowboys, a submarine breaching the surface, an Uncle Sam "I Want You" poster, clips from the 1980s cartoon Transformers, a clip of Hulk Hogan ripping his shirt off, a scene from the movie Rocky and Karate Kid, a clip of New York Yankees baseball players running onto a field in celebration, and a clip of basketball superstar Michael Jordan performing a back-handed slam dunk. Throughout the video, Obama's birth certificate is shown three times, with the final shot of the montage being the certificate.

Obama begins his speech:

My fellow Americans. Mahalo! It is wonderful to be here at the White House Correspondents' Dinner. What a week. As some of you heard, the state of Hawaii 126 
released my official long-form birth certificate.

Hopefully this puts all doubts to rest. But just in case there are any lingering questions, tonight I'm prepared to go a step further. Tonight, for the first time, I am releasing my official birth video.

Now, I warn you -no one has seen this footage in 50 years, not even me. But let's take a look (Schulman, 2011, paras. 2-4, emphasis added).

Beginning his speech, Obama emphasizes the "fellow" in "My fellow Americans." His use of the word "Mahalo!"-- a Hawaiian expression of gratitude-- is a clear reference to his home state of Hawaii, driving home his nature as a natural-born American citizen. The "official birth video" Obama shows is an excerpt from the opening scene of the 1994 Disney movie Lion King with "04 Aug, 1961 pm 7:24," the date of his birth, superimposed, giving the impression it was recorded off of a camcorder, and shows the titular king being raised to the sky following his recent birth. The clip, which is set in an African savanna, makes obvious reference to the charge that Obama was born in Kenya.

Following the clip being shown, Obama asserts to audience members from Fox News that the clip was merely a joke and that it is, in fact, a children's cartoon. While ostensibly making a joke about himself, the other-directed deprecation of an argument used against Obama is clear. Like his predecessors, Obama is using humor to make comparisons between an argument levied against him with an absurd example in order to discredit the argument's validity and, as a consequence, the argument's efficacy to threaten his ethos.

Obama then proceeds to thank the members of the audience for coming, including 127 
comedian Seth Meyers, saying, "I am very much looking forward to hearing Seth Meyers tonight. He's a young, fresh face who can do no wrong in the eyes of his fans. Seth, enjoy it while it lasts" (para. 8). Obama's reference to being a "young, fresh face who can do no wrong" closely resembles the media perception of him that endured throughout his campaign into the early stages of his presidency. Framing his campaign on youth, exuberance, and renewal, Obama had begun to face controversy for not living up to his lofty campaign promises. Divorced from his landmark election victory by almost three years, Obama is now working to reinvent his image. Implying that the perception that he can "do no wrong" is a fleeting one by stressing that Meyers should "enjoy it while it lasts," Obama frames his relative fall from grace in the eyes of the media as being an inevitable thing, thus removing much of his responsibility for his increasing negative coverage. Like Clinton in 2000, Obama associates himself with the comedian of the evening by drawing similarities between the two, a useful tactic given the popularity of the respective comedians.

Obama continues, Yes, I think it is fair to say that when it comes to my presidency, the honeymoon is over. For example, some people now suggest that I'm too professorial. And I'd like to address that head-on, by assigning all of you some reading that will help you draw your own conclusions. Others say that I'm arrogant. But I've found a really great self-help tool for this: my poll numbers (para. 9).

As has been the case with much of the self-deprecating thus far analyzed in previous WHCD speeches, here Obama is openly recognizing claims against him, and ostensibly acknowledging them. Yet because Obama acknowledges the charges through the use of 
humorous discourse, it is understood that he does not sincerely believe that they are legitimate grievances. In his second self-directed jab in section of the speech, Obama recognizes his lagging poll numbers, effectively informing the audience that he hears the concerns of the people, lessening any perceived distance between himself and the audience through good-natured modesty. As has been illustrated time and time again throughout the WHCD speeches, self-deprecating humor can function as an excellent means through which an authoritative speaker may express humility and suggest benevolent intent.

Continuing, Obama remarks on how he "let down [his] key core constituency: movie stars" (para. 10) and references actor Matt Damon's recent remarks on how he, too, was disappointed in his performance. Following the remark, Obama takes a jab at one of Damon's more recent movies. Referring to his "key core constituency" as being "movie stars" is made in reference to the large amount of support Obama received from Hollywood as he made his bid for presidency in 2008. Because such support came from the "Hollywood elite" which could serve to undermine his image as a more egalitarian, "man of the people" Obama could afford to disparage a famous actor and maintain a sense of goodwill in a way he could not were he to insult a less famous individual.

As Obama continues, he jokes about his wife Michelle's status as the paragon of health-conscientiousness by describing her involvement at a recent Easter Egg Roll as "[snatching the candy] right back out of their hands" (para. 11). Obama then indicts the GOP by joking about their recent attempt to cut funding for the National Public Radio. Paul Ryan, Michele Bachmann, Time Pawlenty, and Jon Huntsman—all Republicansare mocked as Obama suggests that it is they who might not be from the United States. 
Mitt Romney is likewise taken to task for his opposition to Obama's initiative for universal healthcare by pointing out that he himself passed his own universal health care act as governor of Massachusetts.

Obama then moves on to vocal opponent and public advocate of the aforementioned "birther" movement, Donald Trump. Obama proceeds to mock Trump, suggesting that he should "get back to focusing on issues that matter" like whether or not NASA faked the moon landing, or what really happened at Roswell (para. 18). Obama continues, questioning Trump's credibility, mocking him for his role as boss on the reality television series Celebrity Apprentice (para. 19). Finally, Obama shows a picture of a doctored White House which he suggests Trump would create were he in charge, a gaudy "Trump White House Resort and Casino" (para. 20).

Once the conversation moves on from Trump, Obama shows a parody trailer of the movie The King's Speech, titled “The President's Speech.” In it, it is joked that GOPapproved budget cuts have led to the removal of Obama's teleprompter. This bit of selfdeprecation makes light of Obama's recent speaking gaffes, often attributed to an overreliance on his teleprompter (Lee, 2009). Just as Bush worked to lessen the effect of media coverage of his own speech issues through the use of self-deprecating humor, this self-deprecating jab is used to end the teleprompter conversation once and for all by diluting its efficacy as an insult. By applying the same insults to himself that others have lobbed at him, Obama shows a good-natured recognition of the chiding, while also reducing its effect on his credibility.

Obama closes his 2006 WHCD by recognizing the "courage and valor" (para. 23) of the members of the armed forces, as well as of the struggles southern states affected by 130 
the severe storms the week previous are facing. Obama commends the media for their work in assisting those in need by spreading the word of their plight, both domestically and abroad. The media, Obama remarks, "defend our freedoms and allow democracy to flourish" (para. 28). Here, Obama "makes peace" with the media. Having already made reference to his initial favorable portrayal in the media in contrast to how he is now covered, Obama attempts to once more ingratiate himself with the media and restore his "do no wrong" image.

Like Bush in 2006, much of Obama’s self-deprecating humor during his 2011 speech was employed at the expense of his more or less "bland" issues - in this case, his lower poll results and his relative fall from grace in the media. Although the particular targets of self-deprecation were more or less the same between the two presidents, the contexts in which they were given were entirely inimical. Bush, facing a great deal of controversy, erred on the side of self-deprecating about inoffensive personal traits to obfuscate and distract from more egregious infractions. Obama, on the other hand, had relatively fewer things about which to self-deprecate. In comparison to Bush, Obama's relatively lower poll numbers and general increase in media negativity about him were significantly minor in comparison to the litany of national issues with which Bush dealt. As a consequence, while Bush's self-deprecation in 2006 was employed to defend against a host of criticism and to save face for the Republican Party as a whole, Obama's selfdeprecation was utilized as a more general strategy of image bolstering.

Obama's 2006 WHCD serves as an useful speech by which to distinguish between when it is appropriate to employ self-deprecation compared to when otherdeprecation functions better as a rhetorical strategy. In his speech, Obama sparingly 131 
employed self-deprecation. On the contrary, much of his presentation focused on political rivals, principally Donald Trump, and as a consequence, generally Obama employed the superiority theory of humor to frame himself as superior to them. Moreover, that those he insulted were all in positions of power and had already lobbed their own insults at Obama made them "fair game" as targets for disparagement. A rhetor that employs humor to make a statement must be cognizant of when and how to deploy certain styles of humor. Recognizing when to insult oneself and when to target others is imperative if one is to ensure that a perception of goodwill is maintained and that one does not appear as a bully, an always-present threat when in a position of power relative to an audience.

Finally, Obama's theme of using self-deprecating humor to refer to a perceived backslide from earlier success makes those same successes more salient to the media. By referring to his "honeymoon period" (para. 9), Obama brings to mind his early successes and his subsequent positive media coverage. While framed as self-deprecation, by acknowledging them Obama is nevertheless making the argument that he was once favored by the media and through his attempt to ingratiate himself with them, should once more be positively covered.

\section{April 27, 2013}

Fresh off a victory ensuring his second term as president, Obama approached the 2013 WHCD with renewed vigor and confidence. Nevertheless, as was the case with the previous seven WHCDs analyzed, Obama still faced a number of issues that undoubtedly had an impact on the speech he would give.

On March 1, a budget sequester that was initially to have taken effect on January 1 but was delayed by the American Taxpayer Relief Act of 2013, came into effect, 
forcing massive budget cuts. The strong partisan rhetoric by both sides of the political spectrum served only to increase the already expanding divide which existed between Democrats and Republicans.

On April 15, 12 days before Obama's 2013 WHCD speech, two improvised explosive devices were detonated during the Boston Marathon, killing three and injuring 264 people. Before the perpetrators of the bombing were caught four days later, an additional police officer was killed and 16 more were wounded in the ensuing gunfight.

As Obama approached the podium to speak, the song "All I do is Win" by artist DJ Khaled is played. The song, whose lyrics include "All I do is win, win, win no matter what" and "I never been defeated, and I won't stop now," is congruent with Obama's victory in the last presidential election and serves to set the stage for what he describes in his opening statement as "changing things around here a little bit" (Obama, 2013, para. 1). Obama continues,

Actually, my advisors were a little worried about the new rap entrance music. They are a little more traditional. They suggested that I should start with some jokes at my own expense, just take myself down a peg. I was like, guys, after four and a half years, how many pegs are there left? (Obama, 2013, para. 2). For his first instance of self-deprecation, Obama makes a joke at his own expense while neglecting to reference a specific event, scandal, or characteristic about which to jest. In this way, Obama plays it safe, making neither a reference to a specific scandal as Reagan and Clinton did with Iran-Contra and Whitewater respectively, nor giving one in reference to a character quirk as Bush did in his speeches. Nevertheless, like Clinton's 
2000 WHCD speech (Clinton, 2000, para. 3), Obama does recognize a general trend of humbling at the expense of the media.

Obama then thanks those in attendance, including his wife, who, he remarks, has just been on the cover of Vogue magazine. Obama proceeds to show "his own magazine cover" (para. 4) that, also like Clinton in his 1994 WHCD presentation, portrays him in an unflattering light. On that tangent, Obama explains, "These days, I look in the mirror and I have to admit, I'm not the strapping young Muslim socialist that I used to be. Time passes. You get a little gray" (para. 5). The "Muslim socialist" remark is a reference to detractors who had long dogged Obama for being both a Muslimand a socialist, both claims he has vehemently denied throughout his tenure. Like the "birther" jokes made during his 2011 WHCD, Obama once more targets a common criticism trope that he has faced and discredits it through self-deprecating acknowledgement.

Changing topics, Obama moves on to making light of Eric Holder, the National Broadcasting Company (NBC), and the rapper Jay-Z. After lobbing jokes at the expense of CNN, MSNBC, and Fox News, Obama references his new "favorite source for political news", that "[tells] it like it is. It's called whitehouse.gov" (para. 16). Like Reagan, Clinton, and Bush, Obama uses the platform afforded him at the WHCD to address perceived media biases and undue negativity against him. As was the case with the previous presidents, because he addresses the media under the framework of selfdeprecating jabs - in this case, implying that his favorite news source is the website maintained by his own administration, making light of his perception of arrogance referenced in his 2011 WHCD - Obama does not come off as being petulant or defensive as he issues his charges at the media. Rather, through self-deprecating acknowledgement 
of his perceived arrogance illustrated by implying he prefers to read news sure to be favorable Obama appears more grounded and even keel, maintaining his character as an affable individual.

Throughout much of the remainder of the speech, Obama employs much otherdeprecating humor. He again chides the media, this time for their perceived cynicism and "feeding...suspicion and conspiracy theories" (para. 18), various Republicans like Mitch McConnell, Michele Bachmann, and Marco Rubio along with the party's role in the sequester, and George W. Bush in reference to his newly opened presidential library. Commenting on his own library, Obama then remarks that he is "also hard at work on plans for the Obama Library. And some have suggested that we put it in my birthplace, but I'd rather keep it in the United States” (para. 27). With any lingering damage the "birther" movement may have had on Obama essentially dissipated during his crushing indictment of it and famous proponent Donald Trump during the 2011 WHCD, such a joke allows Obama to remind the audience of his victory over his opponents who used the specious argument, leveraging Gruner's (1997) superiority theory to bolster his image as he did so.

Obama then references director Steven Spielberg and actor Daniel Day-Lewis, both involved in the recent film Lincoln, and points them out in the audience. Obama then shows a trailer featuring an interview with Spielberg as he remarks how, after completing Lincoln, Obama is his next subject on which to base a movie. Spielberg remarks that he "Never got his transcripts and they say he's kind of aloof," once more making a joke about the Obama birth certificate controversy. Spielberg then proceeds to describe how Daniel Day-Lewis would be the perfect actor to play Obama, and in the 135 
next scene, Obama is shown as Daniel Day-Lewis in character. Similar to the unique situation with impersonator Steve Bridges speaking with Bush during the 2006 WHCD, Obama, pretending to be Daniel Day-Lewis playing Obama, allows him to poke fun at some of his more commonly parodied character traits, grousing "You wouldn't believe how long it takes to put these ears on in the morning. I don't know how he walks around with these things." Joe Biden is likewise skewered, although Biden is played by African American actor Tracy Morgan.

Upon completion of the video, Obama concludes on a solemn note, making reference to the Boston Marathon bombing, recent flooding in the Midwest, the explosion at the West Fertilizer plant in West, Texas, and service carried out by military personnel overseas. Obama commends the members of the media who "took time to wade upstream through the torrent of digital rumors to chase down leads and verify facts and painstakingly put the pieces together to inform, and to educate, and to tell stories that demanded to be told" (para. 33).

The themes upon which Obama based his self-directed barbs remained consistent in his 2013 WHCD with those employed in 2011. Like in 2011, Obama had not faced a great deal of controversy which he could reference, as much of the issues which the nation faced at the time of each of the speeches given were not directly related to Obama himself. Lacking scandals like Iran-Contra, Whitewater and Monica Lewinsky, unpopular wars in Iraq and Afghanistan, and so on as Reagan, Clinton, and Bush faced, most of the controversy Obama did personally face did not lend itself well to self-deprecating humor. As a consequence, like Bush before him, the jokes Obama made at his own expense were once again character traits - his age, his negative portrayal in the media, his ears, the 
discredited "birther" movement, and so on—and not policy issues. Likewise, Obama once again largely took opponents to task with disparaging jokes at their expense, leaving self-deprecating humor to function more as an ancillary rhetorical tool.

\section{The Everyman President}

Different in character though they all may have been, each of the four presidents whose speeches I have analyzed share a defining trait which might speak to their decisions to use self-deprecation. Simply put, each of the four presidents, at one point or another, portrayed himself as being a "man of the people." From Reagan, depression-era Middle American turned Hollywood cowboy who personified the American spirit of rugged individualism, the affable saxophone-playing, fast-food loving, salt-of-the-earth, Arkansan Clinton, the baseball-loving, "man you would like to have a beer with" rancher Bush, or the Horatio Alger up-by-the-bootstraps charismatic unifier Obama, each coveted an image which framed himself as being on the audience's level. Self-deprecating humor's ability to humble oneself is unquestionably a trait which can serve an authority figure well, allowing one to construct an image which paints them as the consummate everyman. In short, self-deprecating humor allows one to tear down the stratifying walls built by authority and mark its user as "one of us."

Yet we are keenly aware that they are not one of us. No matter how they frame their image, presidents cannot truly fully divorce themselves from the power their status projects upon them. Irrespective of their attested humble beginnings or egalitarian ideology, the nature of the presidency of the United States connotes tremendous wealth and power. The presidency of the United States is simply an authority without compare. In spite of this, however, we might again consider Bakhtin's (1984) notion of carnival and 
the nature of the White House Correspondents Dinner as a unique event. At each WHCD, the rules of authority as we know them are suspended, and speeches given therein represent something similar to a rhetorical "Twilight Zone." This is so because the WHCD is an event which operates under many of the same tenets of the carnival-the powerful are permitted to degrade themselves, the "lower classes" are permitted to laugh at the powerful, and a general atmosphere of jollity is encouraged, distinct from the humdrum, stifling conventions of general politicking. As a consequence, speaker and audience members alike forgo conventional recognition of authority and within that unique context, we are largely able to view them as disparate from their position.

This, I suggest, is the crux of the application of self-deprecating humor in a context in which an individual in a position of authority wishes to persuade those who are not. All four of the presidents analyzed had their own quirks, ideologies, and strengths and weaknesses in character distinct from one another. Yet their unifying quality-their position as President of the United States-along with the shared setting in which they gave their remarks, marks them all as orators who, regardless of the specific political situation in which they spoke, were afforded the opportunity to use self-deprecating humor's multifaceted nature to bolster, defend, and attack. Although the intent, outcome, and frequency of the use of self-deprecating humor varied both by president and by speech analyzed, that self-deprecating was nevertheless a consistent hallmark of each of the eight WHCD dinners chosen speaks to the appropriateness of its use as a rhetorical tool. 


\section{CHAPTER V CONCLUSIONS}

Subverting wisdom suggesting that public speakers should eschew using selfdeprecating humor for fear of damaging speaker credibility (Hackman, 1988), I have identified through my analysis several situations when self-deprecating humor can perform beneficial rhetorical functions, chief among these being an increase in speaker ethos. Using Bitzer's (1992) notion of the rhetorical situation to identify each unique political context in which the respective presidents' speech was given, I have analyzed circumstances ranging from personal and political scandals, national tragedies, negative public and media perception, to public speaking gaffes. All of which, I have found, in one way or another, were targeted by means of self-deprecating humor, demonstrating the brand of humor's adaptability and all-around multifaceted nature.

I have also recognized a number of specific, helpful rhetorical outcomes which can be achieved through the use of self-disparaging humor in those situations. Whether it is employed to preemptively diminish the damage of a negative claim to speaker credibility, as done by George W. Bush to great effect in his 2006 WHCD speech (Sheffield, 2006), to defend against attacks by discrediting argument and source credibility like Bill Clinton in his 1994 speech (Woolley \& Peters, 1994a), to serve as an 
other-directed attack under the guise of self-effacement as accomplished by Barack Obama in 2011 (Schulman, 2011), or to serve as a general means by which to ingratiate oneself and extend goodwill as done by all four presidents throughout their speeches, self-deprecating humor can be appropriated to achieve many rhetorical results.

It should be noted that much of the self-deprecating used was made at the expense of relatively innocuous personal flaws. Reagan, Bush, and Obama in particular generally focused on age, poor speaking ability, and physical characteristics and general negative media perception respectively in lieu of tackling more germane, serious issues in a selfdeprecating manner. This speaks to the value of self-deprecating humor as a means of distraction-through-ingratiation. By picking on those personal flaws which did not affect their overall character, the respective presidents were humbled, yet their credibility as leaders was not threatened. Here, we can see that self-deprecation functions as a means of deflecting more serious face threats and criticism by conceding and "sacrificing" less damaging personal foibles for the benefit of an audience.

The superiority theory of humor (Ferguson \& Ford, 2008), allied with Gruner's (1997) theory of humor as a game, has been the framework by which I have analyzed how self-deprecating humor has functioned rhetorically. Although seemingly aggressive and other-disparaging, these theories explain how a rhetor may attain rhetorical benefits by using self-directed humor. Whether to bring oneself down a peg for the benefit of an audience thereby lessening perceived social distance or perceptions of arrogance, or to disparage an individual part of oneself or a past version of oneself to illustrate growth or betterment, the superiority theory of humor can be used to explain how a rhetor can concurrently demean oneself while in actuality achieving greater strength of character or 140 
a stronger rhetorical position. Gruner's (1997) game theory of humor further illustrates both the playful and strategic nature of self-deprecating humor. Following Gruner's tenets of humor as a game which can be won and lost, self-deprecating humor fits as its user "loses" to the audience, while also rhetorically "winning" in some other manner. Thus, as stated previously, self-deprecating humor is tantamount to intentionally losing a game in order to receive a benefit greater than that which would have been received from winning.

Bakhtin's (1984) concept of the carnival as a rhetorical situation in which authority figures are able to, for a time, act incongruently to show how societal conventions generally constrain them to act explains the unique situation of the WHCD as a place where self-deprecating humor becomes appropriate. Because presidents are afforded considerably more latitude for gaiety than otherwise possible outside of the dinners, they are also permitted to make rhetorical appeals in a manner which would likewise be taboo beyond the unique rhetorical realm of the WHCD. This paints selfdeprecating humor as something which is appropriate as a rhetorical strategy in situations in which humor in general would be appropriate. Thus, while self-deprecating humor may be acceptable when used during a situation like the WHCD, it would not be a useful rhetorical strategy when used during a State of the Union address, for example. This is in keeping with the principles of epideictic rhetoric (Aristotle, 2010). As a rhetorical genre, epideictic rhetoric is predicated on praising and blaming, and as Burke (1969) suggests, is playful and artful. Thus, as an epideictic situation recognized as also operating under tenets of Bakhtin's (1984) notion of the carnival, a WHCD is an inherently appropriate place in which self-deprecating humor may be employed. 
As a situation in which self-deprecating humor has become to be expected, each president who speaks at the WHCD is made aware that such humor is not only anticipated, but evidenced by its continued appropriation throughout the years, is rhetorically useful as well. As a consequence, we find that self-deprecation functions politically as a trusty implement in the proverbial rhetorical toolbox alongside other, well-established means of argumentation. That previous instances of self-deprecation being used outside of a WHCD by presidents have been noted (Peters \& Woolley, 1994a; Bruni, 2001; The Commission On Presidential Debates, 2012) only further affirms this fact.

Thus, this analysis positions the rhetorical situation of the carnival as being one in which self-deprecating humor is particularly effective. Since, as established, the success of self-deprecating humor is contingent on the audience understanding the ironic nature of what is being said, the carnival makes such a distinction plain through its association with the incongruence inherent to the situation. Simply put, during a carnivalesque situation, it is understood not to take what is being said literally. This works in concert with the nature of epideictic rhetoric in general, which by its nature is rhetoric which tends to not be assessed as critically by the audience. Consequently, self-deprecating humor is likewise well-suited for rhetorical situations which are epideictic in nature.

Further entrenching the notion that self-deprecating humor is most effective when its nature as a joke is well understood, this analysis recognizes the particular efficacy of such humor when it is used by authority figures. By the nature of their position, combined with the aforementioned rhetorical situation in which self-deprecating humor best functions, it can be said that the humorous nature of self-deprecation is made more 142 
clear when it is used by those in authoritative roles. That this is so owes to the previously discussed notion of perceived higher self-esteem equating with an understanding that the intent of the use of self-deprecating humor is not for pity or a cry for affirmation, but merely a light-hearted show of goodwill at one's own expense. When used by a rhetor that does not appear to hold him or herself to a high regard, self-deprecating humor can thus backfire as a rhetorical strategy, as it undermines speaker ethos.

Contrasted with overtly other-directed disparaging humor, the analyses have established how self-deprecating humor is unique in that it may be employed to attack others or their arguments while still being able to maintain goodwill. In this, selfdeprecating jokes at one's own expense can afford a rhetor the ability to indict others in a way which is significantly more rhetorically "palatable." By their nature, authority figures have a deal of power relative to their audience, putting them in a situation in which their application of other-disparaging jokes could make them appear overly aggressive, or like a bully. Thus, the impact of other-disparaging jokes like those used by popular political comedians Jon Stewart and Stephen Colbert would likely be perceived as being in poor taste, necessitating a self-deprecating twinge to take the "bite" out of the otherwise other-disparaging jokes.

In terms of presidential rhetoric, this conclusion speaks to the value of an otherwise unconventional means of persuasion to combat criticism, issue arguments, and bolster an image. Given the litany of issues these presidents faced when using selfdeprecating humor, we find that the use of such humor can be an effective strategy to deal with the gamut of controversy a president will inevitably face. The findings provided by this analysis also reassert the notion that successful rhetoric entails not just taking into 
consideration what to say, but also that recognizing that the situation in which it is practiced is equally important. As each WHCD operates under a special rhetorical situation; it is understood that what serves as appropriate discourse and that which is offlimits is different than in most any other situation.

\section{Limitations of the Analysis}

That the self-deprecating humor analyzed in this thesis was used by figures in a very unique position of authority, when speaking to a very specific audience, during an unquestionably exceptional rhetorical situation in which traditional roles and expectations were subverted should not paint the use of self-deprecating humor as a rhetorical strategy as one helpful only to presidents of the United States during White House Correspondents' Dinners. On the contrary, I submit that this genre of humor may in fact be used by authoritative rhetors of all stripes, in a host of situations and contexts, to achieve similar results. Nevertheless, the fact that all instances of self-deprecation I have analyzed were delivered in a largely narrow context is problematic in ascertaining how its use functions rhetorically in a more general manner.

Owing to the dearth of texts available in which self-deprecating humor is used makes the WHCD one of the few consistent situations in which its employment may be analyzed. This, then, provides a limited scope in which to view self-deprecating humor by other kinds of authority figures. Although certainly part of many comedians' regular repertoires of humor styles, when used in a more serious, rhetorical setting by equally solemn individuals, self-deprecation is not as abundant in available texts. Moreover, the WHCD serves as one of the few situations in which such humor is consistently used, 
making it an excellent text to analyze and to observe its multifaceted rhetorical nature, but also one relatively unique compared to more isolated uses of this kind of wit.

Because I have identified the WHCD as functioning like the carnival (Bakhtin, 1984), this analysis neglects to consider how self-deprecating humor functions rhetorically when not employed in such a context. Thus, the question is raised: does selfdeprecation still work if it is used in a situation in which the carnivalesque is not established? Further, the nature of the WHCD audience must also be taken into consideration as a variable which might also affect its use. That each of the presidents largely made self-deprecating reference to media criticism speaks largely to the fact that the audience itself was made up of members of the media - this, of course, is the nature of the event. Thus, it is unclear if and how the subject matter and self-deprecating themes would vary when such humor is used for the benefit of a different audience.

\section{Areas for Future Research}

As a consequence of the rhetorical strategic benefits explicated, I posit that selfdeprecating humor, a style of wit scarcely considered in academic literature, should be studied further both holistically and under the purview of rhetorical discourse. As established, self-deprecating humor functions in congruence with already firmlyestablished theories of humor which have received considerable scholarship. This fact suggests that such humor is more meritorious of further research as an addition to humor scholarship which already exists than its paucity of coverage implies. Understood that self-deprecation is not merely a phenomenon observed in the servile and insecure, selfdeprecating humor should now be recognized for the rhetorical value its use during the analyzed WHCDs implies. 
This thesis has considered self-deprecating humor used by rhetors through an analysis of speech transcripts. Other than instances in which the chosen speakers employed visual humor, only the text of the transcripts from the speeches were analyzed. In future studies, videos of the speeches which could convey non-verbal facets of selfdeprecating humor should also be considered when assessing its use. Epideictic rhetoric is likewise approached in a context which has until now been scarcely covered-that pertaining to humorous oration as a means of persuasion which, by its nature as rhetoric given in a context in which the audience will inherently be less critical, can function in a more "covert" manner than that given in other contexts. As a consequence, persuasion attempts made in an epideictic situation through the use of humor is a genre of study which merits further analysis.

Considering self-deprecation beyond the relatively narrow purview of political discourse, authority figures of other stripes can make use of its persuasive abilities. Organizational communication, health communication, and classroom communication in particular stand as areas in which the use of self-deprecating humor may be useful to navigate the authority-subordinate relationships which inherently ensue. As a consequence, further research into the application of self-deprecation in those fields of study would serve to enhance both their respective areas of research, as well as that of the subject of self-deprecating humor as well.

Self-deprecating humor may be assessed in further rhetorical contexts or through quantitative assessments of its perceived impact on speaker credibility. Perhaps because of its reputation as a negative kind of humor which is perceived to be inherently harmful to character and credibility, both rhetorical and quantitative research on its effect on 
speaker credibility has thus far lacking. Further research into the domain of selfdeprecating humor as a means of reputation management, image repair, or a method of increasing speaker immediacy or lessening audience apprehension would benefit study of the genre of humor greatly.

\section{Conclusion}

The use of self-deprecating humor by those in a position of authority represents a major contradiction. Most public speaking texts impel their readers to stay away from self-deprecating humor. Such humor, they argue, will only draw attention to flaws, suggests low self-esteem, discredits any arguments made, and lowers the overall perceptions of speaker credibility. Beyond the realm of oratory, self-deprecating humor is recognized as being a hallmark of the depressed and insecure. Thus, no speaker should use such humor in a context in which humor is not already used, least of which a speaker in a position of power.

Yet speakers in the role of an authority do use such humor, and as has been established, often to great effect. The recognition of this contradiction thus represents a rejection of this conventional wisdom, an attack, I hope, which will serve to encourage further analysis and assessment of how rhetors may best use self-deprecating humor as a means of persuasion. Beyond the White House Correspondents' Dinner as a rhetorical situation, beyond the realm of politics, and beyond even presidential communication, self-deprecation is used by authority figures from all backgrounds, in a wide range of situations. Thus, a veritable cornucopia of situations in which self-deprecation is used in manners already established are availed to scholars, ripe for study and analysis. The ubiquity of self-deprecating humor in the face of morés suggesting its taboo nature 
speaks to its position as a subject well worth assessing. This analysis, then, represents what should be the beginning of what will be a continued effort to discuss the rhetorical powder keg that is self-deprecating humor. 


\section{REFERENCES}

1984 electoral college. (2013). Retrieved from http://www.realclearpolitics.com/epolls/1984/president/1984_elections_electoral_ college_map.html

Amossy, R. (2001). Ethos at the crossroads of disciplines: Rhetoric, pragmatics, sociology. Poetics Today, 22(1), 1-23.

Applebome, P. (1992, March 08). Bill Clinton's uncertain journey. Retrieved from http://www.nytimes.com/1992/03/08/magazine/bill-clinton-s-uncertainjourney.html? $\mathrm{src}=$ pm\&pagewanted $=2 \&$ pagewanted $=$ print

Aristotle, Ross (Editor), W. D., \& Rhys Roberts (Trans), W. (2010). Rhetoric. (1 ed.). New York, NY: Cosimo Classics.

Arotsky, D. (2004, May 07). Singer authors book on the role of ethics in Bush presidency. Retrieved from http://dailyprincetonian.com/news/2004/05/singerauthors-book-on-the-role-of-ethics-in-bush-presidency/

Associated Press. (1984, March 28). Gov. Lamm asserts elderly, if very ill, have 'duty to die'. The New York Times. Retrieved from http://www.nytimes.com/1984/03/29/us/gov-lamm-asserts-elderly-if-very-illhave-duty-to-die.html

Associated Press. (1985, January 08). Reagan and Bush are re-elected in a landslide, 525 votes to 13. Retrieved from http://www.nytimes.com/1985/01/08/us/reagan-andbush-are-re-elected-in-a-landslide-525-votes-to-13.html

Associated Press. (2002, May 05). Briefly, White House is all Comedy Central, no C$S P A N$. Retrieved from http://articles.latimes.com/2002/may/05/nation/na-roast5

Associated Press. (2005, August 03). Bush's ranch serves down-home diplomacy. Retrieved from http://usatoday30.usatoday.com/news/washington/2005-08-03bush-ranch_x.htm

Associated Press. (2008, March 12). Today on the presidential campaign trail. Retrieved from

http://www.foxnews.com/printer_friendly_wires/2008Mar12/0,4675,2008RaceRu 
ndown,00.html

Badarneh, Muhammad A. (2011). Carnivalesque politics: A Bakhtinian case study of contemporary Arab political humor. Humor: International Journal of Humor Research, 24(3), 305-327.

Baker, G. (2001, April 28). COMMENT \& ANALYSIS: An early victory: George W. Bush has had setbacks in his first 100 days as president but his success in tackling crucial obstacles. Financial Times, p. 10.

Bakhtin, M. M. (1984). Rabelais and his World. Bloomington: Indiana University Press.

BBC. (n.d.). 1992: Clinton beats Bush to the White House. Retrieved from http://news.bbc.co.uk/onthisday/hi/dates/stories/november/4/newsid_3659000/365 9498.stm

BBC. (2001, April 13). Chinese jet 'snapped in two'. Retrieved from http://news.bbc.co.uk/2/hi/asia-pacific/1275404.stm

Beam, C. (2010, April 30). How political speechwriters do comedy. Retrieved from http://www.slate.com/articles/news_and_politics/politics/2010/04/a_guy_walks_i nto_an_oval_office.html

Becker, A. B. (2012). Comedy Types and Political Campaigns: The Differential Influence of Other-Directed Hostile Humor and Self-Ridicule on Candidate Evaluations. Mass Communication \& Society, 15(6), 791-812. doi:10.1080/15205436.2011.628431

Bekelja Wanzer, M., Bainbridge Frymier, A., Wojtaszczyk, A. M., \& Smith, T. (2006). Appropriate and inappropriate uses of humor by teachers. Communication Education, 55(2), 178-196.

Biebel, B. (2010). Standing Up for Comedy: Kenneth Burke and The Office. KB Journal, $7(1)$

Billig, M. (2005). Laughter and ridicule: towards a social critique of humour. London: Sage.

Bippus, A. (2007). Factors predicting the perceived effectiveness of politicians' use of humor during a debate. Humor: International Journal Of Humor Research, 20(2), 105-121. doi:10.1515/HUMOR.2007.006

Bitzer, L. F. (1992). The Rhetorical Situation. Philosophy \& Rhetoric, 251-14.

Booth, W. C. (2007). A rhetoric of irony. Chicago, Ill.: The University of Chicago Press. 
Boyd, G. M. (1986, April 15). Reagan is harsh over contra aid. New York Times, p. A6.

Brode, D. S. (1986, March 26). Reagan's spring slump. The Washington Post, p. A19.

Brooks, M. (Director) (1967). The producers [Theater].

Brown, A. (2012, November 09). Justin Welby introduces himself with self-deprecation and a hint of steel. Retrieved from http://www.theguardian.com/uk/2012/nov/09/justin-welby-self-deprecation-steel

Bruni, F. (2000, August 12). The 2000 campaign: The Texas governor; Bush calls on Gore to denounce Clinton affair . Retrieved from http://www.nytimes.com/2000/08/12/us/2000-campaign-texas-governor-bushcalls-gore-denounce-clinton-affair.html

Bruni, F. (2001, April 01). Word for word/Bushspeak; the president's sense of humor has also been misunderestimated. The New York Times. Retrieved from http://www.nytimes.com/2001/04/01/weekinreview/word-for-word-bushspeakpresident-s-sense-humor-has-also-been-misunderestimated.html

Bumiller, E. (2004, January 12). Bush gets 'vision thing' and embraces big risks. Retrieved from http://www.nytimes.com/2004/01/12/politics/12LETT.html?ex=1389243600\&en $=72 \mathrm{a} 6159980245012 \& \mathrm{ei}=5007 \&$ partner $=$ USERLAND

Burgchardt, C. R. (2000). Readings in rhetorical criticism. State College, Pa: Strata.

Burke, K. (1969). A rhetoric of motives. Berkeley: University of California Press.

Bush, G. W. Office of the Federal Register, National Archives and Records Administration. (2001a). Weekly compilation of presidential documents volume 37, issue 18 (may 7, 2001) (AE 2.109; GS 4.114). Washington, D.C.: Office of the Federal Register, National Archives and Records Administration.

Bush, G. W. (2001b, September 17). America's new war: President Bush talks with reporters at pentagon. Retrieved from http://transcripts.cnn.com/TRANSCRIPTS/0109/17/se.09.html

Bush, G. W., \& Weisberg, J. (2001). George W. Bushisms: The Slate book of the accidental wit and wisdom of our forty-third president. New York: Fireside.

Bush, G. W. (2002, March 15). President Bush speaks in Fayettville, North Carolina. Retrieved from http://transcripts.cnn.com/TRANSCRIPTS/0203/15/se.01.html 
Bush, G. W. (2003, March 19). Full text: George Bush's address on the start of war. Retrieved from http://www.theguardian.com/world/2003/mar/20/iraq.georgebush

Bush, G. W. (2010). Decision points. New York: Crown Publishers.

Cannon, C. M. (2011, January 27). The Challenger disaster and President Reagan's gift to a grieving nation. Retrieved from http://www.politicsdaily.com/2011/01/27/the-challenger-disaster-and-presidentreagans-gift-to-a-grievi/

Chang, M., \& Gruner, C. R. (1981). Audience reaction to self-disparaging humor. Southern Speech Communication Journal, 46(4), 419-426.

Chapman, A. J., \& Foot, H. C. (1976). Humour and laughter: Theory, research, and applications. London: Wiley.

Clinton, B. (Performer) (1992). In Choose or Lose: Facing the Future with Bill Clinton. MTV.

Clinton, B. (2000, April 29). 2000 White House Correspondents Dinner. Retrieved from http://politicalhumor.about.com/library/blclintonwhca.htm

Clinton, B. (2004). My life. New York: Alfred A. Knopf.

Colleta, L. (2009). Political Satire and Postmodern Irony in the Age of Stephen Colbert and Jon Stewart. Journal Of Popular Culture, 42(5), 856-874. doi:10.1111/j.1540-5931.2009.00711.x

Condit, C. (1985). The Functions of Epideictic: The Boston Massacre Orations as Exemplar. Communication Quarterly, 33(4), 284-298.

Congressional Quarterly, inc. (1985). Reagan, the next four years. Washington, D.C: Congressional Quarterly Inc.

Couch, A. (2011, February 05). Reagan's 100th birthday: 10 defining moments. Retrieved from http://www.csmonitor.com/USA/2011/0205/

Reagan-s-100th-birthday-10-defining-moments/The-Challenger-disaster-Jan.-281986

Culberson, R. (2013, May 13). Humor, leadership and the White House Correspondents Dinner. Retrieved from http://www.huffingtonpost.com/ron-culberson-msw-csp/humor-leadership-andthe-_b_3209273.html 
Dahrendorf, R. (1959). Class and class conflict in industrial society. In D. B. Gursky (Ed.), Social Stratification: Class, Race, and Gender in Sociological Perspective (3rd ed., pp. 91-97). Philadelphia, PA: Westview Press.

Davidson, I. (1986, April 14). how not to deal with the terrorists; foreign affairs. Financial Times

De Crespigny A., \& Wertheimer, A. (2010). Power, authority, justice \& rights: Studies in political obligations. New Brunswick, NJ: AldineTransaction.

Deckers, L., \& Kizer, P. (1975). Humor and the incongruity hypothesis. The Journal of Psychology, 90(2), 215-218.

deprecation. (n.d.). Dictionary.com Unabridged. Retrieved September 29, 2013, from

Dewberry, D. R., \& Fox, R. (2012). Easy as 1, 2, 3: Rick Perry and self-deprecation as image restoration. Journal of Contemporary Rhetoric, 2(1), 1-10.

Duarte, N. (2012). HBR guide to persuasive presentations. Boston, Mass: Harvard Business Review Press.

Edwards , J. (2011, April 27). White House Correspondents' Dinner: 25 memorable moments. Retrieved from http:/www.nationaljournal.com/white-housecorrespondents-dinner-25-memorable-moments-20110427

Edwards, L. (2005). The essential Ronald Reagan: A profile in courage, justice, and wisdom. Lanham: Rowman \& Littlefield Publishers.

Ewin, R. E. (2001). Hobbes on laughter. The Philosophical Quarterly, 51(202), 29-40.

Fastenberg, D. (2010, July 29). Boxers or briefs? Clinton answers. Retrieved from http://content.time.com/time/specials/packages/article/0,28804,2007228_2007230 _2007258,00.html

Ferguson, M. A., \& Ford, T. E. (2008). Disparagement humor: A theoretical and empirical review of psychoanalytic, superiority, and social identity theories. Humor: International Journal Of Humor Research, 21(3), 283-312. doi:10.1515/HUMOR.2008.014

Fortenbaugh, W. W. (1992). Aristotle on Persuasion Through Character. Rhetorica: A Journal Of The History Of Rhetoric, (3), 207. doi:10.1525/rh.1992.10.3.207 
Foss, S. K. (2009). Rhetorical criticism: Exploration and practice. Long Grove, Ill: Waveland Press.

Francis, L. E. (1994). Laughter, the best mediation: Humor as emotion management in interaction. Symbolic Interaction, 17(2), 147-163.

Frymier, A. B., \& Houser, M. L. (2012). The influence of teacher humor on student learning. In R. L. DiCioccio (Ed.), Humor Communication: Theory, Impact, and Outcomes (pp. 215-227). Dubuque, IA: Kendall Hunt.

Gamble, D. (2004, June 07). funnyman Reagan humor glowed from his soul.. Retrieved from http://old.nationalreview.com/comment/gamble200406070851.asp

Geyelin, P. (1985, February 12). The royal style. The Washington Post, p. A21.

Gorham, J., \& Christophel, D. M. (1990). The relationship of teachers' use of humor in the classroom to immediacy and student learning. Communication Education, $39(1), 46-62$.

Greengross, G. \& Miller, G.F. (2008). Dissing oneself versus dissing rivals: Effects of status, personality, and sex on the short-term and long-term attractiveness of selfdeprecating and other-deprecating humor. Evolutionary Psychology, 6, 393-408.

Gruner, C. R. (1967). Speaker ethos, self-disparaging humor, and perceived "sense of humor.". Journal of Communication, 17(3), 228-233.

Gruner, C. R. (1985). ADVICE TO THE BEGINNING SPEAKER ON USING HUMOR - WHAT THE RESEARCH TELLS US. Communication Education, 34(2), 142.

Gruner, C. R. (1997). The game of humor: A comprehensive theory of why we laugh. New Brunswick, N.J: Transaction Publishers.

Hackman, M. Z. (1988). Audience Reactions to the Use of Direct and Personal Disparaging Humor in Informative Public Address. Communication Research Reports, 5(2), 126-130.

History of the whca. (2013). Retrieved from http://www.whca.net/

Hodgart, M. J. C. (1969). Satire. New York: McGraw-Hill.

Hofstede, G. (1980), Culture's Consequences: International Differences in Work-related Values Beverly Hills, CA: Sage.

Hoption, C., Barling, J., \& Turner, N. (2013). "It's not you, it's me": transformational 
leadership and self-deprecating humor. Leadership \& Organization Development Journal, 34(1), 4. doi:10.1108/01437731311289947

Hornick, E. (2011, February 06). Reagan's myth has grown over time. Retrieved from http://www.cnn.com/2011/POLITICS/02/04/reagan.legacy/

Ifill, G. (1994, April 23). The Whitewater affair: The overview; Hillary Clinton takes questions on whitewater. The New York Times. Retrieved from http://www.nytimes.com/1994/04/23/us/the-whitewater-affair-the-overviewhillary-clinton-takes-questions-on-whitewater.html

In Weiler, M., \& Pearce, W. B. (1992). Reagan and public discourse in America. Tuscaloosa, Ala: University of Alabama.

Janes, L. M., \& Olson, J. M. (2010). Is it you or is it me? Contrasting effects of ridicule targeting other people versus the self. Europe's Journal of Psychology, 6(3), 4670.

Kahn, S. (1975). Why and how we laugh. New York: Philosophical Library.

Knapp, T. G. (2011). The Daily Show and rhetoric: Arguments, issues, and strategies. Lanham, Md: Lexington Books.

Korobkin, D. (1988), "Humor in the Classroom: Considerations and Strategies," College Teaching, 36, 154-158.

Lafferty, E. (2001, April 28). U.S. got more than it bargained for with the conservative Texan the overriding impression of the Bush administration after 100 days is that the new president is driven by ideology, suggests Elaine Lafferty. The Irish Times, p. 13.

Lee, C. E. (2009, March 05). Obama's safety net: the teleprompter. Retrieved from http://www.politico.com/news/stories/0309/19663.html

Lefcourt, H.M. (2001). Humor: the psychology of living buoyantly. New York: Kluwer Academic/Plenum Publishers.

Lynch, O. W. (2012). Bucket humor: The significant role of humor within organizational culture. In R. L. DiCioccio (Ed.), Humor Communication: Theory, Impact, and Outcomes (1 ed., pp. 175-188). Dubuque, IA: Kendall Hunt.

Lundy, D.E., Tan, J., \& Cunningham, M.R. (1998) Heterosexual romantic preferences: The importance of humor and physical attractiveness for different types of relationships. Personal Relationships, 5, 311-325. 
Magee, J C. \& Smith, P. K. (2013). The social distance theory of power. Personality and social psychology review, 17(2), 158.

Markiewicz, D. (1974). Effects of humor on persuasion. Sociometry, 407-422.

Martin, R. A. (2007). The psychology of humor: An integrative approach. Amsterdam: Elsevier Academic Press.

McGhee, P. E., \& Goldstein, J. H. (1983). Handbook of humor research (Vols. 1-2). New York: Springer-Verlag.

Mendell, D. (2007). Obama: From promise to power. New York: Harper CollinsPub.

Meyer, J. C. (2000). "Humour as a double-edged sword: Four functions of humour in communication." Communication Theory, 10, 310-331.

Meyer, J. C. (2012). Humor functions in communication. In R. L. DiCioccio (Ed.), Humor Communication: Theory, Impact, and Outcomes (pp. 21-33). Dubuque, IA: Kendall Hunt.

Monosson, E. (2010, March 23). Biological homeostasis. Retrieved from http:/www.eoearth.org/view/article/150655/

Monro, D. H. (1963). Argument of laughter. Notre Dame: University of Notre Dame Press.

Morrison, T. (1998, October 05). Comment. Retrieved from http://www.newyorker.com/archive/1998/10/05/1998_10_05_031_TNY_LIBRY_ 000016504? currentPage $=$ all

Morreall, John. (1989). “Enjoying incongruity.” HUMOR: International Journal of Humor Research, 2, pp. 1-18.

Morreall, J. (1983). Taking laughter seriously. Albany: State University of New York.

Nerhardt, G. (1976). Incongruity and funniness: Towards a new descriptive model. In J. C. Chapman \& C. F. Foot (Eds.), Humour and Laughter: Theory, Research and Applications (pp. 55-62). Great Britain: John Wiley \& Sons.

Newport, F. (2001, January 04). Clinton's job approval legacy. Retrieved from http://www.gallup.com/poll/4657/clintons-job-approval-legacy.aspx

Norman, H. (1982). Laughing: A psychology of humor. Ithaca, NY: Cornell University 
Press.

Obama, B. (2006). The audacity of hope: Thoughts on reclaiming the American dream. New York: Crown Publishers.

Obama, B. (2008, August 29). Obama: We are better than these last eight years. Retrieved from http://www.cnn.com/2008/POLITICS/08/28/obama.transcript/index.html?iref=ne wssearch

Obama, B. (2013, April 27). Remarks by the president at the White House Correspondents' Association Dinner. Retrieved from http://www.whitehouse.gov/the-press-office/2013/04/27/remarks-president-whitehouse-correspondents-association-dinner

Paley Center for Media. (2011). The Paley Center's countdown to the 70th anniversary of television. Retrieved from http://www.paleycenter.org/p-70-tv-countdown-10

PBS. (2000). Debating our destiny: The 1984 debates. Retrieved from http://www.pbs.org/newshour/debatingourdestiny/dod/1984-broadcast.html

Perloff, R. M. (1998). Political communication: Politics, press, and public in America. Mahwah, N.J: Erlbaum.

Perloff, R. M. (2013). The dynamics of persuasion: Communication and attitudes in the 21 st century.

Peters, G., \& Woodley, J. T. (1994a, April 12). Remarks at the Radio and Television Correspondents Dinner. Retrieved from http://www.presidency.ucsb.edu/ws/?pid=49951

Pokorny, G. F., \& Gruner, C. R. (1969). An Experimental Study of the Effect of Satire Used as Support in a Persuasive Speech. Western Speech, 33(3), 204-211.

Priego-Valverde, B. (n.d.). Self-disparaging humor in conversations: a brief survey of a complex phenomenon usually considered as obvious. (Informally published manuscript, Université de Provence) Retrieved from www.lpl.univaix.fr/ fulltext/3421.pdf

Purzycki, B. (2011). Humor as Violation and Deprecation: A Cognitive Anthropological Account. Journal Of Cognition \& Culture, 11(1/2), 217-230. doi:10.1163/156853711X568752

Sampson, A. C., \& Hempelmann, C. F. (2011). Humor with backgrounded incongruity: Does more required suspension of disbelief affect humor perception?. Humor: 
International Journal Of Humor Research, 24(2), 167-185.

doi:10.1515/HUMR.2011.011

Spencer, H. (1911). Essays on education and kindred subjects. (pp. 162-167). Great Britain: Aldine Press.

Rancer, A. S., \& Graham, E. E. (2012). Theories of humor. In R. L. DiCioccio (Ed.), Humor Communication: Theory, Impact, and Outcomes (1 ed., pp. 3-20). Dubuque, IA: Kendall Hunt.

Reagan-Bush '84. (1984). Morning in America [Television commercial]. Available from http://www.youtube.com/watch?v=EU-IBF8nwSY

Reagan, R. (1986a, April 15). Reagan: 'we have done what we had to do'. The Washington Post, p. A23.

Reagan, R. (1986b, April 14). Address to the nation on the United States air strike against Libya. Retrieved from http://www.presidency.ucsb.edu/ws/index.php?pid=37131\&st=libya\&st1=

Reagan, R. (1990). An American life. New York: Simon and Schuster.

Real Beer Media. (2000, October 17). Bush gets 'beer vote'. Retrieved from http://www.realbeer.com/news/articles/news-001395.php

Riggins, S. H. (1997). The language and politics of exclusion: Others in discourse. Thousand Oaks, Calif: Sage Publications.

Roemer, T. (2006, April 29). Enough already. The New York Times, p. A2.

Ruimy, J. (1986, April 15). Pm modifies stance on U.S. bombing raid. Toronto Star, p. A1.

Saha, D. (2006). Sociology of social stratification. New Delhi, India: Global Vision Pub. House.

Schulman, K. (2011, May 01). "the president's speech" at the white house correspondents' dinner. Retrieved from http://www.whitehouse.gov/blog/2011/05/01/president-s-speech-white-housecorrespondents-dinner

Schutz, C. E. (1977). Political humor: From Aristophanes to Sam Ervin. Rutherford N.J.: Fairleigh Dickinson University Press. 
Sheffield, G. (2006, April 30). Bush lampoons press, self at wh correspondents dinner. Retrieved from http://newsbusters.org/node/5151

Shields, C. (2012). The Oxford handbook of Aristotle. Oxford, England: Oxford University Press.

Shirley, C. (2005). Reagan's revolution: The untold story of the campaign that started it all. Nashville, Tenn: Nelson Current.

Sillars, M. O., \& Gronbeck, B. E. (2001). Communication criticism: Rhetoric, social codes, cultural studies. Prospect Heights, Ill: Waveland Press.

Smith, S. A. (1993). Humor as rhetoric and cultural argument. Journal of American Culture, 16(2), 51-64.

Stocking, S.H. \& Zillmann, D. (1976). Effects of humorous disparagement of Self, friend, and enemy. Psychological Reports, 39, 455-461.

Strecker, E. (2013, August 06). Lindsay Lohan on 'Chelsea Lately' is giggly and selfdeprecating. Retrieved from http://www.cnn.com/2013/08/06/showbiz/tv/lohanchelsea-lately-ew/index.html

Sullivan, P. (2007, August 19). Reagan image-maker changed American politics. Retrieved from http://www.washingtonpost.com/wpdyn/content/article/2007/08/18/AR2007081800587.html?sub=AR

The Commission On Presidential Debates (2012). October 21, 1984 debate transcript. Retrieved from http://www.debates.org/index.php?page=october-21-1984-debatetranscript

The Smoking Gun. (2006, February 16). Texas cops release cheney shooting report. Retrieved from http://www.thesmokinggun.com/documents/crime/texas-copsrelease-cheney-shooting-report

Tillman, J. (2012, August 30). Gov. Scott Walker and a self-deprecating zinger. Retrieved from http://www.tampabay.com/blogs/the-buzz-floridapolitics/content/gov-scott-walker-and-self-deprecating-zinger

Wallace, K. (2001, April 25). Bush pledges whatever it takes to defend Taiwan. Retrieved from http://edition.cnn.com/2001/ALLPOLITICS/04/24/bush.taiwan.abc/

Wanzer, M., Frymier, A., Wojtaszczyk, A. M., \& Smith, T. (2006). Appropriate and Inappropriate Uses of Humor by Teachers. Communication Education, 55(2), 178-196. doi:10.1080/03634520600566132 
Weiner, T. J. (2004, May 15). Blueprint for victory. Retrieved from http://americasfuture.org/doublethink/2004/05/blueprint-for-victory/

Weinraub, B. (1984, February 22). Mondale accuses president of 'leadership by amnesia'. Retrieved from http://www.nytimes.com/1984/02/22/us/mondale-accusespresident-of-leadership-by-amnesia.html

Weresh, M. H. (2012). Morality, trust, and illusion: Ethos as relationship. Legal Communication \& Rhetoric: JALWD, 9(1), 229-272.

Westcott, K. (2003, June 06). Bush revels in cowboy speak. Retrieved from http://news.bbc.co.uk/2/hi/americas/2968176.stm

WHCA. (2014). Whca? 2013-2014 officers and board. Retrieved from http://www.whca.net/officers.htm

White, E. B., \& White, K. S. A. (1941). A subtreasury of American humor. New York: Coward-McCann, inc.

Whitehead Jr, J. L. (1968). Factors of source credibility. Quarterly Journal of Speech, 54(1), 59-63.

White House Correspondents' Association (Producer). (2000, April 29). Clinton Parody [Video file]. Retrieved from http://www.c-span.org/video/?c4305109/clintonparody

Williams, J. (1984, March 11). Broadcasts called 'negative'; Reagan hits tv's economic coverage. The Washington Post, p. A6.

Woolley, J. T., \& Peters, G. (1984, April 13). Remarks at the annual dinner of the White House Correspondents Association . Retrieved from http://www.presidency.ucsb.edu/ws/index.php?pid=39776

Woolley, J. T., \& Peters, G. (1986, April 17). Remarks at the annual White House Correspondents Dinner . Retrieved from http://www.presidency.ucsb.edu/ws/index.php?pid=37150

Woolley, J. T., \& Peters, G. (1994a, April 12). Remarks at the Radio and Television Correspondents Dinner. Retrieved from http://www.presidency.ucsb.edu/ws/?pid=49951

Woolley, J. T., \& Peters, G. (1994b, April 23). Remarks at the annual White House Correspondents Dinner. Retrieved from http://www.presidency.ucsb.edu/ws/index.php?pid=50040 
Zeytinoglu , C. (2008). Philosophy of epideictic rhetoric. The International Journal of the Humanities, 6(2), 17-25.

Zhang, Y., \& Begley, T. M. (2011). Power distance and its moderating impact on empowerment and team participation. International Journal Of Human Resource Management, 22(17), 3601-3617. doi:10.1080/09585192.2011.560877 